\title{
Materiais Obturadores de Canais Radiculares de Dentes \\ Decíduos: Avaliação da Atividade Antibacteriana IN VItro e da \\ Compatibilidade TeCidual IN VIVO
}

Tese apresentada à Faculdade de

Odontologia de Ribeirão Preto da

Universidade de São Paulo, para obtenção

do Título de Doutor junto ao Programa de Pós-Graduação em Odontopediatria.

Orientadora: Prof ${ }^{a}$. Dra ${ }^{a}$ Sada Assed

Ribeirão Preto

2008 
Queiroz, Alexandra Mussolino,

Materiais obturadores de canais radiculares de dentes decíduos: avaliação da atividade antibacteriana in vitro e da compatibilidade tecidual in vivo. Ribeirão Preto, 2008.

118 p. : il. ; $30 \mathrm{~cm}$

Tese de Doutorado, apresentada à Faculdade de Odontologia de Ribeirão Preto/USP. Área de concentração: Odontopediatria.

Orientadora: Sada Assed.

1. Calen ${ }^{\circledR}$. 2. Sealapex ${ }^{\circledR}$. 3. EndoREZ ${ }^{\mathrm{TM}}$. 4. Óxido de zinco e eugenol. 5. Atividade antibacteriana. 6. Biocompatibilidade. 


\title{
Materiais Obturadores de Canais Radiculares de Dentes Decíduos: Avaliação da Atividade Antibacteriana IN VItroe da Compatibilidade Tecidual in vivo
}

\author{
Tese apresentada à Faculdade de Odontologia \\ de Ribeirão Preto da Universidade de São Paulo, \\ para obtenção do Título de Doutor junto ao \\ Programa de Pós-Graduação em \\ Odontopediatria.
}

Data da defesa:

\section{Banca Examinadora}

Prof. Dr.

Julgamento: Assinatura:

Prof. Dr.

Julgamento: Assinatura:

Prof. Dr.

Julgamento: Assinatura:

Prof. Dr.

Julgamento: Assinatura:

Prof. Dr.

Julgamento: Assinatura: 


\section{Dedico esse Trabalho}

Ao meu pai, Dávio Queiroz de Souza, grande homem, dedicado à família e ao trabalho, que nos transmitiu amor e segurança. Obrigada pelo seu apoio incondicional sempre!

Ao meu amor Edmundo Octávio Raspanti, homem integro, humanitário e idealista. Viver ao seu lado é doce. Obrigada por chegar!

Ao meu irmão Márcio Mussolino de Queiroz, sempre sensato e educado, obrigada.

À minha mãe, Marinês Mussolino de Queiroz, por seu amor, espontaneidade e alegria. Obrigada por estar sempre por perto!

Aos meus filhos, João e Fran, meninos doces e companheiros, tão maduros e corajosos. Amo vocês, obrigada por existirem!

À Si e à Karen, meus braços direito e esquerdo, obrigada pela dedicação e por todo o afeto.

À Sofia, Enzo e Dinda, obrigada pelo carinho e apoio. 


\section{Agradecimentos}

À minha orientadora, Profa. Dra. Sada Assed, professora do Departamento de Clínica Infantil, Odontologia Preventiva e Social da Faculdade de Odontologia de Ribeirão Preto/USP, exemplo de coragem, capacidade de trabalho e amor à vida. Agradeço o carinho e apoio a mim dedicado, durante todos esses anos.

À Profa. Dra. Lea Assed Bezerra da silva, professora do Departamento de Clínica Infantil, Odontologia Preventiva e Social da Faculdade de Odontologia de Ribeirão Preto/USP, obrigada pelos ensinamentos transmitidos, pelo exemplo de dedicação e objetividade.

Ao Prof. Dr. Paulo Nelson-Filho, professor do Departamento de Clínica Infantil, Odontologia Preventiva e Social da Faculdade de Odontologia de Ribeirão Preto/USP, meu amigo, desde o curso de Graduação, e mestre incansável, sempre entusiasmado com a possibilidade de ensinar e disposto a ajudar. Sua dedicação e capacidade são incomparâveis. Fica aqui registrada minha grande admiração! Obrigada.

Ao Prof. Dr. Alberto Consolaro, professor do Departamento de Estomatologia da Faculdade de Odontologia de Bauru/USP, grande mestre, dono de uma inteligência brilhante e capacidade de ensino reconhecida por todos, exemplo de amor à profissão. Meus agradecimentos pelos ensinamentos e pelo total apoio na elaboração deste trabalho.

À Profa. Dra. Aldevina Campos de Freitas, professora do Departamento de Clínica Infantil, Odontologia Preventiva e Social da Faculdade de Odontologia de Ribeirão Preto/USP, exemplo de amor ao próximo, dedicação, paciência e educação. Obrigada por tudo.

À Profa. Dra. Izabel Yoko Ito, professora do Departamento de Análises Clínicas, Toxicológicas e Bromatológicas da Faculdade de Ciências Farmacêuticas de Ribeirão Preto/USP, ícone da Microbiologia e exemplo de dedicação ao ensino.

À Gisele Faria, cirurgiã-dentista do Centro de Formação de Recursos Humanos Especializado no Atendimento Odontológico de Pacientes Especiais da Faculdade de Odontologia de Ribeirão Preto/USP, pela disponibilidade de ajudar e pela capacidade. Obrigada.

Ao Prof. Dr. Mărio Roberto Leonardo, professor colaborador do Departamento de Clínica Infantil, Odontologia Preventiva e Social da Faculdade de Odontologia de Ribeirão Preto/USP, obrigada pelos ensinamentos e pelo auxilio na elaboração deste trabalho.

Ás professoras da Disciplina de Odontopediatria do Departamento de Clínica Infantil, Odontologia Preventiva e Social, da Faculdade de Odontologia de Ribeirão Preto/USP, Profa. Dra. Kranya Victoria Diaz Serrano, Profa. Dra. Maria Cristina Borsatto e Profa. Dra. Raquel Assed Bezerra da Silva, obrigada pelo apoio e amizade. 


\title{
Agradecimentos
}

\author{
À Universidade de São Paulo.
}

À Faculdade de Odontologia de Ribeirão Preto/USP.

À Faculdade de Odontologia de Bauru/USP.

À Comissão de Pós-Graduação da Faculdade de Odontologia de Ribeirão Preto/USP, na pessoa da atual Presidente Profa. Dra. Léa Assed Bezerra da Silva, por todo o apoio.

Aos professores da Disciplina de Odontopediatria do Departamento de Clínica Infantil, Odontologia Preventiva e Social, da Faculdade de Odontologia de Ribeirão Preto/USP, Profa. Dra. Sada Assed. Profa. Dra. Aldevina Campos de Freitas, Profa. Dra. Léa Assed Bezerra da Silva, Prof. Dr. Paulo Nelson Filho, Profa. Dra. Kranya Victoria Díaz Serrano, Profa. Dra. Maria Cristina Borsatto, Profa. Dra. Raquel Assed Bezerra da Silva, por toda a atenção e compreensão.

Aos professores da Disciplina de Ortodontia do Departamento de Clínica Infantil, Odontologia Preventiva e Social, da Faculdade de Odontologia de Ribeirão Preto/USP, Prof. Dr. Adilson Thomazinho, Prof. Dr. Tarcisio Lima Ferreira, Profa. Dra. Mírian Aiko Nakane Matsumoto e Profa. Dra. Maria Bernadete Sasso Stuani, pelo apoio e agradável convivência.

À Profa. Dra. Maria Conceição Pereira Saraiva, do Departamento de Clínica Infantil, Odontologia Preventiva e Social, da Faculdade de Odontologia de Ribeirão Preto/USP, pela amizade e interesse.

Aos funcionários do Departamento de Clínica Infantil, Odontologia Preventiva e Social, da Faculdade de Odontologia de Ribeirão Preto/USP, Marco Antônio dos Santos, Micheli Cristina Leite Rovanholo, Fátima Aparecida Jacinto Daniel, Carmo Euripedes Terra Barretto e Renata Aparecida Fernandes, pela agradável convivência e colaboração constante.

Às funcionárias da Secção de Pós-Graduação da Faculdade de Odontologia de Ribeirão Preto/USP, Isabel Cristina Galino Sola e Regiane Cristina Moi Sacilotto, pela dedicação e carinho dispensados a todos os alunos de pós-graduação.

Aos colegas do Curso de Pós-Graduação em Odontopediatria da Faculdade de Odontologia de Ribeirão Preto/USP, Francisco Wanderley Garcia de Paula e Silva, Valéria Pontelli Navarro Tedeschi, Marta Estela Saravia, Maria Angélica Hueb de Menezes Oliveira, Soraia Monique Fiorati Aguiar e Sara Elisa Medina Mattar e Raquel Assed Bezerra da Silva, pela agradável convivência. 
À funcionária Fătima Aparecida Silveira do Laboratório de Patologia da Faculdade de Odontologia de Bauru/USP, pela valiosa colaboração na confecção das lâminas no estudo em subcutâneo de camundongos.

Ao Jülio César de Matos e Clăudia Regina Corrêa de Matos, pela diagramação e impressão desse trabalho.

À todos que, de alguma forma, contribuíram para a concretização dessa pesquisa. 
SE

Rudyard Kipling

Se és capaz de manter tua calma, quando, todo mundo ao redor ía a perdeu e te culpa.

De crer em ti quando estão todos duvidando,

e para esses no entanto achar uma desculpa.

Se és capaz de esperar sem te desesperares, ou, enganado, não mentir ao mentiroso, Ou, sendo odiado, sempre ao ódio te esquivares, e não parecer bom demais, nem pretensioso.

Se és capaz de pensar - sem que a isso só te atires, de sonhar - sem fazer dos sonhos teus senhores.

Se, encontrando a Desgraça e o Triunfo, conseguires, tratar da mesma forma a esses dois impostores.

Se és capaz de sofrer a dor de ver mudadas, em armadilhas as verdades que disseste E as coisas, por que deste a vida estraçal hadas, e refazê-las com o bem pouco que te reste.

Se és capaz de arriscar numa única parada, tudo quanto ganhaste em toda a tua vida. E perder e, ao perder, sem nunca dizer nada, resignado, tornar ao ponto de partida.

De forçar coração, nervos, músculos, tudo, a dar seja o que for que neles ainda existe. E a persistir assim quando, exausto, contudo, resta a vontade em ti, que ainda te ordena: Persiste!

Se és capaz de, entre a plebe, não te corromperes, $e$, entre Reis, não perder a naturalidade. E de amigos, quer bons, quer maus, te defenderes, se a todos podes ser de alguma utilidade.

Se és capaz de dar, segundo por segundo, ao minuto fatal todo valor e brilho.

Tua é a Terra com tudo o que existe no mundo, e - o que ainda é muito mais - és um Homem, meu filho! 


\section{ResUMO}

Queiroz, AM. Materiais Obturadores de Canais Radiculares de Dentes Decíduos: Avaliação da Atividade Antibacteriana in vitro e da Compatibilidade Tecidual in vivo [tese]. Ribeirão Preto: FORP - Universidade de São Paulo; 2008.

Avaliou-se a atividade antibacteriana e a compatibilidade tecidual dos seguintes materiais obturadores de canais radiculares de dentes decíduos: cimento de óxido de zinco e eugenol, pasta Calen ${ }^{\circledR}$ espessada com óxido de zinco, cimento Sealapex ${ }^{\circledR}$ e cimento EndoREZ ${ }^{\mathrm{TM}}$. A atividade antibacteriana foi avaliada in vitro, por meio do teste de difusão em ágar, frente a 5 microrganismos indicadores (Kocuria rizophila, Enterococcus faecalis, Streptococcus mutans, Escherichia coli e Staphylococcus aureus), sendo os resultados submetidos à análise de variância (ANOVA) e ao pósteste de Tukey. A compatibilidade tecidual foi avaliada in vivo, por implantação subcutânea, em camundongos isogênicos BALB/c, de tubos de polietileno contendo os materiais obturadores. Foram efetuadas análises descritiva e semi-quantitativa do fibrosamento e do infiltrado inflamatório e quantitativa da área e maior espessura do tecido reacional granulomatoso. Os resultados foram submetidos à análise estatística por meio dos testes de Kruskal-Wallis, análise de variância (ANOVA) e pós-teste de Tukey. Para todos os testes o nível de significância foi de 5\%. Com relação à atividade antibacteriana, evidenciaram-se diferenças estatisticamente significantes $(p<0,0001)$ entre os halos de inibição ocasionados pelos diferentes materiais, para todos os microrganismos avaliados. A Kocuria rizophila foi inibida mais eficazmente pelo cimento de óxido de zinco e eugenol $(p<0,05)$, enquanto que o Enterococcus faecalis foi inibido mais eficazmente pela pasta Calen ${ }^{\circledR}$ espessada com óxido de zinco $(p<0,05)$. 0 Streptococcus mutans foi inibido pela pasta Calen ${ }^{\circledR}$ espessada com óxido de zinco, cimento Sealapex ${ }^{\circledR}$ e cimento de óxido de zinco e eugenol na mesma intensidade $(p>0,05)$. A Escherichia coli foi inibida mais eficazmente pelo cimento de óxido de zinco e eugenol, seguido pela pasta Calen ${ }^{\circledR}$ espessada com óxido de zinco e pelo cimento Sealapex ${ }^{\circledR}(p<0,05)$. O Staphylococcus aureus foi inibido pela pasta Calen ${ }^{\circledR}$ espessada com óxido de zinco e pelo cimento de óxido de zinco e eugenol na mesma intensidade $(p>0,05)$, e menos intensamente pelo cimento Sealapex ${ }^{\circledR}(p<0,05) .0$ cimento EndoREZ ${ }^{\mathrm{TM}}$ apresentou atividade antibacteriana apenas frente a Kocuria rizophila e ao Staphylococcus aureus. Com relação à compatibilidade tecidual, não observou-se diferença entre os materiais, com relação ao fibrosamento e à maior espessura do tecido reacional granulomatoso $(p>0,05)$. A pasta Calen ${ }^{\circledR}$ espessada com óxido de zinco foi o material que apresentou infiltrado inflamatório de menor intensidade $(p<0,05)$. A área do tecido reacional granulomatoso foi menor para a pasta Calen $^{\circledR}$ espessada com óxido de zinco e para o cimento Sealapex ${ }^{\circledR}(p>0,05)$ em comparação aos cimentos EndoREZ ${ }^{\mathrm{TM}}$ e óxido de zinco e eugenol $(p<0,05)$. Com base nos resultados obtidos nas metodologias empregadas pôde-se concluir que: 1- A atividade antibacteriana, in vitro, em ordem decrescente foi: cimento de óxido de zinco e eugenol, pasta Calen ${ }^{\circledR}$ espessada com óxido de zinco, cimento Sealapex ${ }^{\circledR}$ e cimento EndoREZ ${ }^{\mathrm{TM}} ;$ 2- A pasta Calen $^{\circledR}$ espessada com óxido de zinco foi o material que apresentou a melhor compatibilidade tecidual, seguido pelos cimentos Sealapex ${ }^{\circledR}$ e de óxido de zinco e eugenol. O cimento EndoREZ ${ }^{T M}$ apresentou resposta tecidual insatisfatória.

Palavras-chave: Calen ${ }^{\circledR}$, Sealapex ${ }^{\circledR}$, EndoREZ ${ }^{T M}$, Óxido de zinco e eugenol, Atividade antibacteriana, Biocompatibilidade. 


\begin{abstract}
Queiroz, AM. Root Canal Filling Materials for Primary Teeth: Evaluation of the in vitro Antibacterial Activity and in vivo Tissue Compatibility [thesis]. Ribeirão Preto: FORP Universidade de São Paulo; 2008.
\end{abstract}

This study evaluated the antibacterial activity and tissue compatibility of the following root canal filling materials for primary teeth: zinc oxide and eugenol cement, Calen ${ }^{\circledR}$ paste thickened with zinc oxide, Sealapex ${ }^{\circledR}$ sealer and EndoREZ ${ }^{T M}$ sealer. The antibacterial activity of these materials against 5 indicator microorganisms (Kocuria rizophila, Enterococcus faecalis, Streptococcus mutans, Escherichia coli and Staphylococcus aureus) was evaluated in vitro using the agar diffusion test. The results were analyzed statistically by the analysis of variance (ANOVA) and Tukey's post-hoc test. Tissue compatibility was evaluated in vivo by the implantation of polyethylene tubes containing the root canal filling materials in the subcutaneous tissue of isogenic BALB/C mice. Descriptive and semi-quantitative analyses of the rate of fibrosis and the inflammatory infiltrate were performed, as well as a quantitative analysis of the area and the greater thickness of the granulomatous reactionary tissue. The results were analyzed statistically by the Kruskal-Wallis test, ANOVA and Tukey's post-hoc test. For all tests, the significance level was set at 5\%. Regarding the antibacterial activity, there were statistically significant differences $(p<0.0001)$ among the zones of inhibition of microbial growth produced by the different materials for all target microorganisms. Kocuria rizophila was inhibited more effectively by the zinc oxide and eugenol cement $(\mathrm{p}<0.05)$, while Enterococcus faecalis was inhibited more effectively by the Calen ${ }^{\circledR}$ paste thickened with zinc oxide $(p<0.05)$. Streptococcus mutans was inhibited by the Calen ${ }^{\circledR}$ paste thickened with zinc oxide, Sealapex ${ }^{\circledR}$ sealer and zinc oxide and eugenol cement in the same intensity $(p>0.05)$. Escherichia coli was inhibited more effectively by the zinc oxide and eugenol cement, followed by the Calen ${ }^{\circledR}$ paste thickened with zinc oxide and Sealapex ${ }^{\circledR}$ sealer $(p<0.05)$. Staphylococcus aureus was inhibited by the Calen ${ }^{\circledR}$ paste thickened with zinc oxide and by the zinc oxide and eugenol cement in the same intensity $(p>0.05)$, and was less effectively inhibited by Sealapex ${ }^{\circledR}$ sealer $(p<0.05)$. EndoREZ ${ }^{\mathrm{TM}}$ sealer presented antibacterial activity only against Kocuria rizophila and Staphylococcus aureus. Regarding tissue compatibility, there was no statistically significant difference among the materials with respect to the rate of fibrosis or the greater thickness of the granulomatous reactionary tissue $(p>0.05)$. The Calen ${ }^{\circledR}$ paste thickened with zinc oxide produced the inflammatory infiltrate with lowest intensity of all materials $(p<0.05)$. The area of the granulomatous reactionary tissue was smaller for the Calen ${ }^{\circledR}$ paste thickened with zinc oxide and Sealapex ${ }^{\circledR}$ sealer $(p>0.05)$ compared to EndoREZ ${ }^{\mathrm{TM}}$ sealer and the zinc oxide and eugenol cement $(p<0.05)$. Based on the results obtained with the methodologies employed in the present study, it may be concluded that: 1 - The in vitro antibacterial activity in a decreasing order was: zinc oxide and eugenol cement, Calen ${ }^{\circledR}$ paste thickened with zinc oxide, Sealapex ${ }^{\circledR}$ sealer and EndoREZ ${ }^{\text {TM }}$ sealer; 2 - The in vivo tissue compatibility in a decreasing order was: Calen ${ }^{\circledR}$ paste thickened with zinc oxide, Sealapex ${ }^{\circledR}$ sealer, zinc oxide and eugenol cement and EndoREZ ${ }^{\mathrm{TM}}$ sealer. The Calen ${ }^{\circledR}$ paste thickened with zinc oxide permitted the occurrence of an adequate tissue response, while Sealapex ${ }^{\circledR}$ sealer and the zinc oxide and eugenol cement produced a fair tissue response. EndoREZ ${ }^{\mathrm{TM}}$ sealer did not induce tissue repair.

Key-words: Calen ${ }^{\circledR}$, Sealapex ${ }^{\circledR}$, EndoREZ ${ }^{T M}$, Óxido de zinco e eugenol, Antibacterial activity, Biocompatibility. 


\section{SUMÁRIO}

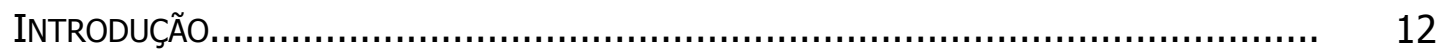

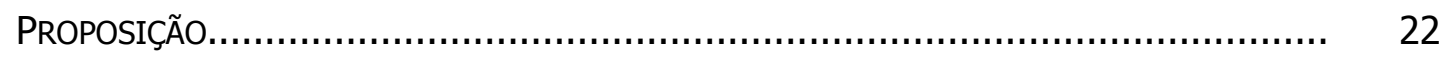

MATERIAL E MÉTODOS............................................................ 24

1) Atividade Antimicrobiana in vitro - Teste de Difusão em Ágar........................... 25

2) Compatibilidade Tecidual in vivo - Estudo em Camundongos Isogênicos............. 28

RESULTADOS........................................................................ 34

1) Atividade Antimicrobiana in vitro - Teste de Difusão em Agar.......................... 35

2) Compatibilidade Tecidual in vivo - Estudo em Camundongos Isogênicos.............. 41

DISCUSSÃO......................................................................... 57

1) Atividade Antimicrobiana in vitro - Teste de Difusão em Ágar.......................... 58

2) Compatibilidade Tecidual in vivo - Estudo em Camundongos Isogênicos............. 70

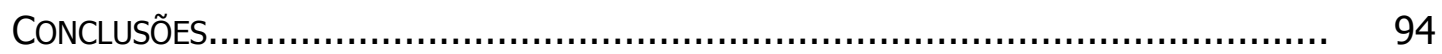

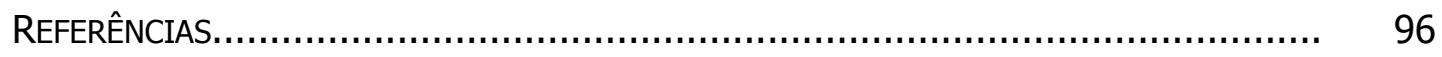

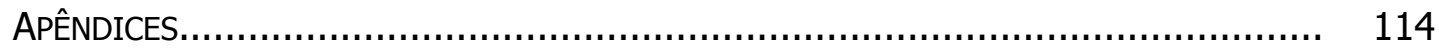

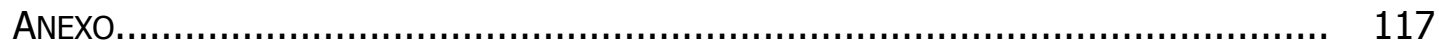


INTRODUÇÃO 


\section{INTRODUÇÃO}

Os dentes decíduos participam de funções essenciais para 0 desenvolvimento da criança tais como mastigação, fonação e estética. Além disso, preservam o espaço no arco dental para a erupção dos dentes sucessores permanentes e estimulam o crescimento em altura dos maxilares, sendo fundamental sua manutenção na cavidade bucal em condições anatômicas e funcionais, até a época normal de sua esfoliação (Barr et al., 1991; Fuks, 2000; Assed, 2005; Primosch et al., 2005; Kielbassa et al., 2007; Robke, 2008).

Apesar da crescente adoção de medidas preventivas, voltadas para a promoção da saúde bucal, os dentes decíduos ainda são, freqüentemente, afetados pela cárie dental que, com sua progressão, pode ocasionar alterações pulpares e periapicais (Rocha et al., 2008; Sari e Okte, 2008), tornando necessária a execução do tratamento endodôntico. O comprometimento do órgão pulpar em decorrência de traumatismos dentais também é altamente prevalente em crianças (Goerig e Camp, 1983; Oliveira et al., 2007).

Embora o tratamento endodôntico dos dentes decíduos venha sendo preconizado desde 1932 (Gerlach, 1932), a forma de se efetuar esse tratamento permanece controversa, havendo uma ampla variedade de materiais e técnicas empregadas, tanto nos dentes decíduos com vitalidade, quanto com necrose pulpar (Hobson, 1970; Allen, 1979; Guedes-Pinto et al., 1981; Tagger e Sarnat, 1984; GarciaGodoy, 1987; Barr et al., 1991; Yacobi et al., 1991; Kubota et al., 1992; Sadrian e Coll, 1993; Puppin-Rontani et al., 1994; Ranly, 1994; Primosch et al., 1997; Ranly e GarciaGodoy, 2000; Mani et al., 2000; Barroso, 2003; Pazelli et al., 2003; Mortazavi e Mesbahi, 2004; Silva et al., 2004; Assed, 2005; Faria et al., 2005; Ozalp et al., 2005; Primosch et al., 2005; Bawazir e Salama, 2006; Silva et al., 2006; Ruviére et al., 2007).

Historicamente, diversas técnicas para o tratamento endodôntico de dentes decíduos foram desenvolvidas de maneira empírica (Hobson, 1970). As técnicas de pulpectomia consistiam em modificações da técnica de pulpotomia, adaptadas para o tratamento de dentes decíduos com necrose pulpar, inclusive nos casos de abscessos (Rifkin, 1980). Realizava-se somente a manipulação da câmara pulpar, sem a instrumentação dos canais radiculares, baseando-se quase que exclusivamente na ação bactericida e bacteriostática dos medicamentos (Foster, 1936; Droter, 1967; Benfatti e Andrioni, 1969; Hobson, 1970). O tricresol formalina, o paramonoclorofenol canforado, o eugenol e o timol, usados de forma isolada ou associados a antibióticos, 
eram os medicamentos mais utilizados com essa finalidade (Guedes-Pinto, 2003). No entanto, esses medicamentos não promoviam a reparação dos tecidos apicais e periapicais (Waterhouse, 1995; Lewis, 1998).

Além disso, em virtude dos dentes decíduos apresentarem um sistema de canais radiculares bastante complexo, nos quais além do canal principal são encontrados canais secundários e acessórios, ramificações colaterais e bifurcações ou ramificações apicais em grande número, associada à proximidade com o germe do dente permanente sucessor e à presença da reabsorção fisiológica de suas raízes, alguns autores contra-indicavam o tratamento endodôntico radical desses dentes (Hibbard e Ireland, 1957; Toledo, 1961; Benfatti, 1966; Scheffer, 1973; Tagger e Sarnat, 1984).

Porém, os dentes permanentes também apresentam essa complexidade morfológica do sistema de canais radiculares e, nem por isso, o tratamento endodôntico radical deixa de ser efetuado com sucesso, nesses dentes (Leonardo, 2005). Com relação à proximidade das raízes dos dentes decíduos com o germe do dente permanente sucessor e à reabsorção fisiológica das mesmas, deve-se partir da premissa de que a manipulação dos canais radiculares dos dentes decíduos precisa ser efetuada dentro de limites de segurança, sendo isso possível com um recuo do instrumento endodôntico em 1 a 1,5mm, a partir do limite apical radiográfico (Rifkin, 1980; Bengtson e Guedes-Pinto, 1983; Rosendahl e Weinert-Grodd, 1995; Pazelli et al., 2003; Assed, 2005; Faria et al., 2005; Ruviére et al., 2007) ou com o uso de localizadores eletrônicos foraminais (Leonardo et al., 2008; Tosun et al., 2008).

$\mathrm{Na}$ atualidade, preconiza-se que, em casos de alterações pulpares inflamatórias irreversíveis ou de polpas necrosadas, associadas ou não à presença de lesões periapicais visíveis radiograficamente, o preparo biomecânico dos canais radiculares de dentes decíduos deve ser realizado (Kramer et al., 2000; Pazelli et al., 2003; American Academy of Pediatric Dentistry, 2005-2006; Assed, 2005; Faria et al., 2005; Bawazir e Salama, 2006; Johnson et al., 2006; Rood et al., 2006; Srinivasan et al., 2006; Ruviére et al., 2007) com limas manuais ou acionadas a motor (Barr et al., 1999; Silva et al., 2004; Leonardo et al., 2007-b), efetuando-se o curativo de demora entre sessões (Pazelli et al., 2003; Assed, 2005; Faria et al., 2005; Ruviére et al., 2007) e a obturação dos canais radiculares com materiais fagocitáveis, às vezes também referidos como "reabsorvíveis" (Kramer et al., 2000; Barroso, 2003; GuedesPinto, 2003; Pazelli et al., 2003; Assed, 2005; Ozalp et al., 2005; Primosch et al., 2005; Bawazir e Salama, 2006; Faria et al., 2005; Ruviére et al., 2007). 
De acordo com Rifkin (1980), Machida (1983), Woods (1984), GarciaGodoy (1987), Kubota et al. (1992) e Assed (2005), as características ideais de um material obturador de canais radiculares de dentes decíduos incluem: ser fagocitado simultaneamente à reabsorção das raízes dos dentes decíduos, inclusive quando acidentalmente extravasado; apresentar compatibilidade com os tecidos apicais e periapicais, estimulando ou permitindo o reparo por meio da deposição de tecido mineralizado de natureza cementária ou de tecido conjuntivo fibroso; ser facilmente inserido no interior dos canais e removido se necessário; possuir atividade antimicrobiana; ser radiopaco; aderir às paredes do canal radicular sem sofrer contração; não ser solúvel em água; não promover a descoloração do dente e não tomar presa em forma de uma massa compacta que interfira com a erupção do dente permanente sucessor.

Embora diferentes materiais sejam preconizados para a obturação de canais radiculares de dentes decíduos, nenhum deles preenche adequadamente todos os requisitos exigidos para ser considerado um material obturador ideal (Fuks, 2000; Assed, 2005; Cunha et al., 2005).

Os materiais à base de óxido de zinco e eugenol, embora sejam empregados para a obturação de canais radiculares de dentes decíduos (Sweet, 1930; Foster, 1936; Hobson, 1970; Gould, 1972; Spedding, 1973; O'Riordan e Coll, 1979; Camp, 1984; Coll et al., 1988; Hasselgren et al., 1988; Payne et al., 1993; Sandrian e Coll, 1993; Coll e Sandrian, 1996; Primosch et al., 1997; Mani et al., 2000; Ozalp et al., 2005; Primosch et al., 2005), podem desencadear reação inflamatória crônica nos tecidos periapicais (Erausquin e Muruzábal, 1967; Holland et al., 1977; Hendry et al., 1982; Woods et al., 1984; Barroso, 2003; Ho et al., 2006). Seu potencial de irritação é atribuído principalmente ao eugenol (Molnar, 1967; Becker et al., 1983; Barkin et al., 1984; Hume, 1984; Hume, 1986; Yesikov et al., 1988; Markowitz et al.,1992; Economides et al., 1995; Segura et al., 1998; Sarrami et al., 2002), o qual pode permanecer em sua forma livre por até 10 anos (Molnar, 1967; Yesilsov et al., 1988).

O eugenol altera a capacidade de aderência ao substrato dos macrófagos e, conseqüentemente, o processo de fagocitose (Segura et al., 1998); altera a função antimicrobiana dos neutrófilos influenciando a reação inflamatória nos tecidos periapicais (Chen et al., 2008); em altas concentrações atua como inibidor da respiração celular (Hume, 1984; Markowitz et al., 1992) e é bactericida (Markowitz et al., 1992); e em baixas concentrações inibe a quimiotaxia de células leucocitárias, a síntese de prostaglandinas e a atividade nervosa (Markowitz et al., 1992). Erausquin e 
Muruzábal (1967) observaram uma elevada toxidade do cimento de óxido de zinco e eugenol nos tecidos periapicais em dentes de ratos, com necrose óssea e cementária. Outro inconveniente é o fato deste composto apresentar baixa capacidade de ser fagocitado e eliminado, permanecendo partículas de óxido de zinco e eugenol nos tecidos periapicais, mesmo com a reabsorção radicular fisiológica (Erausquin e Muruzábal, 1967; Allen, 1979; Rifkin, 1980; Hendry et al., 1982; Spedding, 1985; Kubota et al., 1992; Fuks, 2000; Mani et al., 2000; Casas et al., 2004; Primosh et al., 2005). De acordo com Coll e Sandrian (1996) e Mortazavi e Mesbahi (2004) esse material obturador altera o trajeto de erupção do dente sucessor permanente em $20 \%$ dos casos e apresenta elevada infiltração marginal apical (Bawazir e Salama, 2007).

Outra classe de materiais utilizados para obturação de canais radiculares de dentes decíduos são os que contêm iodofórmio (Juge, 1959; Rifkin, 1980; GuedesPinto et al., 1981; Rifkin, 1982; Michel, 1984; Tagger e Sarnat, 1984; Garcia-Godoy, 1987; Mass e Zilberman, 1989; Chedid et al., 1992; Holan e Fuks, 1993; PuppinRontani et al., 1994; Thomas et al., 1994, Bonow et al., 1996; Reddy et al., 1996; Gomes, 1997; Santos, 1998; Ranly e Garcia-Godoy, 2000; Santos, 2002; Guedes-Pinto, 2003; Mortazavi e Mesbahi, 2004; Cerqueira et al., 2008). Estes materiais têm sido indicados por apresentarem ação anti-séptica de longa duração (Juge, 1959), atividade antimicrobiana (Thomas et al., 1994; Cerqueira et al., 2008), serem bem tolerados pelos tecidos (Rifkin, 1980; Garcia-Godoy, 1987; Guedes-Pinto, 2003; Cerqueira et al., 2008) e serem fagocitáveis (Rifkin, 1980; Garcia-Godoy, 1987; Mass e Zilberman, 1989; Thomas et al., 1994; Guedes-Pinto, 2003).

Entretanto, Faraco Júnior e Percinoto (1998), após a utilização em dentes de cães de uma pasta composta por iodofórmio, paramonoclorofenol canforado e Rifocort $^{\circledR}$ (Medley S.A. Ind. Farm., Campinas, SP-Brasil) observaram inflamação crônica na região periapical e áreas de reabsorção radicular apical. As pastas iodoformadas apresentam também rápida reabsorção pelo organismo, deixando espaços vazios no interior do canal radicular (Kubota et al., 1992). Foi ainda atribuído ao seu uso casos de intoxicação, manifestações alérgicas e, quando em grande quantidade, envenenamento sistêmico (Bollmann, 1957), além da possibilidade de encefalopatia quando o iodofórmio é associado ao bismuto (Roy et al., 1994). Observase, também, escurecimento dental após o emprego de materiais obturadores à base de iodofórmio (Garcia-Godoy, 1987).

Um outro grupo de materiais utilizados para a obturação de canais radiculares de dentes decíduos corresponde ao grupo dos materiais à base de 
hidróxido de cálcio (Fuchino et al., 1978; Fuchino, 1980; Hendry et al., 1982; Machida, 1983; Kawakami et al., 1987; Rosendahl e Weinert-Grodd, 1995; Faraco-Júnior e Percinoto, 1998; Mani et al., 2000; Nery, 2000; Chawla et al., 2001; Nurko et al., 2000; Murata, 2002; Barroso, 2003; Pazelli et al., 2003; Mortazavi e Mesbahi, 2004; Assed, 2005; Faria et al., 2005; Ozalp et al., 2005; Leonardo et al., 2007-b; Sari e Okte; 2008). Porém, apesar das excelentes propriedades biológicas do hidróxido de cálcio (Silva, 1988; Nelson-Filho et al., 1999; Lu et al., 2006; Murray et al., 2007; Huang et al., 2007; Chawla et al., 2008), este não apresenta propriedades físicas adequadas ao uso clínico, pois é permeável aos fluidos teciduais e solúvel no interior do canal radicular. Além disso, apresenta pouco escoamento, viscosidade e aderência, sendo também radiolúcido. Assim, para permitir sua utilização como material obturador de canais radiculares de dentes decíduos, o hidróxido de cálcio tem sido associado a outras substâncias que possam melhorar seu estado físico e radiopacidade (Assed, 2005).

A pasta Calen $^{\circledR}$ é um produto à base de hidróxido de cálcio associado a um veículo hidrossolúvel, viscoso, o polietilenoglicol 400, que mantém o hidróxido de cálcio por mais tempo na área desejada, prolongando sua ação, diminuindo sua solubilização e aumentando sua penetrabilidade na dentina radicular (Leonardo et al., 1993; Leonardo et al., 2005). Essa pasta apresenta pH em torno de 12,4, e sofre dissociação em íons cálcio e hidroxila (Silva, 1988; Nelson-Filho, 1996).

Materiais que contêm hidróxido de cálcio em sua composição, apresentarão propriedades biológicas e antimicrobianas, se ocorrer a liberação de íons cálcio e hidroxila (Estrela et al., 1995). A liberação de íons hidroxila promove o aumento do pH na região periapical e apresenta potencial bactericida (Hosoya et al., 2001). A difusão de íons hidroxila, através da dentina radicular, altera o pH da superfície radicular externa e interfere com a atividade osteoclástica (Tronstad et al., 1981). O aumento do pH interfere com funções celulares dos fibroblastos, estimulando o processo de reparo na superfície radicular (Lengheden e Jansson, 1995) e participa da formação de tecido mineralizado com ativação da fosfatase alcalina e da síntese de colágeno (Schroder, 1985). A liberação de íons cálcio é importante pois, quando em abundância no tecido, ocorre sua participação no processo de ativação da adenosina trifosfatase cálcio dependente (Seux et al., 1991). Os íons cálcio reagem com o gás carbônico do tecido e formam cristais de carbonato de cálcio, que servem de núcleos de calcificação e favorecem mineralização (Seux et al., 1991; Estrela et al., 1995). 
Ainda, ao reagir com o gás carbônico do tecido, os íons cálcio reduzem a fonte de respiração das bactérias anaeróbias (Estrela et al., 1995; Kontakiotis et al., 1995).

$\mathrm{Na}$ Odontologia, a pasta Calen $^{\circledR}$ tem sido amplamente utilizada em diversas situações clínicas pelas suas propriedades que incluem: compatibilidade com a atividade biológica dos tecidos circundantes (Silva, 1988; Silva e Leonardo, 1995; Leonardo et al., 1996; Nelson-Filho, 1996; Bittencourt e Mallman, 1997; Motta et al., 1997; Holland et al., 1999; Nelson-Filho et al., 1999; Santos et al., 2000; Delgado, 2002; Leonardo et al., 2003; Barroso, 2003; Assed, 2005; Leonardo, 2005; Herrera et al., 2006; Leonardo et al., 2006; Silva, 2007); atividade antimicrobiana (Assed, 1994; Leonardo et al., 1995; Leonardo et al., 2000; Pazelli et al., 2003; Faria et al., 2005; Leonardo, 2005; Silva, 2007); ação anti-exsudativa (Leonardo et al., 2005); dissolução de restos necróticos (Leonardo et al., 2005); ação indutora da deposição de tecido mineralizado, ativação da fosfatase alcalina e síntese de colágeno (Leonardo et al., 1997; Leonardo, 2005; Herrera et al., 2006; Leonardo et al., 2006) e hidrólise da endotoxina bacteriana ou LPS (Nelson-Filho et al., 2002; Silva et al., 2002; Tanomaru et al., 2003; Oliveira et al., 2005).

Para permitir sua utilização como material obturador de canais radiculares de dentes decíduos, a pasta Calen ${ }^{\circledR}$ deve ser espessada com óxido de zinco (Silva e Leonardo, 1995; Assed, 2005; Leonardo et al., 2007-b), reduzindo sua fagocitose, a qual clinicamente deve ocorrer na mesma velocidade da reabsorção das raízes dos dentes decíduos. A pasta Calen $^{\circledR}$ espessada já foi utilizada por vários pesquisadores (Barroso, 2003; Bezerril, 2003; Pazelli et al., 2003; Rabelo, 2003; Faria et al., 2005) e mostrou compatibilidade com a atividade biológica dos tecidos, in vivo (Barroso, 2003) e selamento satisfatório do canal radicular, com pequena infiltração marginal, in vitro (Bezerril, 2003).

O Sealapex ${ }^{\circledR}$, um cimento à base de hidróxido de cálcio, amplamente utilizado como material obturador de canais radiculares de dentes permanentes, apresenta reconhecida compatibilidade com a atividade biológica dos tecidos (Molloy et al., 1992; Mittal et al., 1995, Leonardo et al., 1997; Silva et al., 1997-a; Berbert et al., 2002; Leonardo et al., 2003; Leonardo, 2005; Masuda et al., 2005), capacidade de indução de selamento apical (Leonardo et al., 2003; Cobankara et al., 2006) e atividade antimicrobiana (Leonardo et al., 2000; Sipert et al., 2005; Tanomaru-Filho et al., 2007-b). Há relatos na literatura específica do uso do cimento Sealapex ${ }^{\circledR}$ como material obturador de canais radiculares de dentes decíduos, apresentando sucesso clínico e radiográfico (Alves e Vieira, 2005; Ozalp et al., 2005; Sari e Okte, 2008) e 
pequena infiltração marginal apical (Kielbassa et al., 2007). De acordo com Olzap et al. (2005), quando utiliza-se o cimento Sealapex ${ }^{\circledR}$ como material obturador de canais radiculares de dentes decíduos, a sua fagocitose ocorre antes da reabsorção radicular fisiológica em $10 \%$ dos casos.

Recentemente foi introduzido no mercado um cimento endodôntico à base de metacrilato denominado EndoREZ ${ }^{\mathrm{TM}}$. Este cimento contém em sua formulação óxido de zinco, sulfato de bário, resinas e pigmentos em uma matriz resinosa de dimetacrilato de uretano. Além disso, apresenta propriedade hidrofílica e presa química (Sousa et al., 2006), é radiopaco (Tanomaru-Filho et al., 2007-a) e permite adequado selamento marginal, por apresentar baixos níveis de infiltração (Adanir et al., 2006; Pereira et al. 2007). Zmener e Pameijer (2004) observaram resultados clínicos e radiográficos satisfatórios em 91,3\% dos 180 pacientes avaliados aos 14 e 24 meses, após obturação do canal radicular de dentes permanentes com cimento EndoREZ ${ }^{\circledR}$. No entanto, a citotoxicidade (Bouillaguet et al., 2004; Eldeniz et al., 2007; Lodiene et al., 2008), a compatibilidade com a atividade biológica dos tecidos (Zmener, 2004; Zmener et al., 2005; Sousa et al., 2006; Zafalon et al., 2007) e a atividade antimicrobiana (Sipert et al., 2005; Eldeniz et al., 2006) desse cimento são propriedades pouco investigadas e com resultados contraditórios, até o momento.

O uso do cimento EndoREZ ${ }^{\text {TM }}$ como material obturador de canais radiculares de dentes decíduos não foi ainda relatado e avaliado na literatura específica. No entanto, em 1984, Woods et al. avaliaram microscopicamente em dentes decíduos de cães um cimento obturador à base de metacrilato, verificando que este material se mostrou compatível com a atividade biológica dos tecidos, sendo fagocitado por macrófagos na mesma velocidade da reabsorção das raízes, indicando seu uso como material obturador de canais radiculares de dentes decíduos.

Pelo exposto, ressalta-se que não há um material obturador de canais radiculares de dentes decíduos com todas as características físicas e biológicas desejáveis. Deve-se enfatizar que os materiais inseridos em canais radiculares de dentes decíduos ficarão em contato com os tecidos periapicais, principalmente durante a rizólise, e em íntima proximidade com o germe do dente sucessor permanente por longos períodos de tempo (Coll e Sandrian, 1996; Mortazavi e Mesbahi, 2004; Assed, 2005; Johnson et al., 2006). Assim, dentre as diversas propriedades desejáveis destaca-se a compatibilidade com a atividade biológica dos tecidos, a qual representa um dos requisitos mais importantes, especialmente por tratar de dentes que se encontram em organismos em desenvolvimento (Woods et al., 1984; Santos, 1998; 
Barroso, 2003; Ozbas et al., 2003; Bouillaguet et al., 2004; Zmener, 2004; Assed, 2005; Huang et al., 2005; Huang et al., 2007; Sari e Okte, 2008).

Outra característica de fundamental importância para um material obturador de canais radiculares de dentes decíduos, particularmente em casos de necrose pulpar, é a presença de atividade antimicrobiana (Cox et al., 1978; Rifkin, 1980; Tchaou et al., 1996; Assed, 2005; Sipert et al., 2005; Amorim et al., 2006; Eldeniz et al., 2006; Kielbassa et al., 2007; Reddy e Ramakrishna, 2007; Sari e Okte, 2008). Nesses dentes, embora diversos fatores influenciem o sucesso do tratamento endodôntico, a redução ou eliminação da microbiota do sistema de canais radiculares é de fundamental importância (Tronstad, 1992; Sipert et al., 2005; Reddy e Ramakrishna, 2007). De acordo com Tchaou et al. (1995), a redução ou eliminação das bactérias nos canais radiculares de dentes decíduos infectados ocorre por meio da instrumentação, da irrigação e da obturação com materiais antimicrobianos.

Além disso, atualmente, enfatiza-se a importância do uso de um curativo de demora entre sessões, nos casos de necrose pulpar e lesão periapical, para eliminar ou reduzir a microbiota (Pazelli et al., 2003; Assed, 2005; Faria et al., 2005; Ruviére et al., 2007). Nesses casos, as bactérias não estão localizadas somente na luz do canal principal, mas disseminadas pelo sistema de canais radiculares (Shovelton, 1964; Hobson, 1970; Leonardo et al., 1994; Percinoto, 1997; Ribeiro, 1997; Godoy, 1999; Rocha et al., 2008) e nas áreas de rizólise (Godoy, 1999; Rocha et al., 2008). Godoy (1999) verificou que em dentes decíduos com necrose pulpar, bactérias planctônicas, agregados bacterianos e biofilmes estavam presentes na câmara pulpar, nas paredes do canal radicular, nos túbulos dentinários e na superfície radicular externa da região apical. Em 2008, Rocha et al. observaram, em microscopia eletrônica de varredura, a presença de áreas de reabsorção contendo microrganismos (cocos, bacilos, filamentos e espiroquetas) organizados em forma de biofilme na superfície radicular externa de dentes decíduos de humanos, com necrose pulpar e lesão periapical visível radiograficamente.

Com relação à prevalência de microrganismos em canais radiculares de dentes decíduos de humanos com necrose pulpar e lesão periapical, Onçag et al. (2003) relataram $81,5 \%$ de microrganismos anaeróbios e anaeróbios facultativos. Pazelli et al. (2003), por meio de cultura microbiana, observaram que os microrganismos anaeróbios foram encontrados e quantificados em $96,7 \%$ dos casos. Em 2006, Silva et al., também por meio de cultura microbiana, observaram que os microrganismos anaeróbios foram quantificados em $100 \%$ dos casos, os bacilos pigmentados de negro em $30 \%$, os 
aeróbios em $60 \%$, os estreptococos em $85 \%$, os estreptococos do grupo mutans em $30 \%$ e os bacilos gram-negativos aeróbios em 15\% dos casos. Os autores concluíram que nesses canais radiculares a infecção é polimicrobiana com predominância de microrganismos anaeróbios. Esses dados foram confirmados por Ruviére et al. (2007) que observaram infecção polimicrobiana, com predomínio de microrganismos anaeróbios em $94,1 \%$ dos canais radiculares de dentes decíduos humanos com necrose pulpar e lesão periapical, por meio do uso de técnica de biologia molecular (Checkerboard DNADNA Hybridization).

Em 2005, Faria et al. avaliaram, por meio de cultura microbiana, a ação antibacteriana do preparo biomecânico, utilizando como solução irrigadora o hipoclorito de sódio a $2,5 \%$ e como curativo de demora a pasta Calen ${ }^{\circledR}$, em canais radiculares de dentes decíduos de humanos com necrose pulpar e lesão periapical. Verificaram que o preparo biomecânico foi eficaz na eliminação de microrganismos dos canais radiculares em $20 \%$ dos casos e o curativo de demora em $62,5 \%$, enquanto que a ação cumulativa do preparo biomecânico e do curativo de demora foi eficaz na eliminação de microrganismos dos canais radiculares em $70 \%$ dos casos, o que justifica o uso do curativo de demora entre sessões nesses dentes.

Assim, com a finalidade de elevar a porcentagem de sucesso póstratamento endodôntico de dentes decíduos, é de fundamental importância a escolha de um material obturador que apresente compatibilidade tecidual e possua atividade antimicrobiana. 
Proposição 


\section{ProposiçÃo}

O objetivo deste estudo foi avaliar os seguintes materiais obturadores de canais radiculares de dentes decíduos: cimento à base de óxido de zinco e eugenol, pasta à base de hidróxido de cálcio (Calen ${ }^{\circledR}$ ) espessada com óxido de zinco; cimento à base de hidróxido de cálcio (Sealapex ${ }^{\circledR}$ ) e cimento à base de metacrilato (EndoREZ ${ }^{\mathrm{TM}}$ ), com relação à:

1- Atividade antibacteriana in vitro, por meio do teste de difusão em ágar, sobre diferentes microrganismos indicadores (Kocuria rizophila, Enterococcus faecalis, Streptococcus mutans, Escherichia coli e Staphylococcus aureus); e

2- Compatibilidade tecidual, em microscopia óptica, após implantação de tubos de polietileno contendo os respectivos materiais no tecido conjuntivo subcutâneo de camundongos isogênicos (estudo in vivo). 
Material e Métodos 


\section{Material e Métodos}

\section{1) Atividade Antibacteriana in vitro- Teste de Difusão em Ágar}

A atividade antibacteriana dos seguintes materiais foi avaliada in vitro:

- cimento de óxido de zinco e eugenol (S.S.White Artigos Dentários Ltda, Rio de Janeiro, RJ-Brasil);

- pasta Calen ${ }^{\circledR}$ (S.S.White Artigos Dentários Ltda, Rio de Janeiro, RJ-Brasil) espessada com óxido de zinco (S.S.White Artigos Dentários Ltda, Rio de Janeiro, RJBrasil);

- cimento Sealapex ${ }^{\circledR}$ (Sybron Endo, Glendora, CA, EUA); e

- cimento EndoREZ ${ }^{\mathrm{TM}}$ (Ultradent Products Inc., South Jordan, UT, USA).

Foram utilizados como controles a pasta Calen $^{\circledR}$, o Digluconato de Clorexidina a 1\% (Farmácia Doce Erva, Ribeirão Preto, São Paulo, Brasil) e a água destilada.

A Tabela 1 apresenta a procedência e o tipo morfológico das cepas utilizadas como indicadoras da atividade antibacteriana, enquanto a Tabela 2 apresenta a composição e a proporção utilizada para cada material.

Tabela 1 - Procedência e tipo morfológico das cepas utilizadas como indicadoras da atividade antibacteriana

\begin{tabular}{lll}
\hline Microrganismos & Procedência & Tipo morfológico \\
\hline Kocuria rhizophila & ATCC 9341 & Coco Gram-positivo \\
Enterococcus faecalis & ATCC 10541 & Coco Gram-positivo \\
Streptococcus mutans & ATCC 25175 & Coco Gram-positivo \\
Escherichia coli & ATCC 10538 & Bacilo Gram-negativo \\
Staphylococcus aureus & ATCC 6538 & Coco Gram-positivo \\
\hline
\end{tabular}

ATCC: American Type Culture Collection 
Tabela 2 - Composição química dos materiais avaliados e proporção utilizada

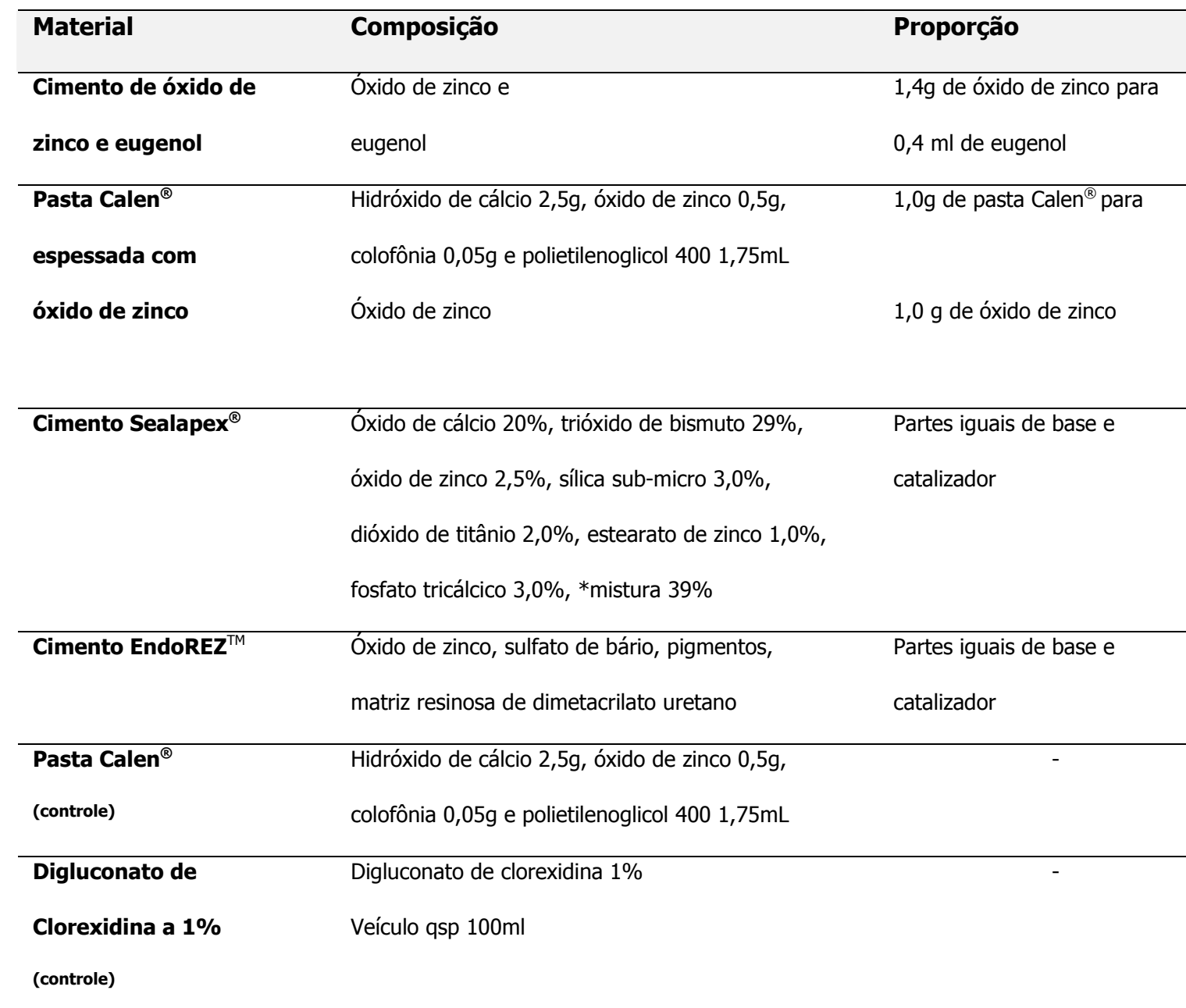

Água destilada

(controle)

*Sulfonamida de tolueno etil, resina poli (salicilato de metil metileno), salicilato de isobutil e pigmento

Os inóculos foram obtidos por meio da suspensão em salina das cepas cultivadas em MHb (Mueller Hinton Broth, Difco ${ }^{\mathrm{TM}}$, Detroit, MI, USA) na densidade de 2-3 da escala de McFarland para Kocuria rhizophila (anteriormente denominado Micrococcus luteus) e de 0,5 para Escherichia coli e Staphylococcus aureus, e por meio da diluição em salina das cepas cultivadas em TSb (Tryptic Soy Broth, Difco ${ }^{\mathrm{TM}}$, Detroit, MI, USA) na densidade de 1 da escala de McFarland para Enterococcus faecalis e de 12 para Streptococcus mutans.

Para o teste de difusão em ágar foi empregado o método do poço, utilizando o meio de cultura MH (Mueller-Hinton-Medium, Difco ${ }^{\mathrm{TM}}$, Detroit, MI, USA) para Kocuria rhizophila, Escherichia coli e Staphylococcus aureus e o meio TSA 
(Tryptic-Soy-Agar- Difco ${ }^{\mathrm{TM}}$, Detroit, MI, USA) para Enterococcus faecalis e Streptococcus mutans.

No fluxo laminar, a camada base (base layer) foi obtida vertendo-se $12 \mathrm{ml}$ de meio de cultura TSA ou $\mathrm{MH}$, a aproximadamente $50^{\circ} \mathrm{C}$, em placas de Petri de 20X100mm, esterilizadas. Após solidificação da camada base, adicionou-se a camada seed (seed layer), composta de $8 \mathrm{ml}$ de meio de cultura TSA ou $\mathrm{MH}$, a $50^{\circ} \mathrm{C}$, com $10^{6}$ unidades formadoras de colônia (ufc) por $\mathrm{ml}$ do inóculo original (escala 2-3 de McFarland para Kocuria rhizophila; 0,5 (metade da escala 1) para Escherichia coli e Staphylococcus aureus, 1 para Enterococcus faecalis e 1-2 para Streptococcus mutans).

Após solidificação, foram realizadas 7 perfurações (poços) eqüidistantes na superfície dos meios de cultura, com $5 \mathrm{~mm}$ de diâmetro. Cada poço foi preenchido com um dos materiais a serem testados. Os materiais comercializados foram manipulados de acordo com as instruções dos fabricantes e a pasta Calen ${ }^{\circledR}$ espessada com óxido de zinco foi obtida espatulando-se em placa de vidro esterilizada $1 \mathrm{~g}$ da pasta Calen ${ }^{\circledR}$ com $1 \mathrm{~g}$ de óxido de zinco, os materiais foram utilizados imediatamente após sua manipulação.

O teste foi efetuado em seis repetições, ou seja, foram utilizadas seis placas para cada microrganismo avaliado. As placas foram mantidas à temperatura ambiente por duas horas, para que ocorresse a pré-difusão do material. A seguir, as placas de $\mathrm{MH}$ foram incubadas em aerobiose e as placas de TSA em microaerofilia (sistema de chama de vela), a $37^{\circ} \mathrm{C}$ por 24 horas. Após o período de incubação, a zona de inibição foi mensurada em milímetros, com uma régua, sob luz refletida.

\section{Análise Estatística}

Os dados foram analisados utilizando-se o programa estatístico Graph Pad Prism $4^{\mathcal{O}}$ (Graph Pad Software In., San Diego, Califórnia, EUA). Os resultados da atividade antibacteriana dos materiais foram comparados empregando a análise de variância (ANOVA) e pós-teste de Tukey. O nível de significância adotado foi de 5\%. 


\section{2) Compatibilidade Tecidual in vivo - Estudo em Camundongos Isogênicos}

Preliminarmente o projeto de pesquisa foi aprovado pela Comissão de Ética no Uso de Animais - Campus de Ribeirão Preto - Universidade de São Paulo, sob protocolo número 07.1.124.53.0. Os critérios utilizados para a execução do experimento e para avaliação da reação tecidual basearam-se naqueles preconizados pela ISO 10993-6 (1994).

Foram utilizados 132 camundongos isogênicos da linhagem BALB/C, machos, com 6 a 8 semanas de idade, pesando de 15 a 20 gramas, provenientes do Biotério Central da Faculdade de Medicina de Ribeirão Preto - USP, os quais foram divididos em 14 grupos. Cada animal recebeu um implante de tubo de polietileno na região dorsal, contendo um dos materiais a serem testados (grupos experimentais) ou tubo vazio (grupos controles). A divisão dos grupos, materiais empregados, número de animais e períodos experimentais encontram-se na Tabela 3.

Tabela 3 - Divisão dos grupos, materiais empregados, número de animais e períodos experimentais, no estudo em camundongos isogênicos

\begin{tabular}{|c|c|c|c|}
\hline GRUPOS & MATERIAIS & NÚMERO DE ANIMAIS & Períodos \\
\hline $\mathbf{I}$ & $\begin{array}{l}\text { Pasta Calen }{ }^{\circledR} \text { espessada com óxido de } \\
\text { zinco }\end{array}$ & 10 & 7 dias \\
\hline II & Cimento EndoREZ ${ }^{\mathrm{TM}}$ & 10 & 7 dias \\
\hline III & Cimento Sealapex ${ }^{\circledR}$ & 10 & 7 dias \\
\hline IV & Cimento de óxido de zinco e eugenol & 10 & 7 dias \\
\hline $\mathbf{v}$ & $\begin{array}{l}\text { Pasta Calen }{ }^{\circledR} \text { espessada com óxido de } \\
\text { zinco }\end{array}$ & 10 & 21 dias \\
\hline VI & Cimento EndoREZ ${ }^{\mathrm{TM}}$ & 10 & 21 dias \\
\hline VII & Cimento Sealapex ${ }^{\circledR}$ & 10 & 21 dias \\
\hline VIII & Cimento de óxido de zinco e eugenol & 10 & 21 dias \\
\hline IX & $\begin{array}{l}\text { Pasta Calen }{ }^{\circledR} \text { espessada com óxido de } \\
\text { zinco }\end{array}$ & 10 & 63 dias \\
\hline $\mathbf{x}$ & Cimento EndoREZ ${ }^{\mathrm{TM}}$ & 10 & 63 dias \\
\hline $\mathbf{X I}$ & Cimento Sealapex ${ }^{\circledR}$ & 10 & 63 dias \\
\hline XII & Cimento de óxido de zinco e eugenol & 10 & 63 dias \\
\hline XIII & Tubo vazio & 6 & 7 dias \\
\hline XIV & Tubo vazio & 6 & 21 dias \\
\hline
\end{tabular}




\section{Preparo dos Tubos de Polietileno}

Foram utilizados tubos de polietileno com lume de $1 \mathrm{~mm}$ de diâmetro, os quais tiveram uma extremidade fechada com o auxílio de uma pinça clínica aquecida e cortados com $1 \mathrm{~cm}$ de comprimento. Os tubos de polietileno foram esterilizados por óxido de etileno e preenchidos com os materiais a serem testados, de maneira que se assegurasse que esses não fossem arranhados, danificados ou contaminados em qualquer fase antes ou durante a inserção. Os materiais comercializados foram manipulados conforme as instruções dos fabricantes e a pasta Calen ${ }^{\circledR}$ espessada com óxido de zinco foi obtida espatulando-se $1 \mathrm{~g}$ da pasta Calen ${ }^{\circledR}$ com $1 \mathrm{~g}$ de óxido de zinco, em placa de vidro esterilizada. A manipulação dos materiais foi realizada sob condições de assepsia (fluxo laminar) e imediatamente antes do preenchimento dos tubos e de sua implantação.

\section{Procedimento Operatório}

Para o ato cirúrgico, os animais foram anestesiados com hidrato de cloral a $10 \%(1 \mathrm{ml} / 100 \mathrm{~g}$ de peso corporal do animal), injetado intraperitonealmente. Em seguida, foram realizadas a tricotomia da pele do dorso do animal e a anti-sepsia da região com digluconato de clorexidina a $1 \%$.

O procedimento cirúrgico consistiu em uma incisão de $1 \mathrm{~cm}$, efetuada com tesoura cirúrgica, na região dorsal do animal, seguida de divulsão com tesoura romba. Após posicionar o tubo no interior do tecido conjuntivo, com auxílio de pinça clínica, a pele foi suturada com fio de seda (Vicryl 4-0 ${ }^{\circledR}$ - Ethicon - Johnson \& Johnson). A cirurgia foi realizada sob condições assépticas e de forma a minimizar o trauma à área do implante.

Os animais foram mantidos no Biotério da Faculdade de Odontologia de Ribeirão Preto - USP durante os períodos experimentais, com alimentação e água ad libittum. Os mesmos foram periodicamente observados, com respeito à ocorrência de anormalidades locais, sistêmicas ou comportamentais.

Ao final de cada um dos períodos experimentais, 10 animais de cada grupo experimental (7, 21 e 63 dias) e 6 animais de cada grupo controle ( 7 e 21 dias) foram novamente anestesiados, para remoção cuidadosa do implante com os tecidos adjacentes (pele e tecido conjuntivo). Em seguida, os animais foram mortos por sobredose anestésica. Os tecidos removidos, os quais apresentavam forma retangular, foram fixados em solução de formol a $10 \%$ por 48 horas e submetidos ao processamento histotécnico de rotina. 


\section{Processamento histotécnico}

Os tecidos foram incluídos em parafina, sendo posteriormente efetuados cortes seriados de 4 a 5 micrometros de espessura, orientados paralelamente ao longo eixo dos tubos em cada espécime, que foram a seguir corados com Hematoxilina e Eosina.

\section{Análise microscópica}

Os espécimes foram analisados, por patologista calibrado, em microscópio Zeiss ${ }^{\circledR}$ binocular utilizando objetivas de 4, 10, 40 e 100X. Em seguida, efetuou-se análise descritiva, análise semi-quantitativa e análise quantitativa.

\section{1 - Análise microscópica descritiva}

Foi descrita a reação tecidual observada frente aos materiais testados e aos grupos controles nos diferentes períodos experimentais, sem especificar cada um dos espécimes, mas sim caracterizando o grupo analisado como um todo.

\section{2 - Análise microscópica semi-quantitativa}

Na análise semi-quantitativa do tecido periférico aos materiais testados e nos grupos controles foram atribuídos escores aos fenômenos referentes ao fibrosamento e infiltrado inflamatório, seguindo-se os critérios abaixo discriminados.

\section{A) Fibrosamento}

Levou-se em consideração o número e a densidade de fibras colágenas de permeio às células periféricas localizadas no tecido reacional circunjacente ao material testado. O fibrosamento foi classificado em 4 graus de severidade, de acordo com os seguintes escores:

-Escore 0: ausência de fibrosamento;

-Escore 1 (fibrosamento discreto): quando as fibras colágenas apresentavam-se individualizadas tal qual um tecido conjuntivo normal, entremeadas por espaços negativos indicativos de componentes não fibrosos de matriz extracelular;

-Escore 2 (fibrosamento moderado): quando em algumas áreas as fibras colágenas apresentavam-se individualizadas, mas com áreas alternadas de matriz extracelular eosinofílica sem formações lineares e onduladas típicas das mesmas; e 
-Escore 3 (fibrosamento intenso): quando as fibras colágenas apresentavam-se em meio a uma matriz extracelular eosinofílica, sem formações lineares e onduladas típicas, não permitindo uma individualização das mesmas.

\section{B) Infiltrado inflamatório}

Avaliou-se a concentração de neutrófilos polimorfonucleares de permeio ao tecido reacional peri-material. Esta concentração foi classificada em 4 graus de severidade (valores numéricos), de acordo com os seguintes escores:

- Escore 0: ausência de infiltrado inflamatório;

- Escore 1 (infiltrado inflamatório discreto): quando observava-se 1 a 10 neutrófilos no tecido reacional;

- Escore 2 (infiltrado inflamatório moderado): quando observava-se 11 a 20 neutrófilos no tecido reacional; e

- Escore 3 (infiltrado inflamatório intenso): quando observava-se mais de 21 neutrófilos no tecido reacional.

\section{C) Outros achados}

Registrou-se a ocorrência de fenômenos eventualmente encontrados como extravasamento de material além da abertura do tubo implantado, abscedeção e calcificação distrófica nos tecidos circunjacentes ao material testado.

\section{Análise Estatística}

Os dados foram analisados utilizando-se o programa estatístico Graph Pad Prism $4^{\odot}$ (Graph Pad Software In., San Diego, Califórnia, EUA). Comparações dos fenômenos fibrosamento e infiltrado inflamatório, no tecido periférico aos materiais testados e no grupo controle, foram efetuadas empregando o teste de Kruskal-Wallis. O nível de significância adotado foi de 5\%.

\section{3 - Análise microscópica quantitativa}

Foi medida a área $\left(\mu \mathrm{m}^{2}\right)$ (Figura 1) e a maior espessura $(\mu \mathrm{m})$ (Figura 2) do tecido reacional granulomatoso na extremidade-teste, em cada espécime dos diferentes grupos, onde essa medida foi possível de ser realizada. Com esse objetivo, as imagens microscópicas de cada espécime foram obtidas e analisadas no programa Image J 1.28u fornecido pelo National Institutes of Health, USA. 


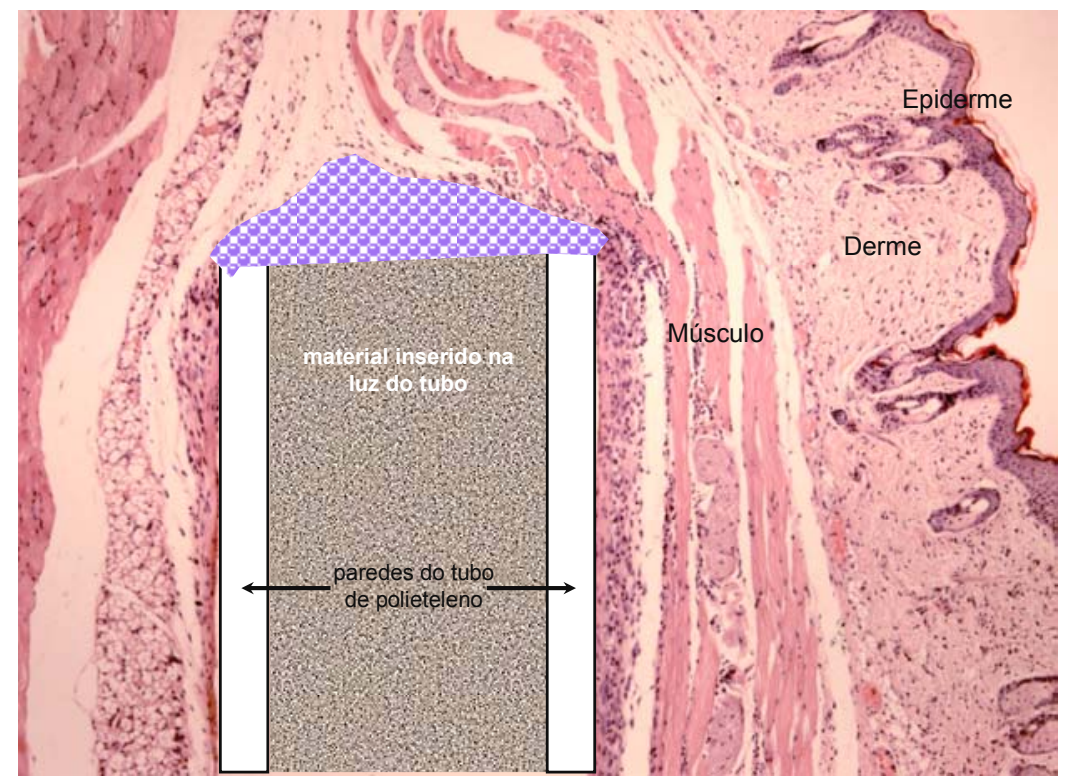

Figura 1 - Esquema ilustrativo dos componentes envolvidos na avaliação da reação tecidual frente à implantação de tubos de polietileno nos diferentes grupos. Na extremidade do tubo, na interface com o tecido conjuntivo vizinho, avaliou-se quantitativamente, para fins comparativos, a área ocupada pelo tecido reacional (textura azulada).

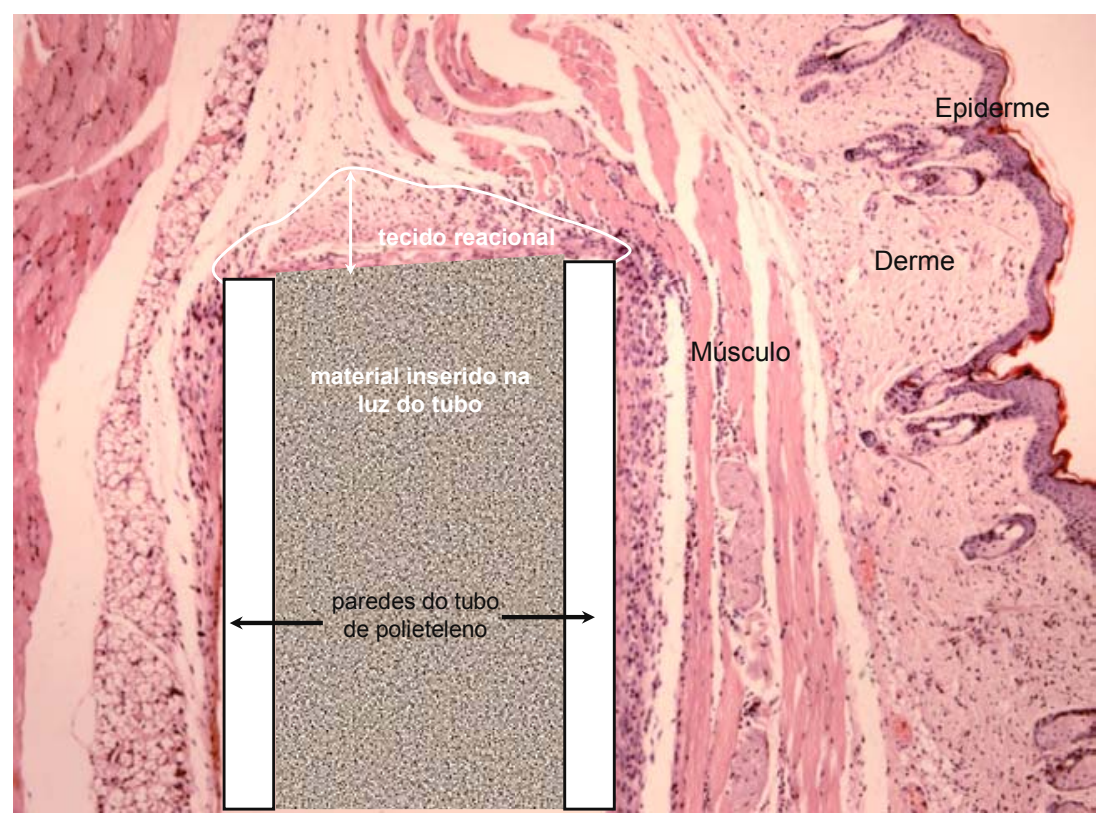

Figura 2 - Esquema ilustrativo dos componentes envolvidos na avaliação da reação tecidual frente à implantação de tubos de polietileno nos diferentes grupos. Na extremidade do tubo, na interface com o tecido conjuntivo vizinho, avaliou-se quantitativamente, para fins comparativos, a maior espessura do tecido reacional (seta branca). 


\section{Análise Estatística}

Os dados foram analisados utilizando-se o programa estatístico Graph Pad Prism $4^{\odot}$ (Graph Pad Software In., San Diego, Califórnia, EUA). Os parâmetros área e maior espessura do tecido reacional granulomatoso foram comparados empregando a análise de variância (ANOVA) e pós-teste de Tukey. O nível de significância adotado foi de $5 \%$. 


\section{Resultados}

\section{1) Atividade Antibacteriana in vitro - Teste de Difusão em Ágar}

A Figura 3 demonstra os halos de inibição do crescimento microbiano frente aos 5 microrganismos indicadores (Kocuria rhizophila, Enterococcus faecalis, Streptococcus mutans, Escherichia coli e Staphylococcus aureus), observados com os diferentes materiais obturadores de canais radiculares de dentes decíduos (cimento de óxido de zinco e eugenol, pasta Calen ${ }^{\circledR}$ espessada com óxido de zinco, cimento Sealapex ${ }^{\circledR}$ e cimento EndoREZ ${ }^{\mathrm{TM}}$ ) e os materiais controle (pasta Calen ${ }^{\circledR}$, digluconato de clorexidina a 1,0\% e água destilada), empregando o teste de difusão em ágar. 

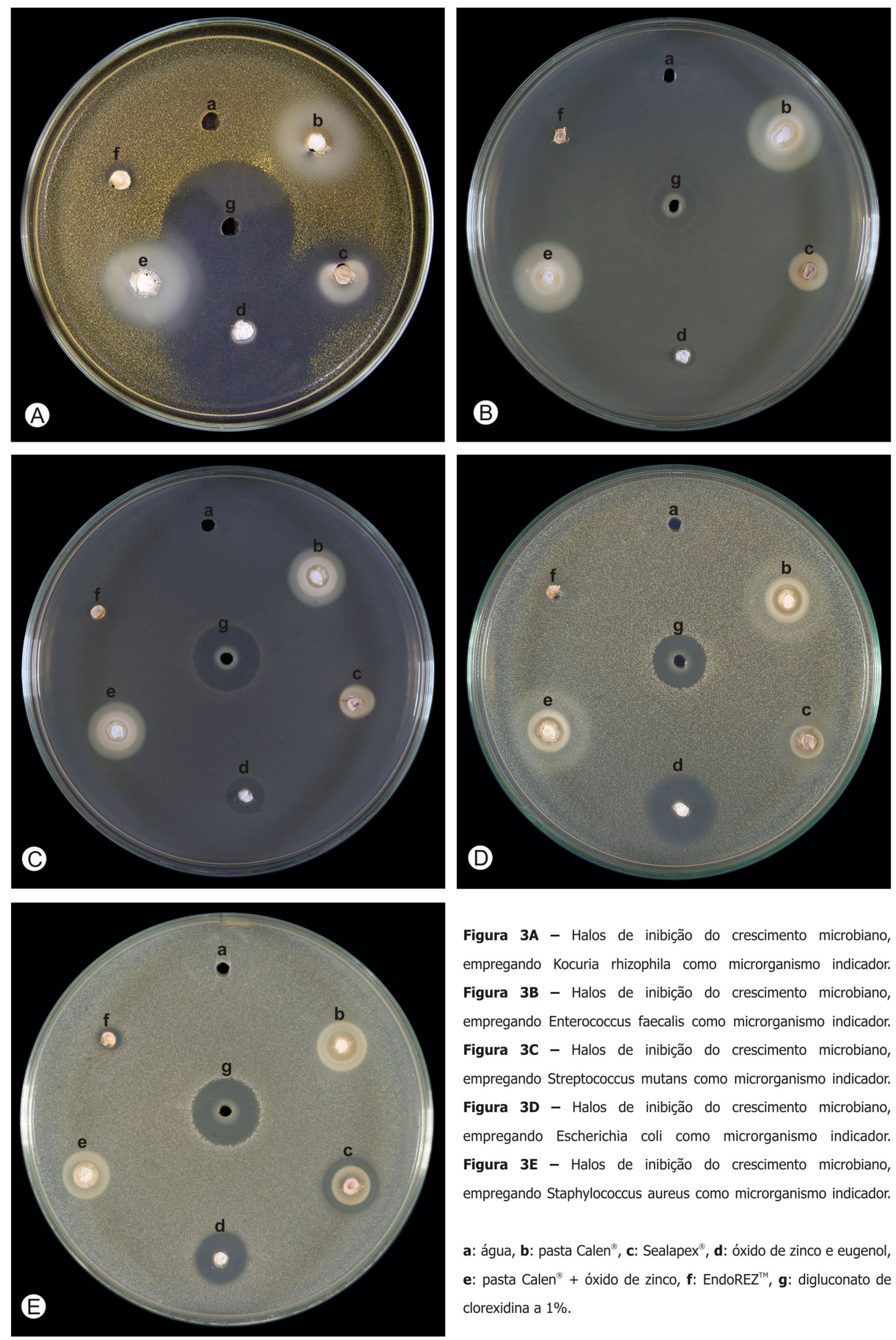

Figura 3A - Halos de inibição do crescimento microbiano, empregando Kocuria rhizophila como microrganismo indicador. Figura 3B - Halos de inibição do crescimento microbiano, empregando Enterococcus faecalis como microrganismo indicador. Figura 3C - Halos de inibição do crescimento microbiano, empregando Streptococcus mutans como microrganismo indicador. Figura 3D - Halos de inibição do crescimento microbiano, empregando Escherichia coli como microrganismo indicador. Figura 3E - Halos de inibição do crescimento microbiano, empregando Staphylococcus aureus como microrganismo indicador.

a: água, b: pasta Calen ${ }^{\circledast}$, $\mathbf{c}$ : Sealapex ${ }^{\circledast}$, d: óxido de zinco e eugenol, e: pasta Calen ${ }^{\circledast}+$ óxido de zinco, f: EndoREZ ${ }^{\top \mathrm{M}}, \mathbf{g}$ : digluconato de clorexidina a $1 \%$. 
A Tabela 4 mostra a média e o desvio padrão do diâmetro dos halos de inibição, em milímetros.

Tabela 4 - Média e desvio padrão dos halos de inibição (em milímetros)

\begin{tabular}{|c|c|c|c|c|c|c|c|c|c|c|}
\hline \multirow{2}{*}{ Materiais } & \multicolumn{2}{|c|}{ K. rhizophila } & \multicolumn{2}{|c|}{ E. faecalis } & \multicolumn{2}{|c|}{ S. mutans } & \multicolumn{2}{|c|}{ E. coli } & \multicolumn{2}{|c|}{ S. aureus } \\
\hline & Média & DP* & Média & DP* & Média & DP* & Média & DP* & Média & DP* \\
\hline Calen $^{\circledR}$ & 20,67 & 1,03 & 20,00 & 3,28 & 12,33 & 1,50 & 15,50 & 0,54 & 19,00 & 0,89 \\
\hline Calen $^{\circledR}+$ óxido de zinco & 21,33 & 0,51 & 22,00 & 0 & 12,67 & 1,96 & 16,00 & 0 & 17,00 & 0,89 \\
\hline Sealapex ${ }^{\circledR}$ & 20,67 & 1,03 & 13,00 & 1,10 & 11,00 & 0 & 12,00 & 0 & 20,00 & 0,9 \\
\hline Óxido de zinco e eugenol & 32,67 & 0,51 & 9,00 & 0 & 11,00 & 1,67 & 23,67 & 0,51 & 18,00 & 0,9 \\
\hline EndoREZ $^{\mathrm{TM}}$ & 7,00 & 0 & 0 & 0 & 0 & 0 & 0 & 0 & 8,00 & 0,89 \\
\hline Digluconato de clorexidina $1 \%$ & 31,50 & 0,54 & 18,00 & 0,63 & 24,17 & 1,47 & 19,33 & 0,51 & 23,00 & 0,63 \\
\hline Água destilada & 0 & 0 & 0 & 0 & 0 & 0 & 0 & 0 & 0 & 0 \\
\hline
\end{tabular}

A análise de variância evidenciou diferenças estatisticamente significantes $(p<0,0001)$ entre os halos de inibição ocasionados pelos diferentes materiais, para todos os microrganismos avaliados.

Com relação a Kocuria rhizophila, o pós-teste de Tukey, não evidenciou diferença estatisticamente significante entre a pasta Calen ${ }^{\circledR}$, a pasta Calen ${ }^{\circledR}$ espessada com óxido de zinco e o cimento Sealapex ${ }^{\circledR}(p>0,05)$, que apresentaram halos de inibição respectivamente de 20,67; 21,33 e 20,67mm de diâmetro, e nem entre o cimento de óxido de zinco e eugenol e o digluconato de clorexidina a $1 \%(p>0,05)$, os quais apresentaram halos de inibição respectivamente de 32,67 e $31,5 \mathrm{~mm}$ de diâmetro. O cimento EndoREZ ${ }^{\mathrm{TM}}$ ocasionou halos de inibição de $8 \mathrm{~mm}$ de diâmetro. Dessa maneira, quanto à atividade antibacteriana dos diferentes materiais frente a Kocuria rhizophila, pôde-se inferir que:

Cimento de óxido de zinco e eugenol = digluconato de clorexidina a 1\% > pasta Calen $^{\circledR}=$ pasta Calen $^{\circledR}$ espessada com óxido de zinco $=$ cimento Sealapex $^{\circledR}>$ cimento EndoREZ ${ }^{T M}>$ água destilada

O sinal de = foi empregado com significado de ausência de diferença estatisticamente significante, e não de igualdade.

Quando o microrganismo indicador foi o Enterococcus faecalis, os maiores halos de inibição foram ocasionados pela pasta Calen ${ }^{\circledR}$ espessada com óxido de zinco, seguido pela pasta Calen ${ }^{\circledR}$ e pelo digluconato de clorexidina a $1 \%$ (halos respectivamente de 22, 20 e $18 \mathrm{~mm}$ de diâmetro), não sendo observada diferença estatisticamente significante entre a pasta Calen ${ }^{\circledR}$ e a pasta Calen ${ }^{\circledR}$ espessada com óxido de zinco $(p>0,05)$, e nem entre a pasta Calen ${ }^{\circledR}$ e o digluconato de clorexidina a 
$1 \%(p>0,05)$. Houve diferença estatisticamente significante $(p<0,05)$ entre a pasta Calen ${ }^{\circledR}$ espessada com óxido de zinco (22mm de diâmetro) e o digluconato de clorexidina a $1 \%$ (18mm de diâmetro). O cimento EndoREZ ${ }^{\mathrm{TM}}$ e a água destilada não apresentaram atividade antibacteriana. 0 cimento Sealapex ${ }^{\circledR}$ e o cimento de óxido de zinco e eugenol apresentaram atividade antibacteriana intermediária (halos de inibição de 13 e 9mm de diâmetro), e diferentes entre si $(p<0,05)$. Dessa maneira, quanto à atividade antibacteriana dos diferentes materiais frente ao Enterococcus faecalis, pôdese inferir que:

Pasta Calen $^{\circledR}$ espessada com óxido de zinco $=$ pasta Calen $^{\circledR}=$ digluconato de clorexidina a $1 \%>$ cimento Sealapex ${ }^{\circledR}>$ cimento de óxido de zinco e eugenol > cimento EndoREZ ${ }^{T M}$ = água destilada

O sinal de = foi empregado com significado de ausência de diferença estatisticamente significante, e não de igualdade.

Pasta Calen ${ }^{\circledR}$ espessada com óxido de zinco > digluconato de clorexidina a $1 \%$

Nas placas semeadas com Streptococcus mutans não foi observada diferença estatisticamente significante entre a pasta Calen ${ }^{\circledR}$, a pasta Calen ${ }^{\circledR}$ espessada com óxido de zinco, o cimento Sealapex ${ }^{\circledR}$ e o cimento de óxido de zinco e eugenol ( $p>0,05)$, os quais ocasionam halos de inibição respectivamente de 12,33; 12,67; 11 e $11 \mathrm{~mm}$ de diâmetro. O digluconato de clorexidina a $1 \%$ ocasionou os maiores halos de inibição (24,17mm de diâmetro) com diferença estatisticamente significante entre ele e os outros grupos $(p<0,05)$. O cimento EndoREZ ${ }^{\text {TM }}$ e a água destilada não apresentaram atividade antimicrobiana. Dessa maneira, quanto à atividade antibacteriana dos diferentes materiais frente ao Streptococcus mutans, pôde-se inferir que:

Digluconato de clorexidina a $1 \%$ > pasta Calen ${ }^{\circledR}$ espessada com óxido de zinco = pasta Calen $^{\circledR}=$ cimento Sealapex ${ }^{\circledR}=$ cimento de óxido de zinco e eugenol > cimento EndoREZ ${ }^{T M}$ = água destilada

O sinal de = foi empregado com significado de ausência de diferença estatisticamente significante, e não de igualdade.

Já com relação a Escherichia coli não foi observada diferença estatisticamente significante entre a pasta Calen ${ }^{\circledR}$ e a pasta Calen ${ }^{\circledR}$ espessada com óxido de zinco ( $p>0,05)$, que ocasionaram halos de inibição respectivamente de 15,5 e $16 \mathrm{~mm}$ de diâmetro, e nem entre o cimento EndoREZ ${ }^{\mathrm{TM}}$ e a água destilada $(p>0,05)$, os quais não apresentaram atividade antibacteriana. O cimento de óxido de zinco e eugenol e o digluconato de clorexidina a $1 \%$ ocasionaram os maiores halos de inibição 
(23,67 e 19,33mm de diâmetro, respectivamente), com diferença estatisticamente significante entre eles $(p<0,05)$. Dessa maneira, quanto à atividade antibacteriana dos diferentes materiais frente a Escherichia coli, pôde-se inferir que:

Cimento de óxido de zinco e eugenol > digluconato de clorexidina a $1 \%$ > pasta

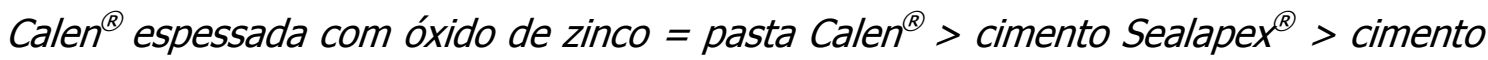
EndoREZ ${ }^{T M}$ = água destilada

O sinal de = foi empregado com significado de ausência de diferença estatisticamente significante, e não de igualdade.

Com relação ao Staphylococcus aureus, o diâmetro dos halos de inibição ocasionados pelos materiais testados, em ordem decrescente, foram: $23 \mathrm{~mm}$ para o digluconato de clorexidina a $1 \%, 20 \mathrm{~mm}$ para o cimento Sealapex ${ }^{\circledR}, 19 \mathrm{~mm}$ para a pasta Calen ${ }^{\circledR}, 18 \mathrm{~mm}$ para o cimento de óxido de zinco e eugenol, $17 \mathrm{~mm}$ para a pasta Calen ${ }^{\circledR}$ espessada com óxido de zinco e $8 \mathrm{~mm}$ para o cimento EndoREZ ${ }^{\mathrm{TM}}$. Não foram observadas diferenças estatisticamente significantes entre a pasta Calen ${ }^{\circledR}$ e o cimento Sealapex ${ }^{\circledR}(p>0,05)$, e entre a pasta Calen ${ }^{\circledR}$ e o cimento de óxido de zinco e eugenol $(p>0,05)$ e nem entre a pasta Calen ${ }^{\circledR}$ espessada com óxido de zinco e o cimento de óxido de zinco e eugenol ( $p>0,05)$. Houve diferença estatisticamente significante $(p<0,05)$ entre o cimento Sealapex ${ }^{\circledR}$ (halo de $20 \mathrm{~mm}$ de diâmetro) e o cimento de óxido de zinco e eugenol (halo de $18 \mathrm{~mm}$ de diâmetro), e entre a pasta Calen ${ }^{\circledR}$ (halo de $19 \mathrm{~mm}$ de diâmetro) e a pasta Calen ${ }^{\circledR}$ espessada com óxido de zinco (halo de $17 \mathrm{~mm}$ de diâmetro). Dessa maneira, quanto à atividade antibacteriana dos diferentes materiais frente ao Staphylococcus aureus, pôde-se inferir que:

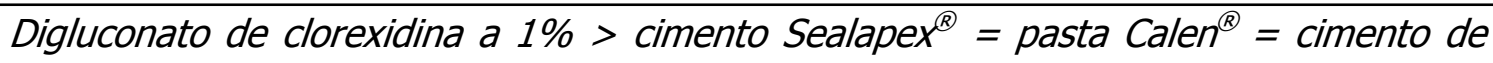
óxido de zinco e eugenol = pasta Calen ${ }^{\circledR}$ espessada com óxido de zinco > cimento EndoREZ ${ }^{T M}>$ água destilada

O sinal de = foi empregado com significado de ausência de diferença estatisticamente significante, e não de igualdade.

Cimento Sealapex ${ }^{\circledR}>$ cimento de óxido de zinco e eugenol

Pasta Calen ${ }^{\circledR}>$ pasta Calen ${ }^{\circledR}$ espessada com óxido de zinco

Para melhor compreensão, a comparação entre a atividade antibacteriana, apenas dos materiais obturadores de canais radiculares de dentes decíduos testados (cimento de óxido de zinco e eugenol, pasta Calen ${ }^{\circledR}$ espessada com óxido de zinco, cimento Sealapex ${ }^{\circledR}$ e cimento EndoREZ ${ }^{\mathrm{TM}}$ ), com relação a cada um dos microrganismos indicadores, pode ser sintetizada da seguinte forma: 
- Kocuria rhizophila: cimento de óxido de zinco e eugenol > pasta Calen ${ }^{\circledR}$ espessada com óxido de zinco = cimento Sealapex ${ }^{\circledR}>$ cimento EndoREZ $^{T M}$

- Enterococcus faecalis: pasta Calen ${ }^{\circledR}$ espessada com óxido de zinco > cimento Sealapex ${ }^{\circledR}>$ cimento de óxido de zinco e eugenol > cimento EndoREZ ${ }^{T M}$

- Streptococcus mutans: pasta Calen ${ }^{\circledR}$ espessada com óxido de zinco = cimento Sealapex ${ }^{\circledR}=$ cimento de óxido de zinco e eugenol > cimento EndoREZ ${ }^{T M}$

- Escherichia coli: cimento de óxido de zinco e eugenol > pasta Calen ${ }^{\circledR}$ espessada com óxido de zinco > cimento Sealapex ${ }^{\circledR}>$ cimento EndoREZ ${ }^{T M}$

- Staphylococcus aureus: cimento Sealapex ${ }^{\circledR}>$ cimento de óxido de zinco e eugenol = da pasta Calen ${ }^{\circledR}$ espessada com óxido de zinco > cimento EndoREZ ${ }^{T M}$

O sinal de = foi empregado com significado de ausência de diferença estatisticamente significante, e não de igualdade.

De maneira geral, independentemente do microrganismo avaliado, pôde-se inferir que, em ordem decrescente, o cimento de óxido de zinco e eugenol foi o material obturador de canal radicular de dentes decíduos que apresentou a maior atividade antibacteriana, seguido pela pasta Calen ${ }^{\circledR}$ espessada com óxido de zinco, pelo cimento Sealapex ${ }^{\circledR}$ e pelo cimento EndoREZ ${ }^{\mathrm{TM}}$. 


\section{2) Compatibilidade Tecidual in vivo - Estudo em Camundongos Isogênicos}

\section{Análise Microscópica Descritiva}

Grupo I - Pasta Calen ${ }^{\circledR}$ espessada com óxido de zinco - 7 dias (Figura 4)

A reação tecidual periférica ao material se caracterizou por uma faixa de tecido eosinofílico na interface do mesmo com o tecido circunjacente. Representou uma faixa estreita e homogênea. Na face interna desse tecido observaram-se fragmentos do material. Subjacente notou-se infiltração de muitos macrófagos, com focos de fibroblastos bem organizados, com organização capsular e áreas com células gigantes multinucleadas inflamatórias. Permeando a reação tecidual notaram-se vários neutrófilos polimorfonucleares. O fibrosamento notado foi focal e sem caracterizar uma cápsula contínua e bem organizada.

\section{Grupo II - Cimento EndoREZ TM - 7 dias (Figura 5)}

$\mathrm{Na}$ interface com o material a reação caracterizou-se pelo edema e área hialinizada irregular permeada por fragmentos celulares. Subjacente a essa área notouse a presença de macrófagos e fibroblastos jovens em área de matriz extracelular minimamente colagenizada e associada a edema. Notou-se grande número de neutrófilos de permeio ao tecido reacional. Na periferia observou-se também grande quantidade de vasos neoformados. O material apresentou-se morfologicamente com áreas irregulares basofílicas e negativas, permeadas por material granular acastanhado.

\section{Grupo III - Cimento Sealapex ${ }^{\circledR}-7$ dias (Figura 6)}

$\mathrm{Na}$ interface com o material testado notava-se uma área hialina, homogênea mas com fragmentação celular e discreto edema. Subjacente havia muitos neutrófilos juntamente com macrófagos e fibroblastos jovens. Em alguns espécimes o fibrosamento discreto destacava-se com ausência do mesmo em outros espécimes. Não se observaram células gigantes multinucleadas inflamatórias. O material se apresentou na forma granular acastanhado, com formações cristalóides pequenas, irregulares e refringentes. Em alguns espécimes (3), o material se apresentou também nas margens laterais dos tubos-teste. 
Grupo IV - Cimento de óxido de zinco e eugenol - 7 dias (Figura 7)

$\mathrm{Na}$ interface com o material o tecido reacional não apresentou área eosinofílica, as células em contato com o material eram caracterizadas morfologicamente como neutrófilos, em grande número, macrófagos e até fibroblastos. O fibrosamento geralmente discreto apresentava uma clara organização capsular. Entre os fibroblastos notavam-se os macrófagos e os neutrófilos. O edema presente era discreto. As células gigantes multinucleadas inflamatórias estavam em pequeno número e eram irregulares. O material apresentava-se amorfo, acastanhado e granular.

\section{Grupo V - Pasta Calen ${ }^{\circledR}$ espessada com óxido de zinco - 21 dias (Figura 8)}

O grupo $\mathrm{V}$ apresentou-se com fibrosamento moderado, de nítida organização capsular na interface com o material. Entre os fibroblastos notou-se um grande número de macrófagos, discreto edema e número de neutrófilos variando entre discreto e moderado. Os elementos celulares estavam contidos em uma espessura moderada constituída pelo tecido reacional frente ao material. Algumas células gigantes inflamatórias multinucleadas puderam ser visualizadas. O material agora apresentava-se de forma mais homogênea e eosinofílica, com discreto material granular distribuído irregularmente nos fragmentos observados. Em relação aos 7 dias evidenciou-se um aumento do fibrosamento, uma melhora na organização capsular, redução do edema e da população leucocitária, especialmente de macrófagos.

\section{Grupo VI - Cimento EndoREZ ${ }^{\mathrm{M}}$ - 21 dias (Figura 9)}

Neste período experimental o fibrosamento, na reação tecidual frente ao EndoREZ ${ }^{\mathrm{TM}}$, foi maior e se apresentava mais organizado. A espessura do tecido reacional aumentou em relação aos 7 dias, com aumento, em alguns espécimes, da população celular de macrófagos e fibroblastos. O número de neutrófilos variou entre discreto e moderado e o edema reduziu-se. Na interface entre o material e o tecido reacional ainda se observou uma banda hialina estreita e pouco celularizada. Eventualmente notaram-se células gigantes multinucleadas inflamatórias.

\section{Grupo VII - Cimento Sealapex ${ }^{\circledR}-21$ dias (Figura 10)}

Aos 21 dias a reação tecidual ao Sealapex ${ }^{\circledR}$ revelou-se com espessura relativamente fina e um fibrosamento discreto a moderado muito bem organizado. 0 edema e a resposta neutrofílica mostraram-se reduzidos. Os macrófagos quando exuberantes em número apresentavam-se evidenciados pela presença intracitoplasmática de partículas do material. Em 4 espécimes observou-se que, na 
reação tecidual granulomatosa do tipo corpo estranho induzida pelo Sealapex ${ }^{\circledR}$, muitos macrófagos continham o material em seu interior, em forma de partículas escuras e refringentes (se assemelhando a partículas de ionômero de vidro). Nas células gigantes multinucleadas inflamatórias em seu citoplasma, essas partículas também eram abundantemente observadas. Em boa parte dos macrófagos observados o citoplasma continha as partículas e eram vacuolizados.

Grupo VIII - Cimento de óxido de zinco e eugenol - 21 dias (Figura 11)

O tecido reacional frente ao cimento de óxido de zinco e eugenol, após 21 dias, apresentava-se com espessura moderada e bem organizada do ponto de vista capsular. Os fibroblastos apresentavam-se bem definidos, de forma fusiforme e em continuidade com as fibras colágenas. O número de neutrófilos era reduzido. Em alguns espécimes o material foi observado no interior do citoplasma dos macrófagos presentes. Eventuais células gigantes puderam ser observadas.

Grupo IX - Pasta Calen ${ }^{\circledR}$ espessada com óxido de zinco - 63 dias (Figura 12)

A espessura da reação tecidual, aos 63 dias frente à pasta Calen ${ }^{\circledR}$ espessada com óxido de zinco, revelou-se fina e muito bem organizada. 0 fibrosamento variou entre moderado e discreto, e quando discreto, se assemelhava ao dos tecidos circunjacentes. A quantidade de neutrófilos e de células gigantes inflamatórias multinucleadas foi bastante reduzida.

\section{Grupo X-Cimento EndoREZ ${ }^{\mathrm{M}}$ - 63 dias (Figura 13)}

A resposta tecidual frente ao cimento EndoREZ ${ }^{\mathrm{TM}}$ caracterizou-se por apresentar uma grande quantidade de neutrófilos como parte da reação ao material. Ao contrário dos 7 e 21 dias após a implantação do EndoREZ ${ }^{\mathrm{TM}}$, aos 63 dias notou-se em 5 espécimes material no interior de macrófagos, com aparência granular e escura. Ao mesmo tempo o material que se via no interior do tubo aos 7 e 21 dias, agora não estava mais presente. Supostamente a reação tecidual, celular e exsudativa, tenha conseguido dissolvê-lo e/ou fagocitá-lo. O fibrosamento não era uniforme e organizado de forma regular. A espessura ora era fina em alguns locais, ora era mais espessada. As células gigantes multinucleadas inflamatórias estavam presentes em pequeno número.

Grupo XI - Cimento Sealape $x^{\circledR}-63$ dias (Figura 14)

O fibrosamento moderado e bem organizado permitiu uma uniformidade na reação tecidual ao Sealapex ${ }^{\circledR}$, após 63 dias. Os macrófagos presentes fagocitaram o 
material em abundância e se distribuíram difusamente no tecido reacional. Os neutrófilos estavam presentes em grande número. Algumas células gigantes multinucleadas inflamatórias estavam presentes. Parte do material ainda se encontrava no tubo com suas estruturas cristalóides birrefringentes. A espessura do tecido reacional revelou-se fina, neste período.

Grupo XII - Cimento de óxido de zinco e eugenol - 63 dias (Figura 15)

A espessura do tecido reacional foi menor que aos 7 e 21 dias e 0 fibrosamento discreto e bem organizado. Não se observaram macrófagos fagocitando o material. Algumas células gigantes multinucleadas inflamatórias estavam presentes. Os neutrófilos encontravam-se em quantidade considerável e maior que aos 21 dias.

\section{Grupo XIII - Tubo Vazio - 7 dias (Figura 16)}

A reação tecidual na abertura vazia do tubo estava representada por presença marcante de fibroblastos permeados por macrófagos e eventuais neutrófilos. Não se detectou células gigantes multinucleadas inflamatórias nesta região. Contrastando com esta área de extremidade vazia, nas paredes laterais do tubo de polietileno a resposta tecidual apresentava-se bem menos exuberante, com poucas células gigantes multinucleadas inflamatórias e macrófagos na sua superfície, bem como tecido reacional bem próximo à morfologia do tecido conjuntivo fibroso, quanto ao seu grau de fibrosamento e organização estrutural.

\section{Grupo XIV - Tubo Vazio - 21 dias (Figura 17)}

$\mathrm{O}$ tecido reacional na extremidade aberta do tubo apresentou-se menos exuberante em sua espessura, quando comparado com o período de 7 dias, porém o grau de fibrosamento foi menor. Os macrófagos presentes estavam associados a eventuais neutrófilos e células gigantes multinucleadas inflamatórias. Comparativamente às paredes laterais do tubo implantado, a resposta na abertura vazia do tubo era muito maior em sua espessura e celularidade. 
Figura 4 - Grupo I - Aspectos microscópicos da reação do tecido conjuntivo subcutâneo de camundongos frente ao tubo polietileno (TP) preenchido com a pasta Calen ${ }^{\circledR}$ espessada com óxido de zinco aos 7 dias.

Observam-se fragmentos do material (MT), macrófagos (MO), fibroblastos organizados em feixes (setas em B), neutrófilos polimorfonucleares (NT) e células gigantes multinucleadas inflamatórias (CG). Notam-se áreas de necrose por coagulação (NC). (MM=músculo esquelético; DM=derme) (H.E.; 4X em A, 10X em B, 40X em C e 100X em D).

Figura 5 - Grupo II - Aspectos microscópicos da reação do tecido conjuntivo subcutâneo de camundongos frente ao tubo polietileno (TP) preenchido com o cimento EndoREZ $^{\circledR}$ aos 7 dias.

Observam-se fragmentos do material (MT), macrófagos distribuídos aleatoriamente (MO), fibroblastos eventualmente organizados em feixes (setas em B) e neutrófilos polimorfonucleares (NT) associados à fragmentação nuclear (FN) ou cariorexe na área

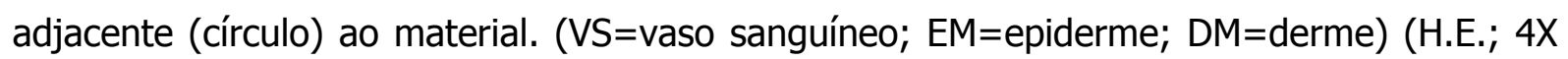
em $A, 10 X$ em $B, 40 X$ em C e 100X em D). 
Grupo 1: 7 dias - Calen + Óxido de Zinco
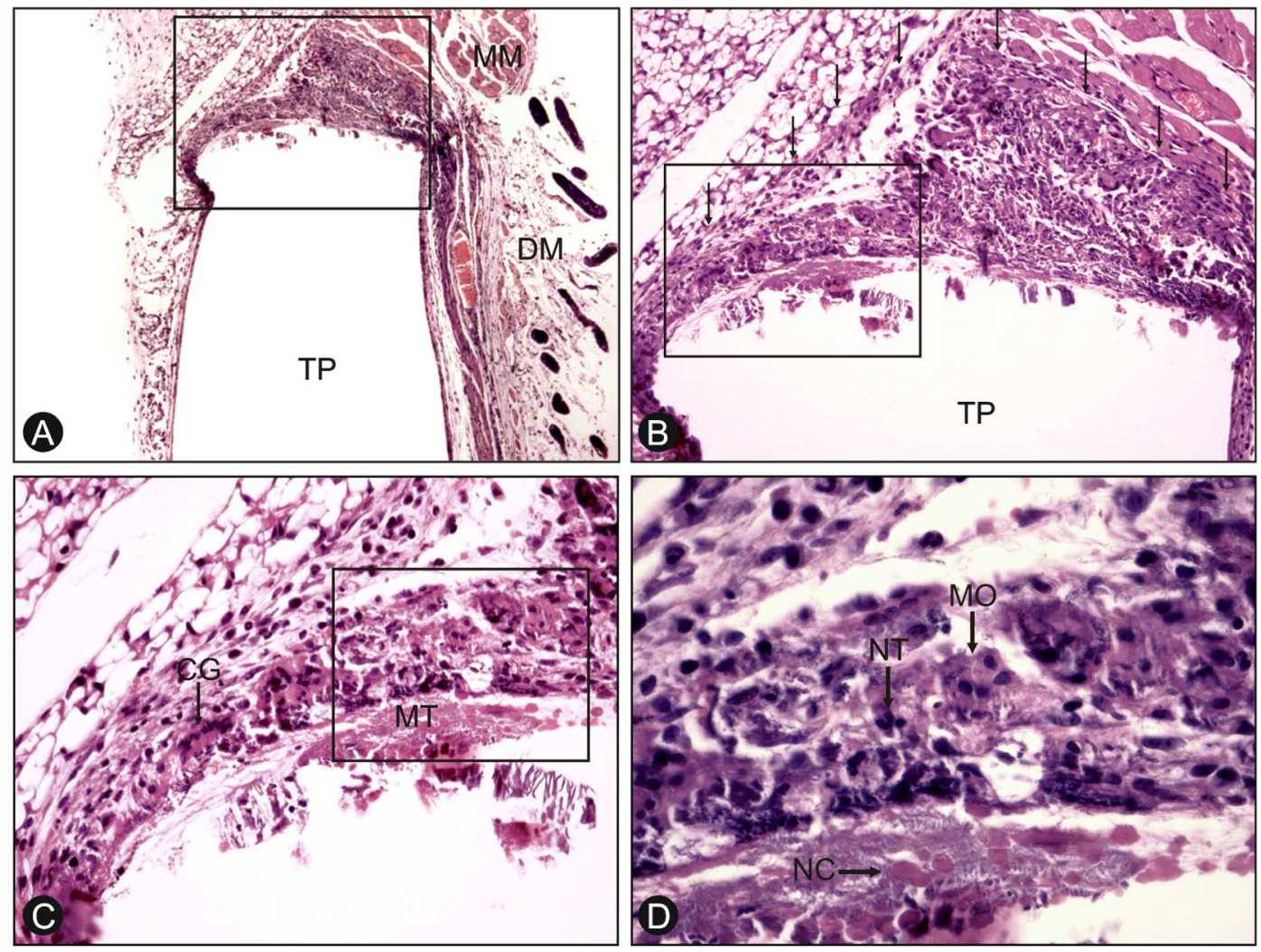

Grupo 2: 7 dias - Endorez
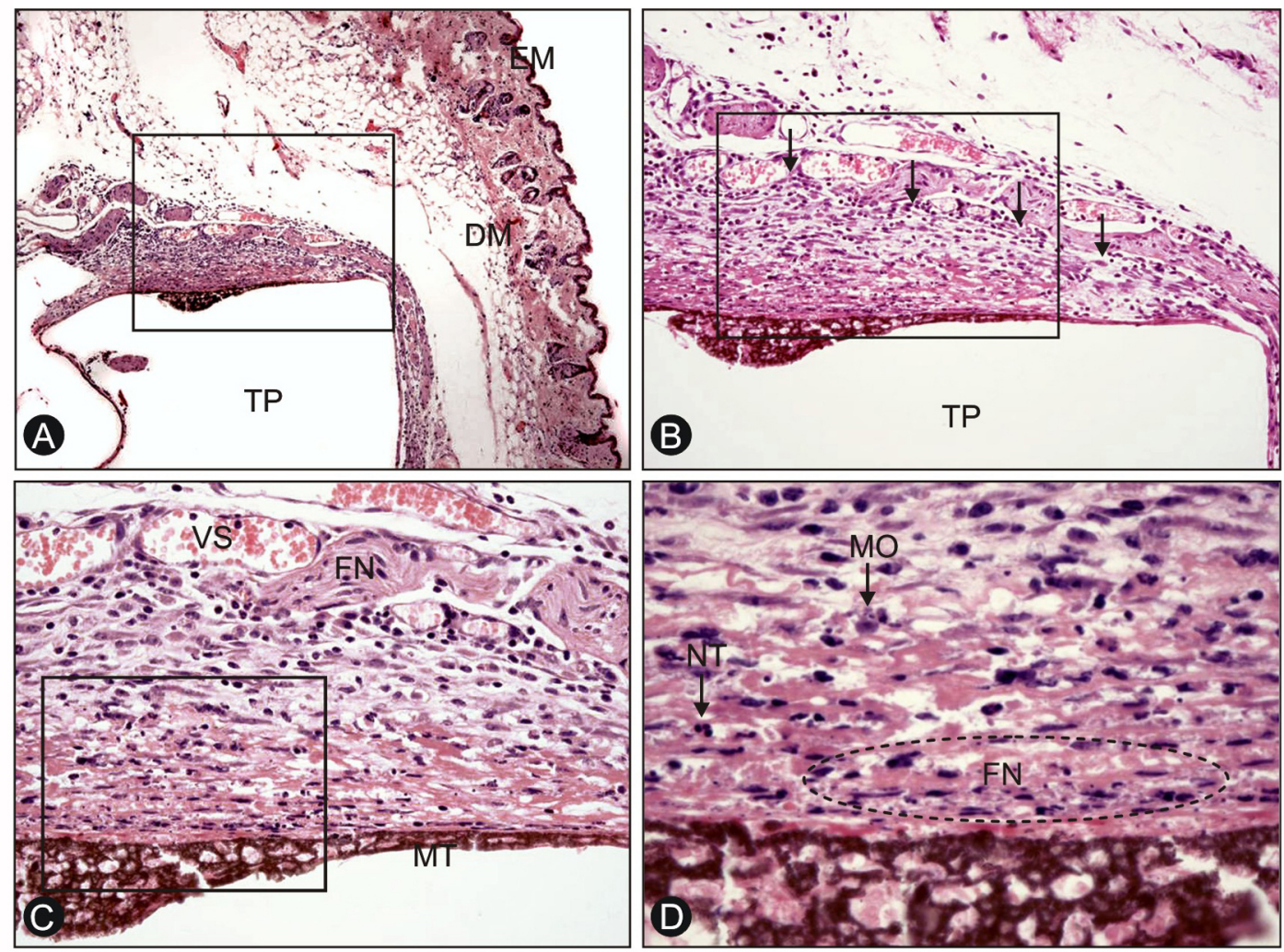
Figura 6 - Grupo III - Aspectos microscópicos da reação do tecido conjuntivo subcutâneo de camundongos frente ao tubo polietileno (TP) preenchido com o cimento Sealapex ${ }^{\circledR}$ aos 7 dias.

Observam-se o material testado em grande quantidade (MT), macrófagos (MO) mais perifericamente localizados, poucos fibroblastos sutilmente organizados em delicados feixes (setas em B), neutrófilos polimorfonucleares (NT) localizados principalmente na interface com o material e ausência de células gigantes multinucleadas inflamatórias. Notam-se áreas de necrose por coagulação (NC) na interface com o material. No material nota-se estruturas cristalóides (FC). (MM=músculo esquelético; $\mathrm{DM}=$ derme) (H.E.; 4X em A, 10X em B, 40X em C e 100X em D).

Figura 7 - Grupo IV - Aspectos microscópicos da reação do tecido conjuntivo subcutâneo de camundongos frente ao tubo polietileno (TP) preenchido com o cimento de óxido de zinco e eugenol aos 7 dias.

Os fragmentos de material estão ausentes. Observam-se macrófagos (MO) e neutrófilos (NT) na interface com o material testado. Os fibroblastos (FB) estão bem organizados em feixes (setas em B) e C. O tecido reacional está diretamente relacionado com o músculo esquelético (MM) e este com o tecido adiposo adjacente (TA). (H.E.; 4X em A, 10X em B, 40X em C e 100X em D). 
Grupo 3: 7 dias - Sealapex
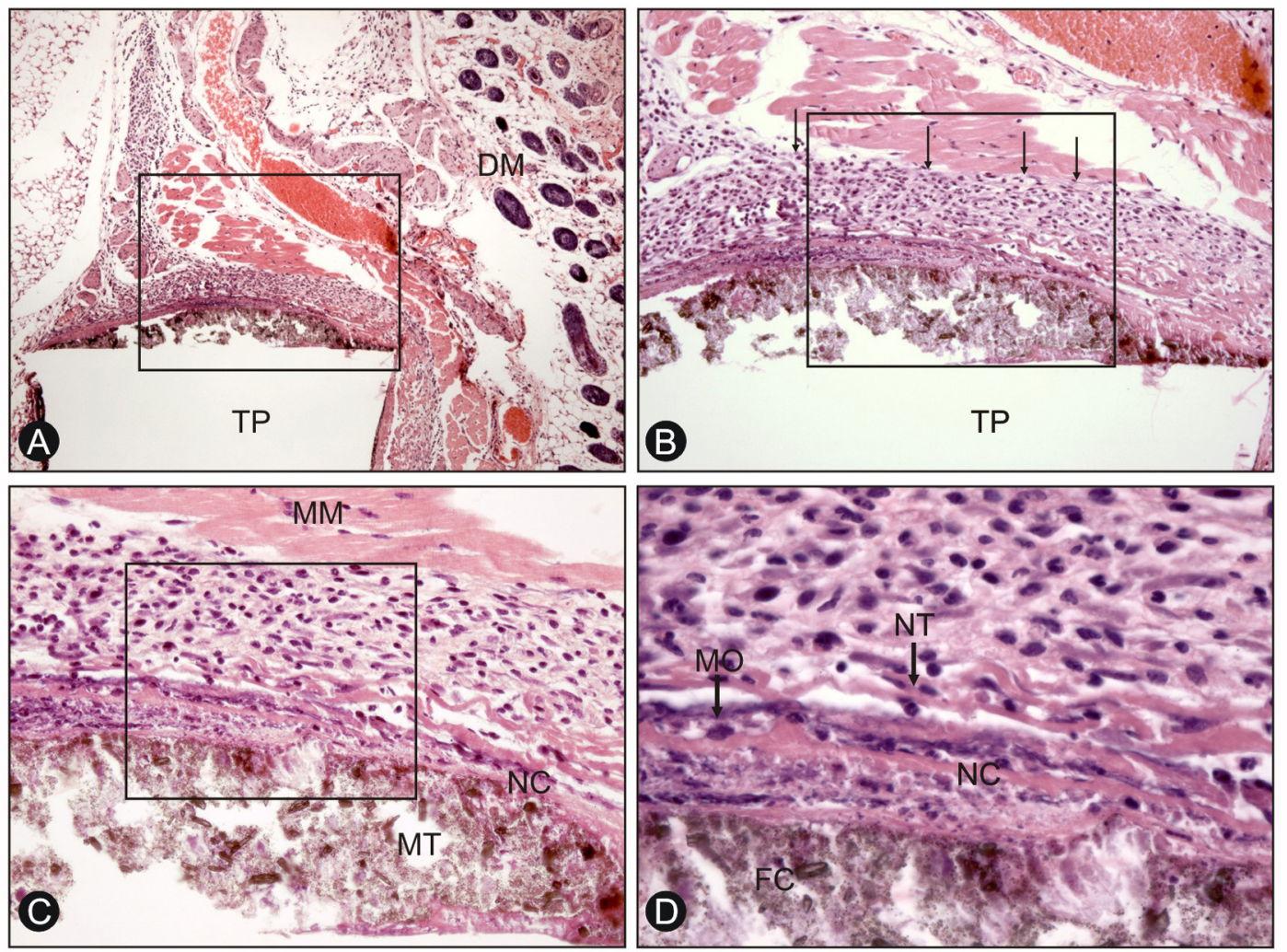

Grupo 4: 7 dias - Óxido de Zinco e Eugenol
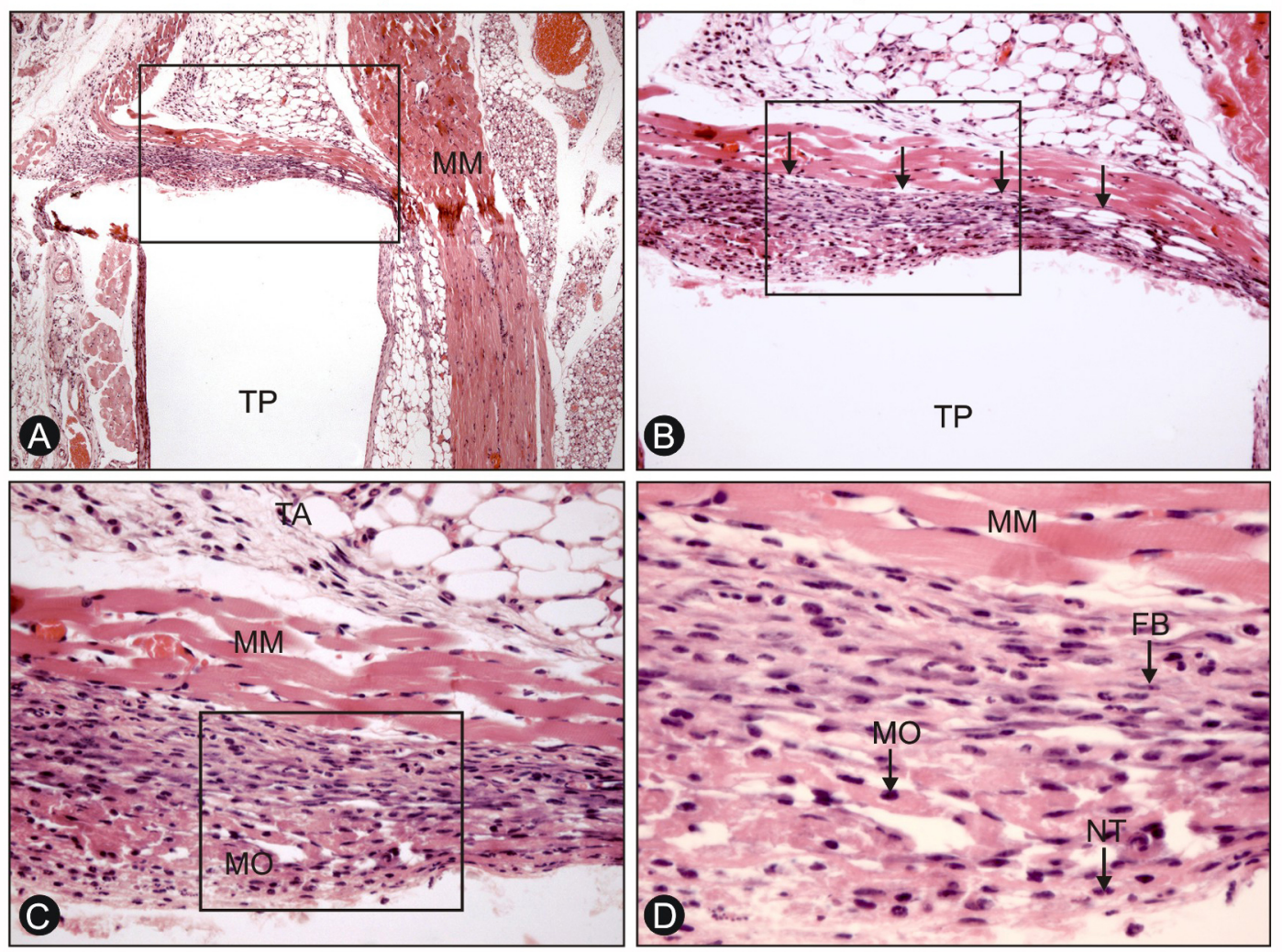
Figura 8 - Grupo V - Aspectos microscópicos da reação do tecido conjuntivo subcutâneo de camundongos frente ao tubo polietileno (TP) preenchido com a pasta Calen ${ }^{\circledR}$ espessada com óxido de zinco aos 21 dias.

Nota-se um fibrosamento delicado, mas organizado em feixes colágenos bem definidos e com nítida organização capsular na interface com o material (setas em B). Entre os fibroblastos (FB) têm-se macrófagos (MO), discreto edema representado pelos espaços negativos e eventuais neutrófilos (NT). O material apresenta-se de forma homogênea e eosinofílica, com discreto material (MT) granular distribuído irregularmente nos fragmentos observados em B, C e D. (MM=músculo esquelético; TA=tecido adiposo; NR=filete neural; VS=vaso sanguíneo) (H.E.; 4X em A, 10X em B, 40X em C e 100X em D).

Figura 9 - Grupo VI - Aspectos microscópicos da reação do tecido conjuntivo subcutâneo de camundongos frente ao tubo polietileno (TP) preenchido com o cimento EndoREZ $^{\circledR}$ aos 21 dias.

Nota-se um fibrosamento mais espesso e mais distante do material, mas organizado em feixes colágenos com organização capsular irregular (setas em B). Entre os fibroblastos (FB) têm-se muitos macrófagos (MO), discreto edema representado pelos espaços negativos e neutrófilos (NT). Tem-se ainda fragmentação nuclear. O material apresenta-se de forma rendilhada com material (MT) granular distribuído irregularmente em fragmentos eosinofílicos em B, C e D. (MM=músculo esquelético; TA=tecido adiposo; VS=vaso sanguíneo; DM=derme) (H.E.; 4X em A, 10X em B, 40X em C e 100X em D). 
Grupo 5: 21 dias - Calen + óxido de zinco
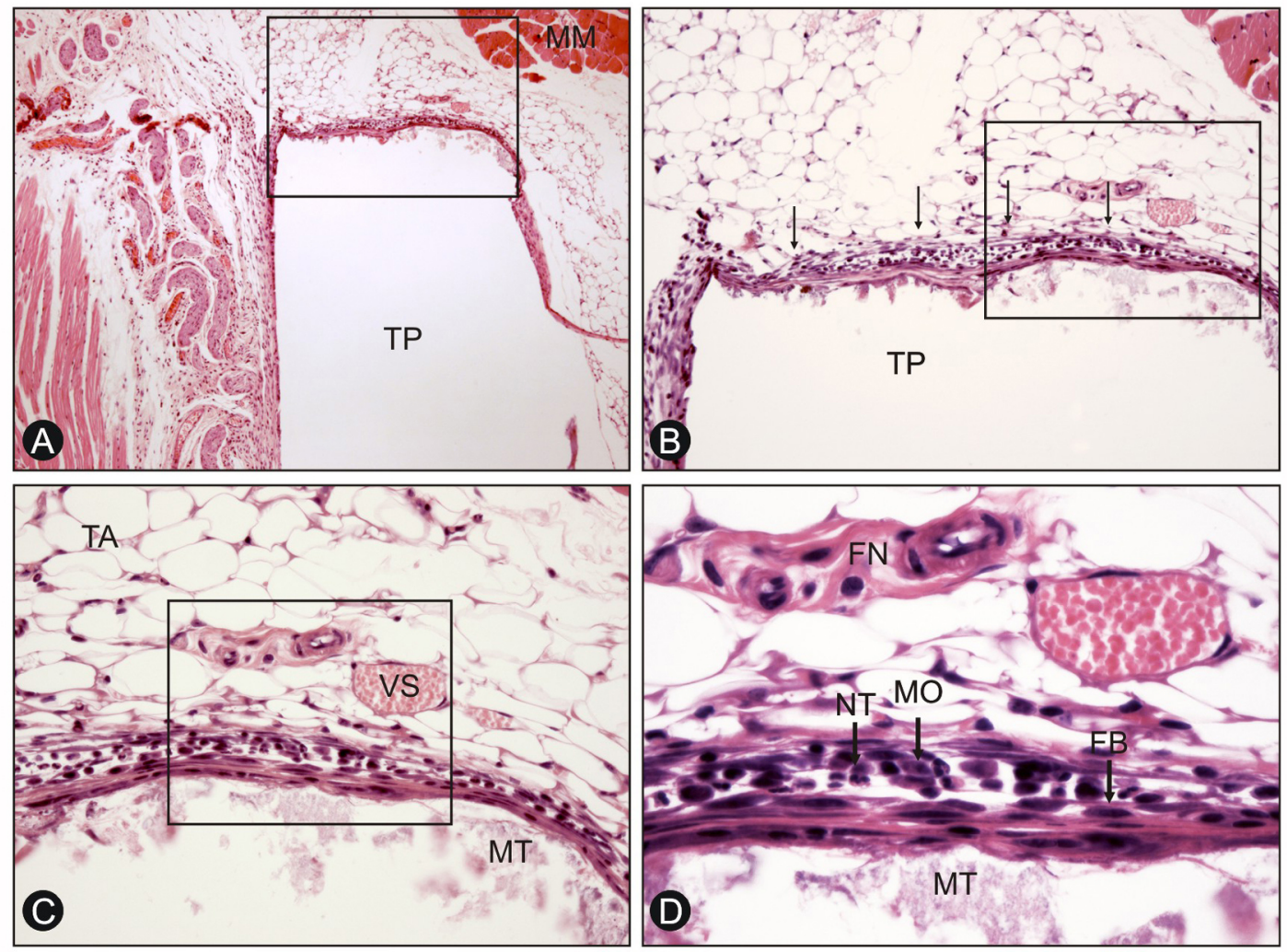

Grupo 6: 21 dias - Endorez
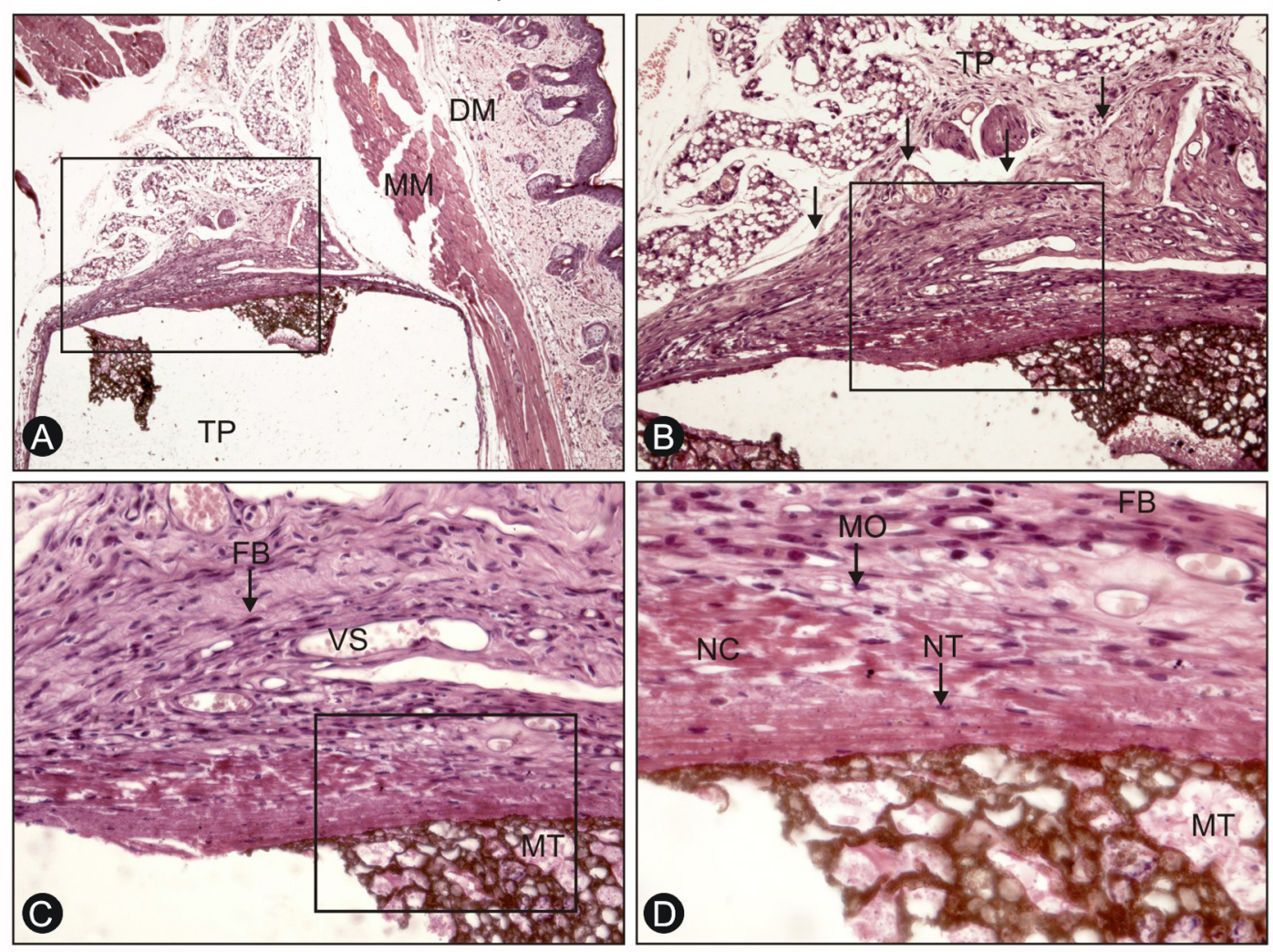
Figura 10 - Grupo VII - Aspectos microscópicos da reação do tecido conjuntivo subcutâneo de camundongos frente ao tubo polietileno (TP) preenchido com o cimento Sealapex ${ }^{\circledR}$ aos 21 dias.

Observa-se um fibrosamento delicado com feixes colágenos curtos e permeados entre os fibroblastos, assumindo a organização capsular à distância do material (setas em B). Entre os fibroblastos têm-se macrófagos (MO), discreto edema representado pelos espaços negativos e raros neutrófilos (NT). O material não permaneceu no tubo. Na interface com o material notam-se principalmente macrófagos e fibroblastos. (MM=músculo esquelético; $\mathrm{DM}=$ derme) (H.E.; 4X em A, 10X em B, 40X em C e 100X em D).

Figura 11 - Grupo VIII - Aspectos microscópicos da reação do tecido conjuntivo subcutâneo de camundongos frente ao tubo polietileno (TP) preenchido com o cimento de óxido de zinco e eugenol aos 21 dias.

O tecido reacional apresenta espessura de fina e bem organizada do ponto de vista capsular. Os fibroblastos (FB) apresentam-se bem definidos, de forma fusiforme e em continuidade com as fibras colágenas delicadas (setas em C). Os neutrófilos (NT) estão em número reduzido e os macrófagos (MO) presentes na interface com o material (MT). Eventuais células gigantes multinucleadas inflamatórias podem ser observadas na interface com material com a sua morfologia muito achatada em D. (MM=músculo esquelético; $\mathrm{DM}=$ derme) (H.E.; 4X em A, 10X em B, 40X em C e 100X em D). 
Grupo 7: 21 dias - Sealapex
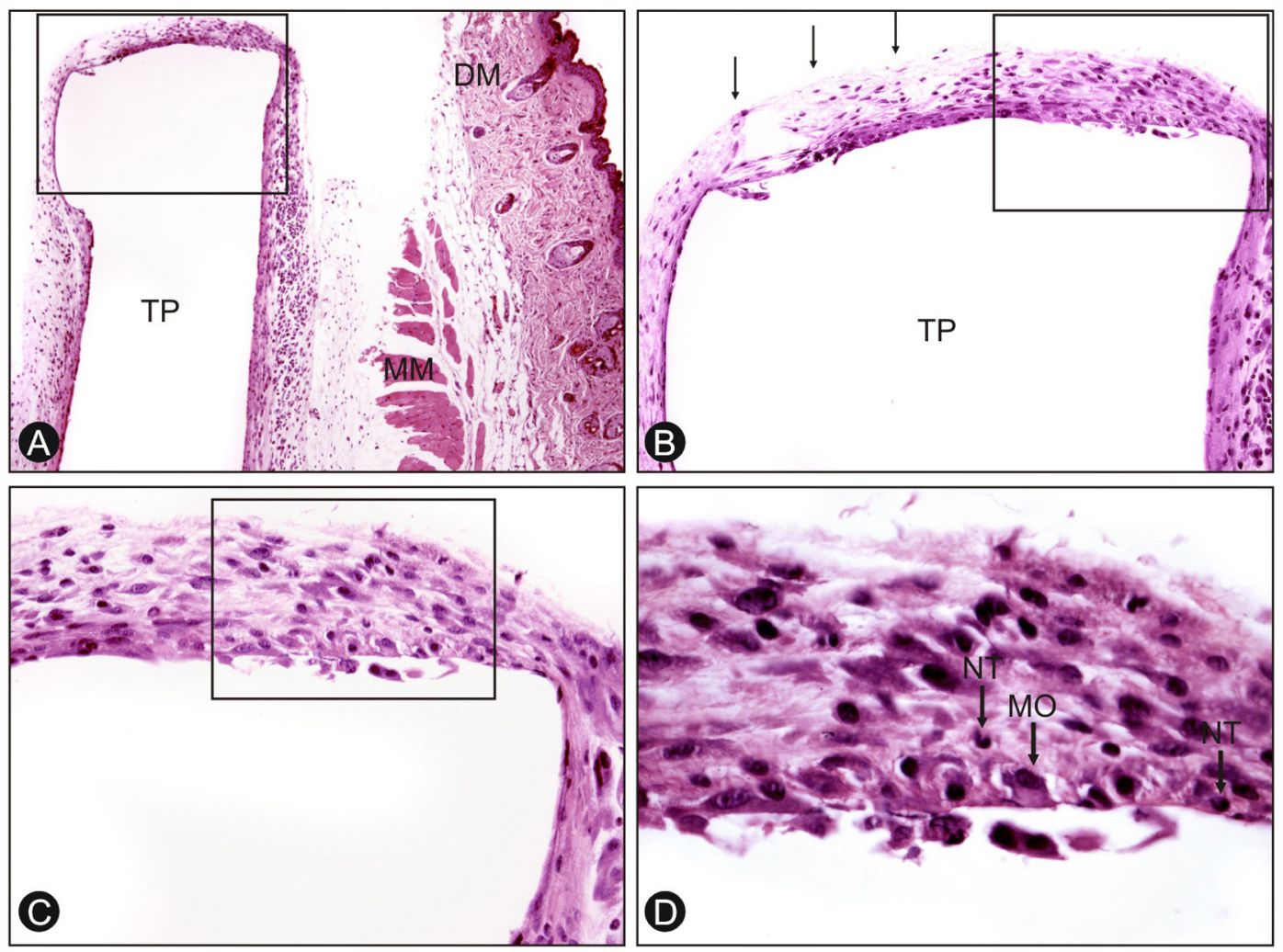

Grupo 8: 21 dias - Óxido de Zinco e Eugenol
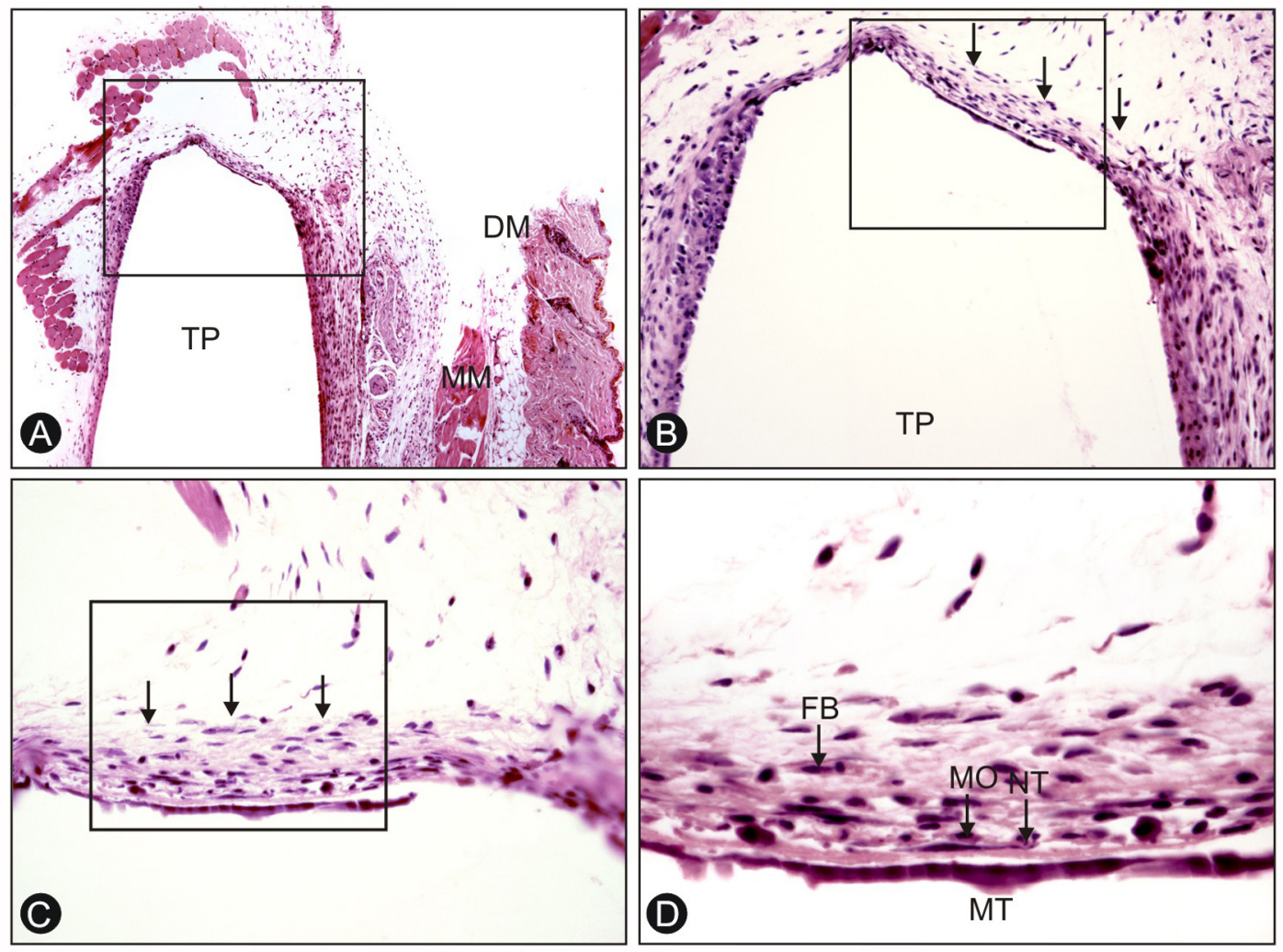
Figura 12 - Grupo IX - Aspectos microscópicos da reação do tecido conjuntivo subcutâneo de camundongos frente ao tubo polietileno (TP) preenchido com a pasta Calen ${ }^{\circledR}$ acrescida de óxido de zinco aos 63 dias.

Nota-se um fibrosamento delicado e pouco organizado em feixes colágenos definidos e curtos, sem uma nítida organização capsular na interface com o material (setas em B). Entre os fibroblastos (FB) têm-se macrófagos (MO), inclusive junto ao material. Há discreto edema representado pelos espaços negativos, bem como eventuais neutrófilos (NT). (MM=músculo esquelético; DM=derme) (H.E.; 4X em A, 10X em B, 40X em C e 100X em D).

Figura 13 - Grupo X - Aspectos microscópicos da reação do tecido conjuntivo subcutâneo de camundongos frente ao tubo polietileno (TP) preenchido com o cimento EndoREZ $^{\circledR}$ aos 63 dias.

$\mathrm{Na}$ interface com o material ausente nestes cortes, nota-se muitos macrófagos (MO), em parte com material granular do cimento no citoplasma (círculo), denotando diretamente a propriedade fagocitável do mesmo. O fibrosamento não apresenta-se uniforme, sendo minimamente organizado como cápsula fibrosa (seta em B) com poucos fibroblastos (FB). 0 tecido reacional apresenta pequena espessura e edema bem definido. Observa-se uma acentuada presença de neutrófilos (NT). O material no interior do tubo não pode ser observado, o mesmo ocorrendo com as células gigantes inflamatórias multinucleadas. (MM=músculo esquelético) (H.E.; 4X em A, 10X em B, 40X em C e 100X em D). 
Grupo 9: 63 dias - Calen + Óxido de Zinco
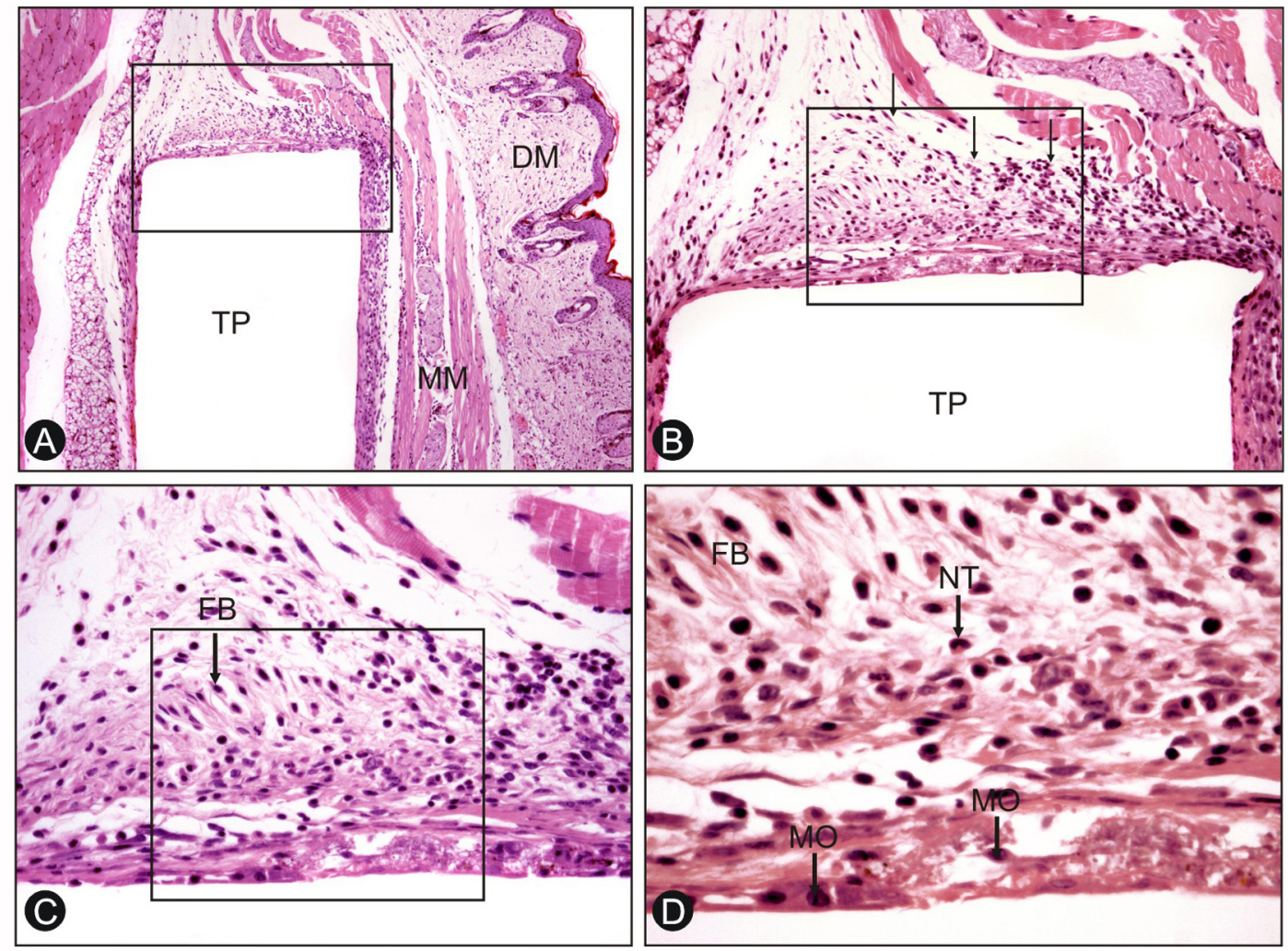

Grupo 10: 63 dias - Endorez
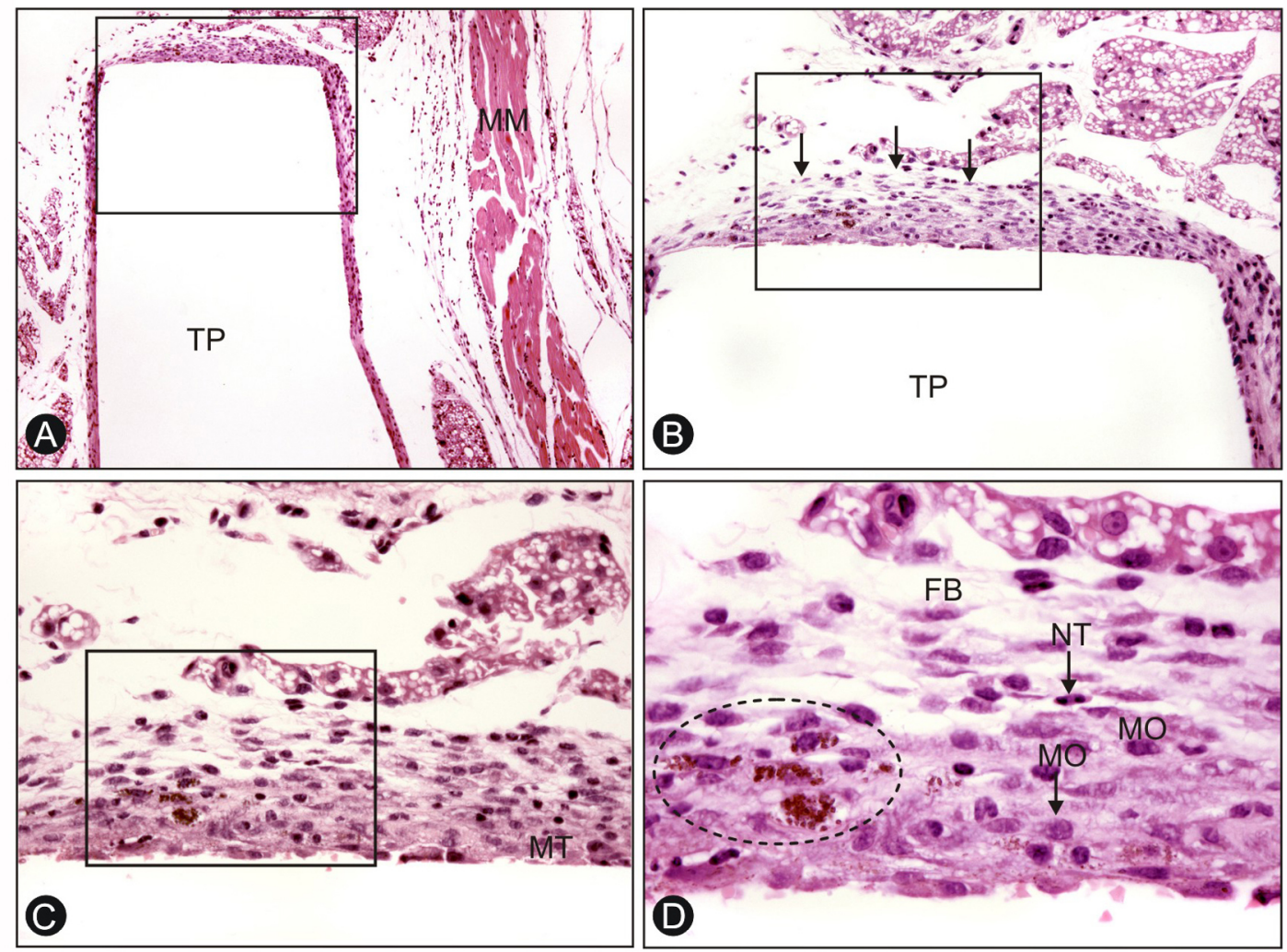
Figura 14 - Grupo XI - Aspectos microscópicos da reação do tecido conjuntivo subcutâneo de camundongos frente ao tubo polietileno (TP) preenchido com o cimento Sealapex ${ }^{\circledR}$ aos 63 dias.

O fibrosamento bem organizado e moderado (setas em B), com fibroblastos bem caracterizados (FB) contrasta com as exuberantes células gigantes multinucleadas inflamatórias (CG). Os macrófagos imediatamente em contato com o material (MT) contêm o mesmo em abundância em seu interior. Os neutrófilos (NT) eventualmente estão presentes ( $M M=$ músculo esquelético). (H.E.; 4X em A, 10X em B, 40X em C e 100X em D).

Figura 15 - Grupo XII - Aspectos microscópicos da reação do tecido conjuntivo subcutâneo de camundongos frente ao tubo polietileno (TP) preenchido com o cimento de óxido de zinco e eugenol aos 63 dias.

O fibrosamento na interface com o material (MT) apresenta-se bem organizado e de espessura pequena, mas na periferia com os tecidos adjacentes sua densidade e organização lembra o tecido conjuntivo fibroso em continuidade (setas em B). De permeio, notam-se os macrófagos (MO) e neutrófilos (NT). (DM=derme) (H.E.; 4X em A, 10X em B, 40X em C e 100X em D). 
Grupo 11: 63 dias - Sealapex
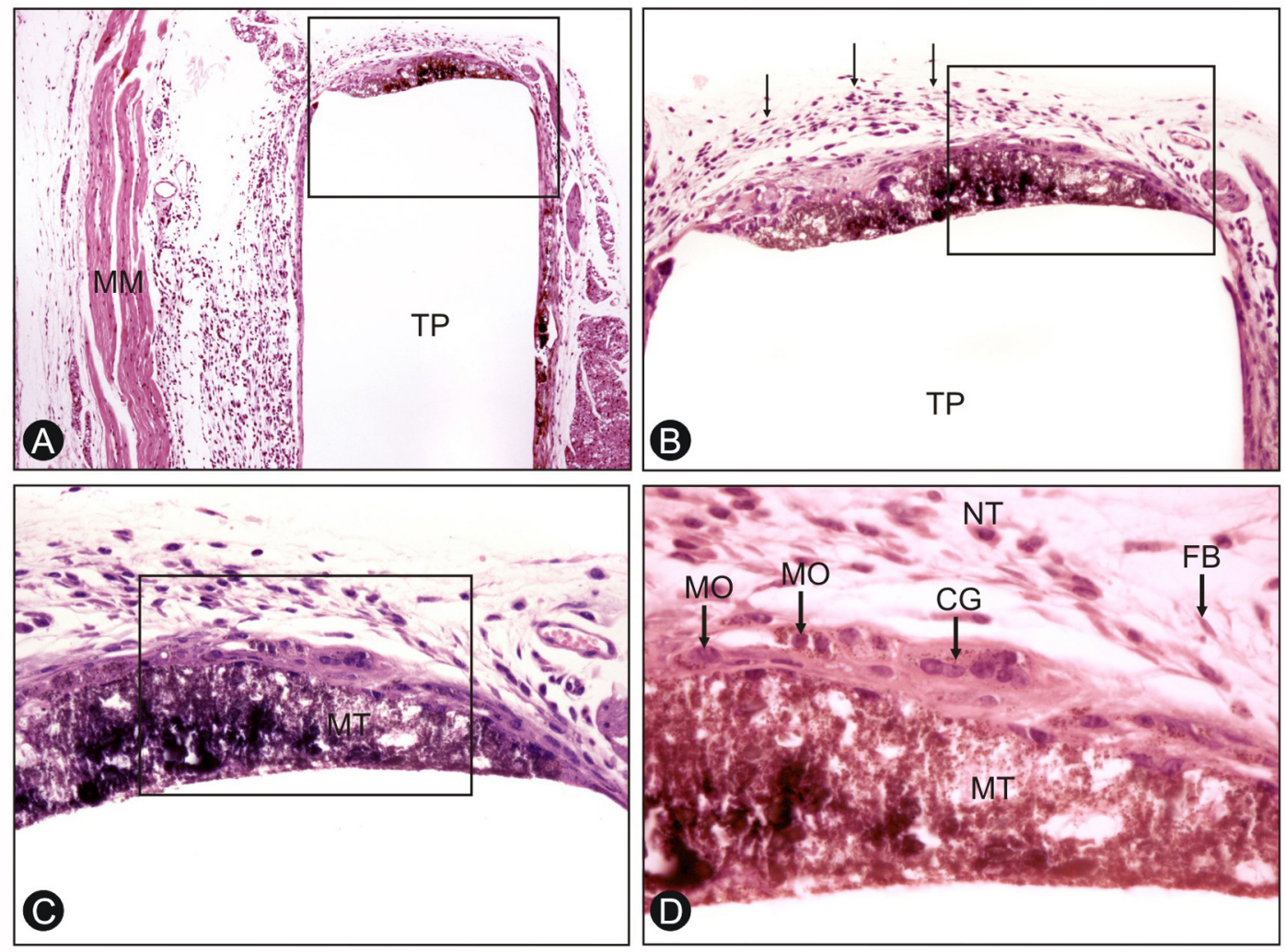

Grupo 12: 63 dias - Óxido de Zinco e Eugenol
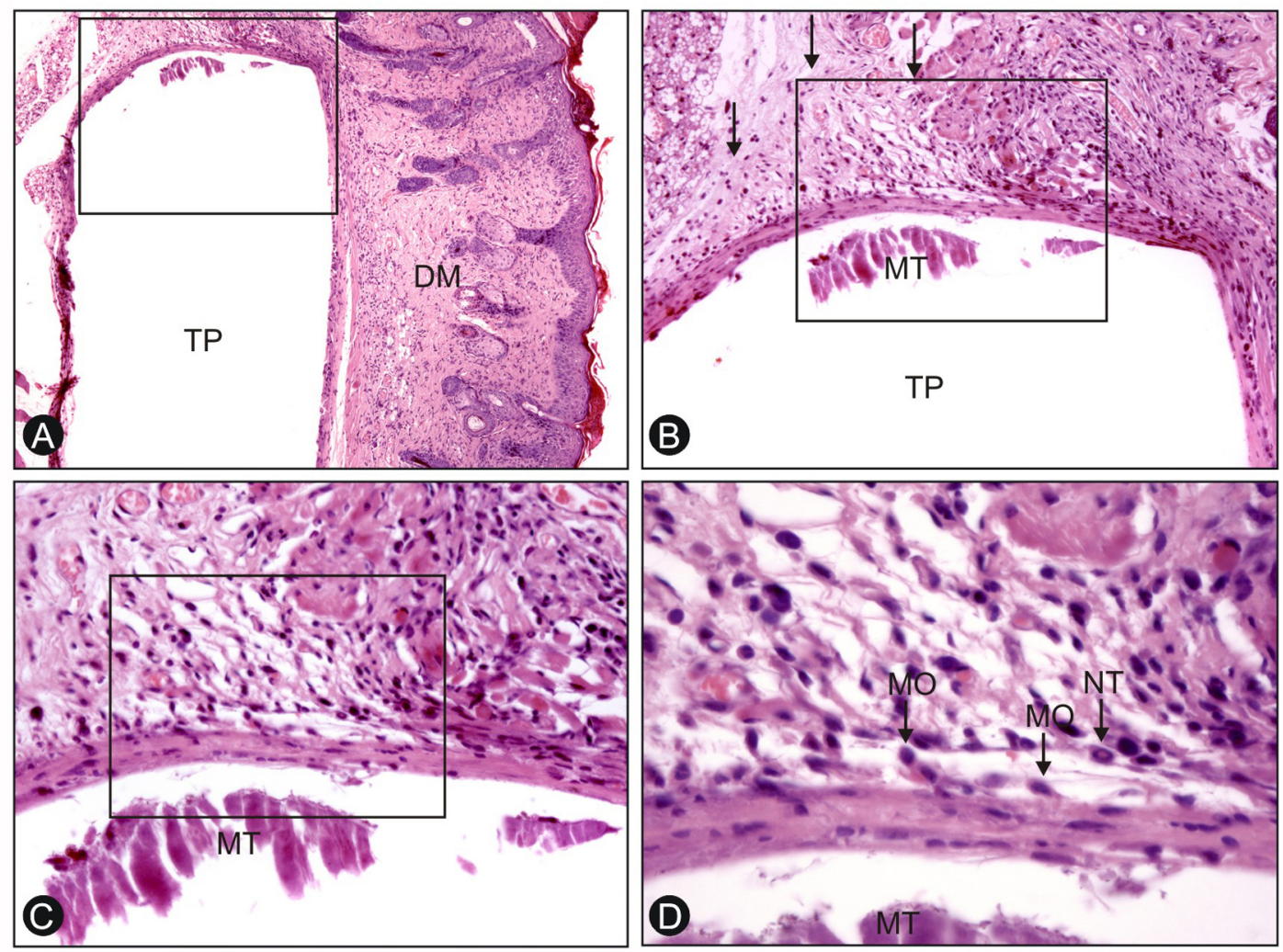
Figura 16 - Grupo XIII - Aspectos microscópicos da reação do tecido conjuntivo subcutâneo de camundongos frente ao tubo polietileno (TP) vazio aos 7 dias.

O tecido reacional na abertura do tubo vazio é moderadamente espesso, mas ricamente celularizado por fibroblastos (FB) e macrófagos (MO). O infiltrado inflamatório é discreto e caracterizado por poucos neutrófilos (NT). O fibrosamento é discreto e bem organizado (setas em D). Exsudato inflamatório (EI) está presente na luz do tubo. (MM=músculo esquelético; TA=tecido adiposo; $\mathrm{DM}=$ derme) (H.E.; 4X em A, 10X em B, 40X em C e 100X em D).

Figura 17 - Grupo XIV - Aspectos microscópicos da reação do tecido conjuntivo subcutâneo de camundongos frente ao tubo polietileno (TP) vazio aos 21 dias.

A espessura do tecido reacional na extremidade aberta do tubo apresenta-se pouco exuberante, com discreto grau de fibrosamento e moderada quantidade de fibroblastos (FB) permeados por macrófagos (MO) além de eventuais neutrófilos e células gigantes multinucleadas inflamatórias (CG). Comparativamente às paredes laterais do tubo implantado, a resposta na abertura vazia do tubo é maior em sua espessura e celularidade (em A e B) (H.E.; 4X em A, 10X em B, 40X em C e 100X em D). 
Grupo 13: 7 dias - Tubo Vazio
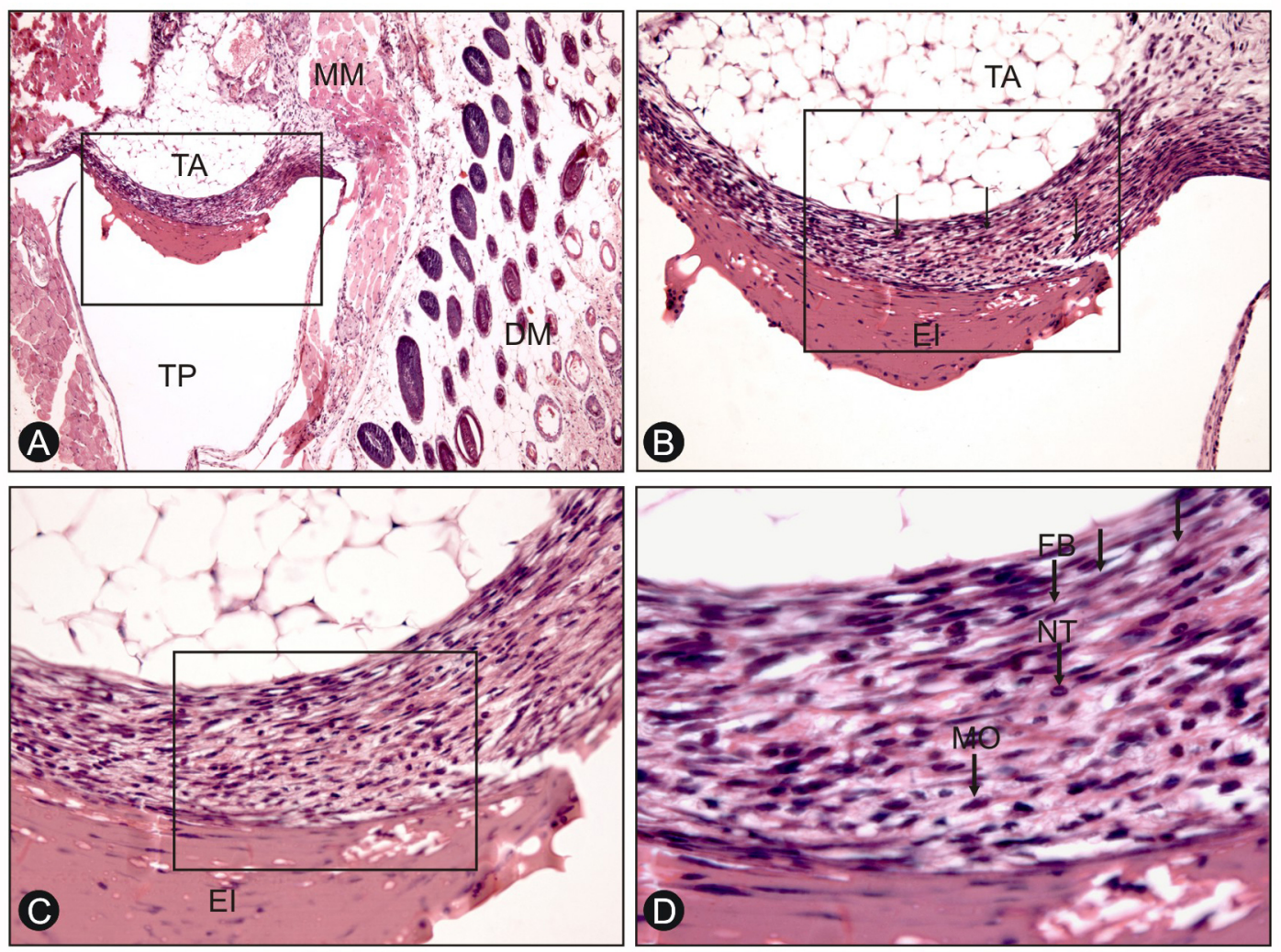

Grupo 14: 21 dias - Tubo Vazio
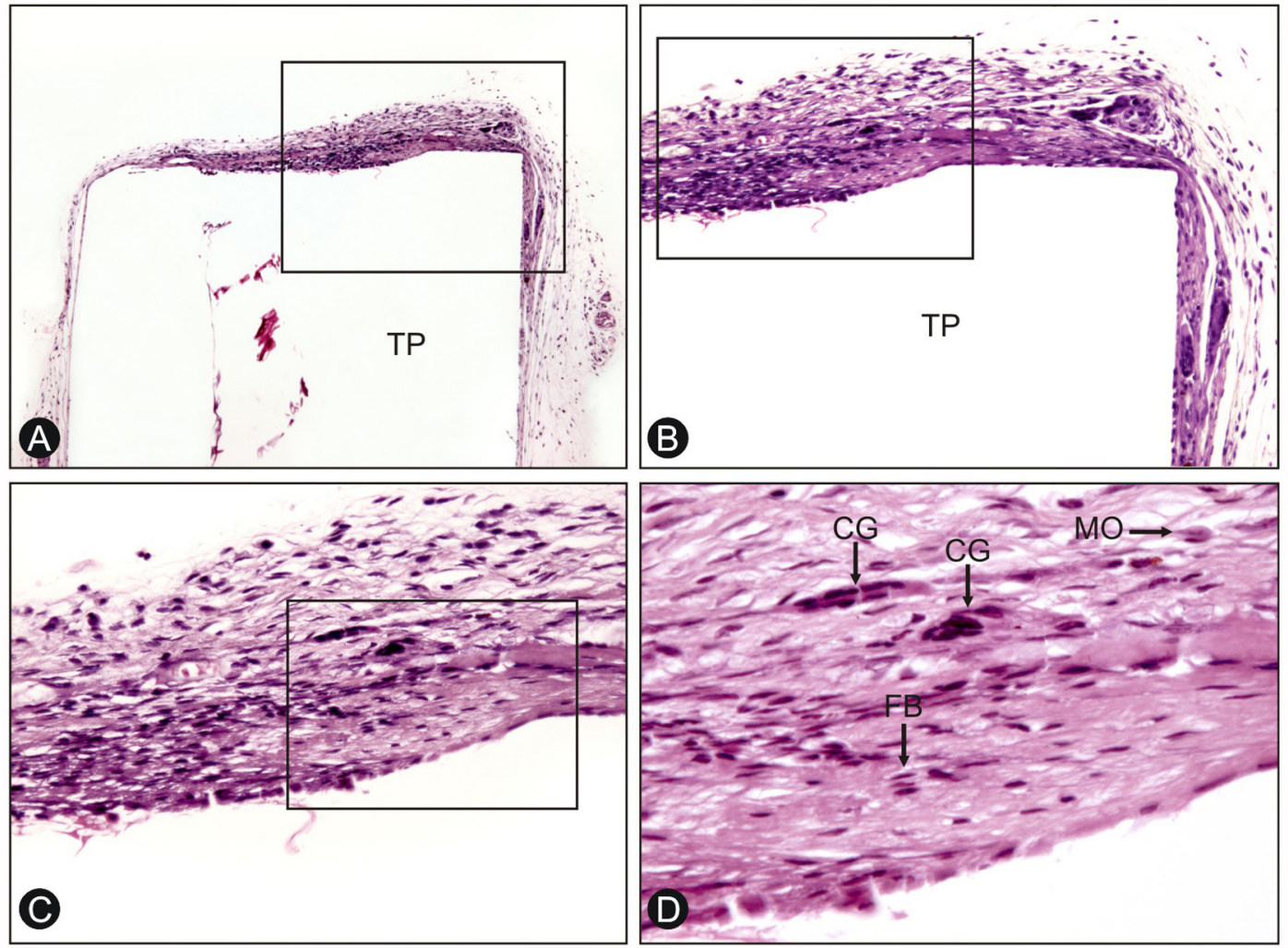


\section{Análise Microscópica Semi - Quantitativa}

A representação gráfica percentual dos escores obtidos após a avaliação do parâmetro fibrosamento nos materiais avaliados, nos diferentes períodos de tempo, pode ser observada na Figura 18.

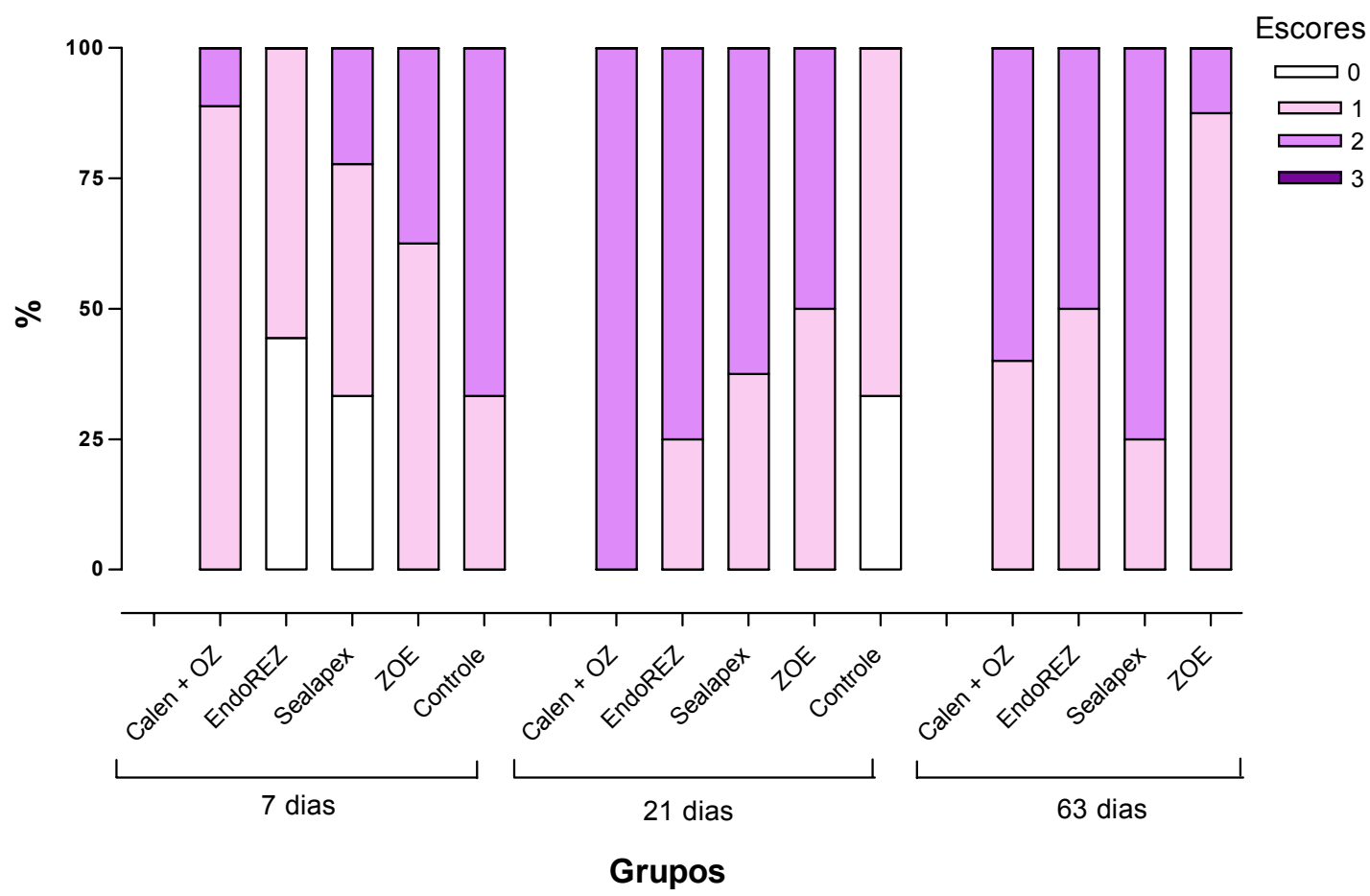

Figura 18 - Porcentagens referentes aos escores atribuídos ao fibrosamento, nos diferentes grupos avaliados.

Em relação ao fibrosamento, no período de 7 dias, o cimento EndoREZ ${ }^{\text {TM }}$ ocasionou a menor quantidade percentual de fibrosamento e o controle a maior. A análise estatística demonstrou diferença significante $(p<0,05)$, apenas entre o cimento EndoREZ ${ }^{\mathrm{TM}}$ e a pasta Calen $^{\circledR}$ espessada com óxido de zinco, entre o cimento EndoREZ ${ }^{\mathrm{TM}}$ e o cimento de óxido de zinco e eugenol, entre o cimento EndoREZ ${ }^{\mathrm{TM}}$ e o controle e entre o cimento Sealapex ${ }^{\circledR}$ e o controle. No período de 21 dias, a maior quantidade percentual de fibrosamento foi verificada frente à pasta Calen ${ }^{\circledR}$ espessada com óxido de zinco, seguida pelo cimento EndoREZ ${ }^{\mathrm{TM}}$ e cimento Sealapex ${ }^{\circledR}$, porém sem diferença estatisticamente significante entre eles $(p>0,05)$. Houve diferença estatisticamente significante entre todos os materiais testados e o controle $(p<0,05)$, e entre a pasta Calen ${ }^{\circledR}$ espessada com óxido de zinco e o cimento de óxido de zinco e eugenol $(p<0,05)$. Aos 63 dias, a análise dos dados não demonstrou diferença estatística entre os diferentes materiais testados $(p>0,05)$. 
A representação gráfica percentual dos escores obtidos após a avaliação do parâmetro infiltrado inflamatório nos materiais avaliados, nos diferentes períodos de tempo, pode ser observada na Figura 19.

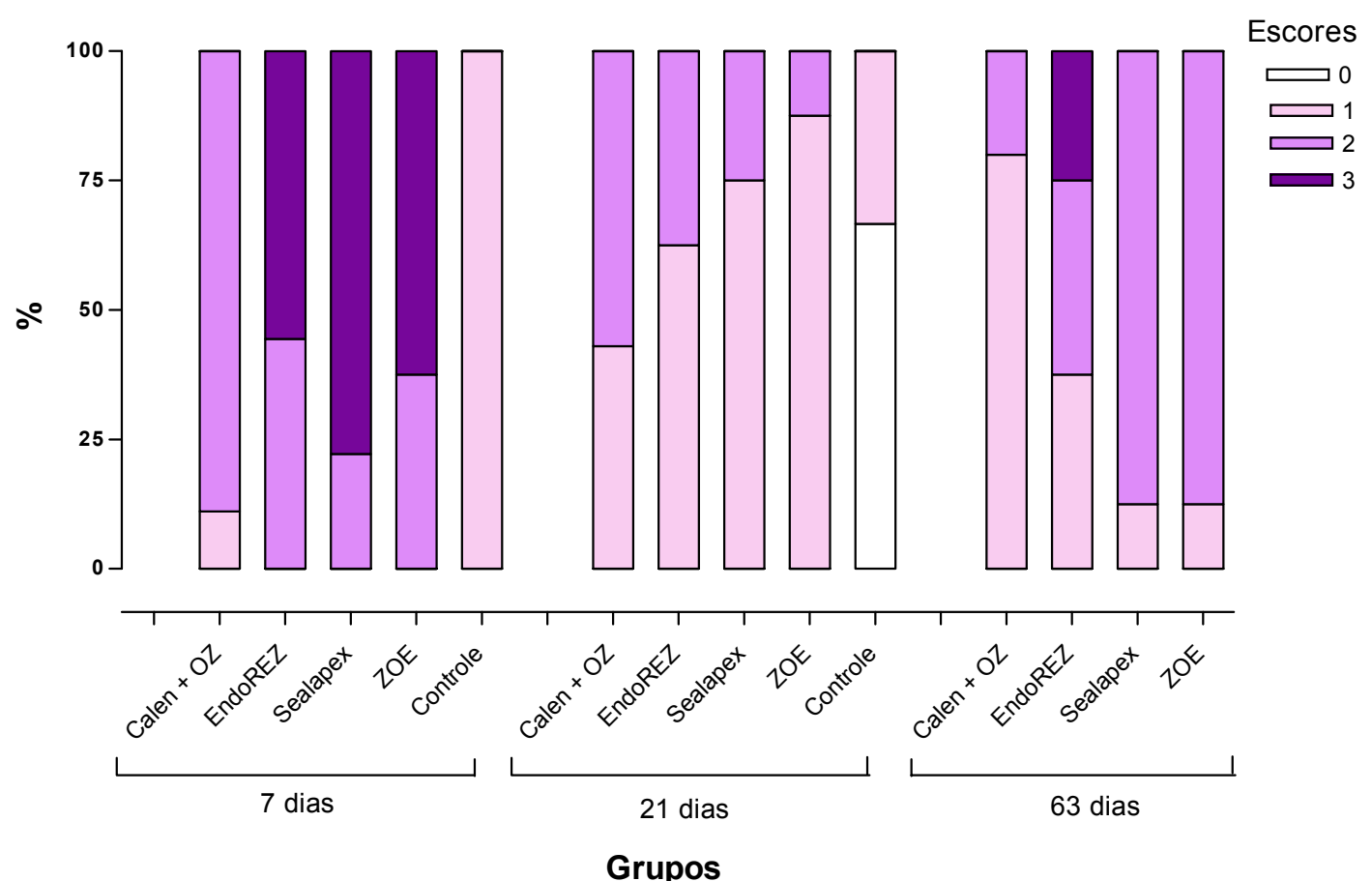

Figura 19 - Porcentagens referentes aos escores atribuídos ao infiltrado inflamatório, nos diferentes grupos avaliados.

Em relação ao infiltrado inflamatório, a análise estatística demonstrou, aos 7 dias, diferença significante entre todos os materiais testados e o controle $(p<0,05)$. Observou-se diferença significante também quando a pasta Calen ${ }^{\circledR}$ espessada com óxido de zinco foi comparada com os cimentos EndoREZ ${ }^{\mathrm{TM}}$, Sealapex ${ }^{\circledR}$, e óxido de zinco e eugenol $(p<0,05)$, ou seja, a pasta Calen ${ }^{\circledR}$ espessada com óxido de zinco gerou um infiltrado inflamatório de menor intensidade que os outros materiais testados. No período de 21 dias, houve diferença estatisticamente significante entre todos os materiais testados e o controle $(p<0,05)$, o qual apresentou ausência de infiltrado inflamatório na maioria dos espécimes. A intensidade do infiltrado inflamatório, quando os diferentes materiais testados foram comparados entre si, não demonstrou diferença estatisticamente significante $(p>0,05)$. Aos 63 dias, houve diferença estatisticamente significante entre a pasta Calen ${ }^{\circledR}$ espessada com óxido de zinco e os outros materiais testados $(p<0,05)$, ou seja, a pasta Calen ${ }^{\circledR}$ espessada com óxido de zinco gerou um infiltrado inflamatório de menor intensidade que o cimento EndoREZ ${ }^{\mathrm{TM}}$, o cimento Sealapex ${ }^{\circledR}$ e o cimento de óxido de zinco e eugenol. 


\section{Análise Microscópica Quantitativa}

A média e o desvio padrão da área do tecido reacional granulomatoso na extremidade-teste nos diferentes grupos pode ser vista na Figura 20 e no Apêndice A.

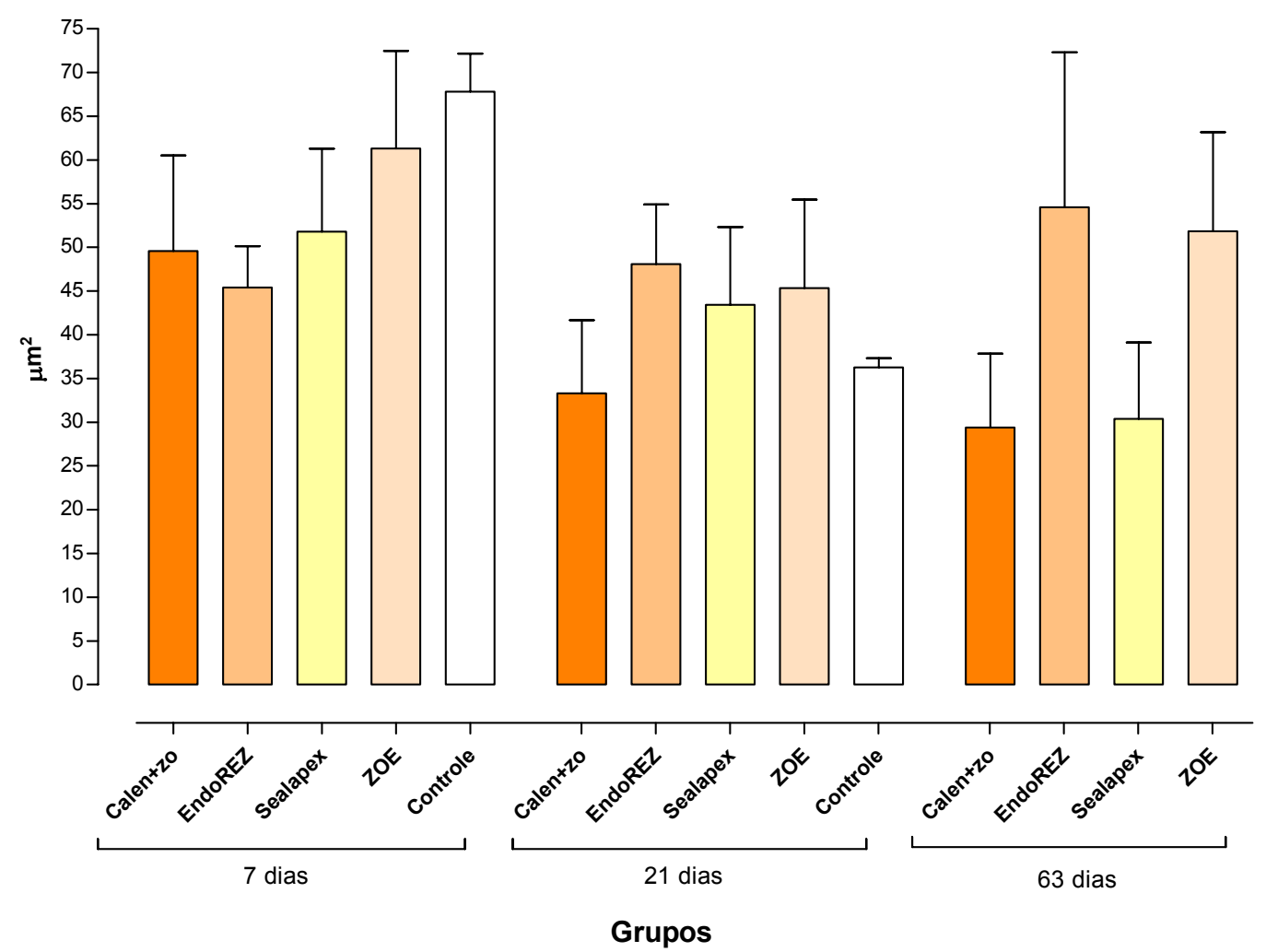

Figura 20 - Média e desvio padrão da área do tecido reacional granulomatoso, nos diferentes grupos avaliados.

Em relação à área do tecido reacional granulomatoso, no período de 7 dias houve diferença estatisticamente significante entre o controle e os seguintes materiais: pasta Calen ${ }^{\circledR}$ espessada com óxido de zinco, cimento EndoREZ ${ }^{\mathrm{TM}}$ e cimento Sealapex $(p<0,05)$ e entre o cimento EndoREZ ${ }^{T M}$ e o cimento de óxido de zinco e eugenol $(p<0,05)$, sendo que o controle apresentou a maior área e o cimento EndoREZ ${ }^{\mathrm{TM}}$ a menor. No período de 21 dias, a área do tecido reacional diminuiu para 0 controle e também para todos os materiais avaliados (exceto para o cimento EndoREZ $\left.{ }^{\mathrm{TM}}\right)$. Houve diferença estatisticamente significante apenas entre a pasta Calen ${ }^{\circledR}$ espessada com óxido de zinco (menor área) e o cimento EndoREZ ${ }^{\mathrm{TM}}(p<0,05)$. Já no período de 63 dias a área diminuiu ainda mais para a pasta Calen ${ }^{\circledR}$ espessada com óxido de zinco e para o cimento Sealapex ${ }^{\circledR}$, e aumentou para os cimentos EndoREZ ${ }^{\mathrm{TM}}$ e óxido de zinco e eugenol. Houve diferença estatisticamente significante 
apenas entre a pasta Calen ${ }^{\circledR}$ espessada com óxido de zinco e os seguintes materiais: cimento EndoREZ ${ }^{\mathrm{TM}}$ e cimento de óxido de zinco e eugenol, e entre o cimento Sealapex ${ }^{\circledR}$ e os seguintes materiais: cimento EndoREZ ${ }^{\mathrm{TM}}$ e cimento de óxido de zinco e eugenol $(p<0,05)$.

A média e o desvio padrão da maior espessura do tecido reacional granulomatoso na extremidade-teste nos diferentes grupos pode ser vista na Figura 21 e no Apêndice $B$.

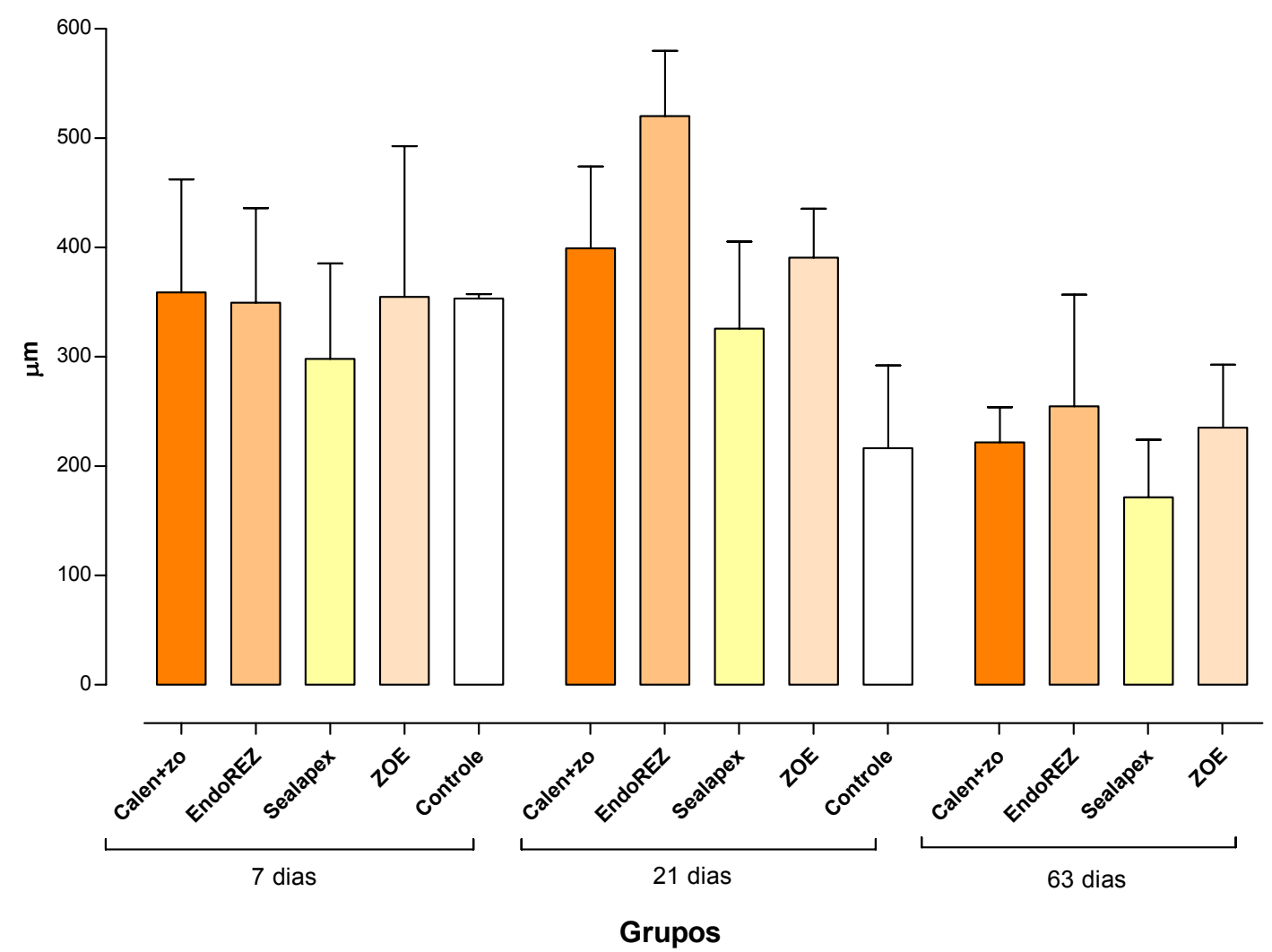

Figura 21 - Média e desvio padrão da maior espessura do tecido reacional granulomatoso, nos diferentes grupos avaliados.

Em relação ao parâmetro maior espessura do tecido reacional granulomatoso, no período de 7 dias a análise estatística não demonstrou diferença significante entre os diferentes grupos $(p>0,05)$. No período de 21 dias, a espessura do tecido reacional frente a todos os materiais testados aumentou, e no grupo controle diminuiu. Foi observada diferença estatisticamente significante quando o cimento EndoREZ $^{\mathrm{TM}}$ (maior espessura) foi comparado com a pasta Calen ${ }^{\circledR}$ espessada com óxido de zinco, com o cimento de óxido de zinco e eugenol, com o cimento Sealapex ${ }^{\circledR}$ e com 
o controle $(p<0,05)$. Houve diferença também entre o cimento de óxido de zinco e eugenol e o controle, e entre a pasta Calen espessada com óxido de zinco e o controle $(p<0,05)$. Já no período de 63 dias, a análise estatística não demonstrou diferença significante entre os diferentes grupos $(p>0,05)$.

A análise geral, dos resultados obtidos, nos permite dizer que a resposta tecidual variou entre os parâmetros avaliados, para os diferentes materiais testados, nos diferentes períodos de tempo. Fibrosamento e espessura foram semelhantes para todos os materiais testados ao final do experimento. A pasta Calen ${ }^{\circledR}$ espessada com óxido de zinco ocasionou uma resposta inflamatória de menor intensidade que os outros materiais tanto ao início, como ao final do experimento. A área do tecido reacional granulomatoso ao final do experimento foi menor para a pasta Calen ${ }^{\circledR}$ espessada com óxido de zinco e para o cimento Sealapex ${ }^{\circledR}$, e semelhantes à do grupo controle. 
Discussão 


\section{Discussão}

\section{1) Atividade Antibacteriana in vitro- Teste de Difusão em Ágar}

Atividade antimicrobiana é uma das propriedades desejadas nos materiais obturadores de canais radiculares (Rifkin, 1980; Tchaou et al., 1995; Tchaou et al., 1996; Leonardo et al., 2000; Mickel et al., 2003; Cobankara et al., 2004; Sipert et al., 2005; Tabrizizadeh e Mohammadi, 2005; Amorim et al., 2006; Bodrumlu e Semiz, 2006; Savioli et al., 2006; Eldeniz et al., 2006; Miyagak et al., 2006; Reddy e Ramakrishna, 2007; Tanomaru-Filho et al. 2007-b), pois mesmo após o preparo biomecânico e a utilização de um curativo de demora, nos dentes com necrose pulpar e lesão periapical, bactérias residuais podem permanecer no sistema de canais radiculares (Sundqvist et al., 1998; Distel et al., 2002; Faria et al., 2005). Portanto, o material obturador deve ser capaz de eliminar microrganismos, neutralizar produtos tóxicos residuais e prevenir a recorrência de infecções no canal radicular, a fim de favorecer o processo de reparo (Leonardo et al., 2000; Leonardo et al., 2007-a).

Com o intuito de se utilizar materiais efetivos na redução/eliminação da infecção bacteriana presente no sistema de canais radiculares de dentes decíduos e permanentes, com necrose pulpar e lesão periapical visível radiograficamente, torna-se necessário avaliar o espectro de ação antimicrobiana dos mesmos. Com essa finalidade, o teste in vitro de difusão em ágar tem sido amplamente empregado (Wright et al., 1994; Tchaou et al., 1996; Leonardo et al., 2000; Gomes et al., 2002; Mickel et al., 2003; Cobankara et al., 2004; Sipert et al., 2005; Tabrizizadeh e Mohammadi, 2005; Amorim et al., 2006; Bodrumlu e Semiz, 2006; Eldeniz et al., 2006; Gomes et al., 2006-b; Miyagak et al., 2006; Reddy e Ramakrishna, 2007; TanomaruFilho et al., 2007-b; Silva, 2007).

O tamanho dos halos de inibição, no teste de difusão em ágar, depende principalmente do tamanho das moléculas e da solubilidade e difusão dos materiais testados (Gomes et al., 2002; Mickel et al., 2003; Cobankara et al., 2004 TanomaruFilho et al., 2007-b). Assim, a extensão da zona de inibição pode não refletir com exatidão a potência da atividade antimicrobiana do material testado (Tanomaru-Filho et al., 2007-b). Além disso, ao extrapolar os resultados obtidos nesses testes in vitro, deve-se ter em mente que, in vivo, a eficácia dos materiais é geralmente reduzida pela capacidade tampão da dentina, que a quantidade de medicação colocada no interior do 
canal radicular é geralmente menor que a usada em estudos in vitro e que a natureza polimicrobiana das infecções endodônticas, sob a forma de biofilme, dificilmente é reproduzida in vitro (Gomes et al., 2006-b).

Assim, quando se avalia a atividade antibacteriana dos materiais obturadores de canais radiculares, é importante que se utilizem diferentes espécies bacterianas, pois além das infecções endodônticas de dentes decíduos apresentarem natureza polimicrobiana (Pazelli et al., 2003; Silva et al., 2006; Ruviére et al., 2007), a sensibilidade a um mesmo material difere entre os diferentes microrganismos (Tobias et al., 1988). No presente estudo avaliou-se a atividade antibacteriana do cimento de óxido de zinco e eugenol, da pasta Calen ${ }^{\circledR}$ associada ao óxido de zinco, do cimento Sealapex ${ }^{\circledR}$ e do cimento EndoREZ ${ }^{\mathrm{TM}}$ sobre os microrganismos Kocuria rhizophila, Enterococcus faecalis, Streptococcus mutans, Escherichia coli e Staphylococcus aureus.

A escolha de microrganismos anaeróbios facultativos e aeróbios ocorreu pois esses interagem com os anaeróbios estritos, causando mudanças nas relações nutricionais e mudanças na tensão de oxigênio, que determinam as inter-relações de sobrevivência microbiana, sendo portanto essencial que se avalie a atividade antibacteriana dos materiais endodônticos sobre esses microrganismos (Leonardo et al., 2000).

A Kocuria rhizophila, por ser amplamente reconhecida como um microrganismo com baixa resistência intrínseca, é utilizada como microrganismo controle, sendo empregada em diversos estudos sobre atividade inibitória de materiais obturadores de canal radicular, por meio do teste de difusão em ágar (Leonardo et al., 2000, Sipert et al , 2005; Savioli et al., 2006; Silva, 2007, Tanomaru-Filho et al., 2007b).

A escolha do Enterococcus faecalis deve-se ao fato que esta é uma das espécies bacterianas mais comumente encontrada em dentes com necrose pulpar e freqüentemente associada com insucessos pós-tratamento endodôntico. Como o Enterococcus faecalis persiste mesmo após o preparo biomecânico, o uso de curativos antimicrobianos e a obturação final, é importante que se utilizem materiais obturadores que apresentem atividade antibacteriana contra esse microrganismo (Sundqvist et al., 1998; Gomes et al., 2006-a; Stuart et al., 2006). Segundo Bystrom et al. (1985), o Enterococcus faecalis apresenta capacidade de sobreviver em ambientes com escassez de nutrientes, de invadir túbulos dentinários e de aderir ao colágeno na presença de soro humano. Por esses motivos, esse microrganismo tem sido empregado em diversos estudos relacionados à atividade antimicrobiana de materiais 
endodônticos (Fuss et al. 1997; Leonardo et al., 2000; Mickel et al., 2003; Cobankara et al., 2004; Sipert et al 2005; Viana et al., 2005; Amorim et al., 2006; Bodrumlu e Semiz, 2006; Eldeniz et al., 2006; Savioli et al., 2006; Reddy e Ramakrishna, 2007; Silva, 2007; Tanomaru-Filho et al., 2007-b).

O Streptococcus mutans foi selecionado por ser o agente etiológico primário da doença cárie (Aas et al., 2008), e estar presente em canais radiculares de dentes decíduos de humanos com necrose pulpar e lesão periapical (Pazelli et al., 2003; Silva et al., 2006). Além disso, esse microrganismo foi empregado em diversos estudos com metodologia semelhante à nossa (Leonardo et al., 2000; Tabrizizadeh e Mohammadi, 2005; Savioli et al., 2006; Reddy e Ramakrishna, 2007).

A escolha da Escherichia coli como microrganismo indicador ocorreu por esta ser uma bactéria facultativa Gram-negativa, avaliada em diversos estudos sobre atividade antibacteriana de materiais endodônticos, em teste de difusão em ágar (Cox et al., 1978; Leonardo et al., 2000; Sipert et al., 2005; Savioli et al., 2006; Reddy e Ramakrishna, 2007; Tanomaru-Filho et al., 2007-b). Os microrganismos gramnegativos, além de possuírem diferentes fatores de virulência e gerarem produtos e sub-produtos tóxicos aos tecidos apicais e periapicais, contêm a endotoxina em sua parede celular. Esse fato é particularmente importante, uma vez que a endotoxina, de natureza lipopolissacarídica (LPS), é liberada durante a multiplicação ou morte bacteriana, exercendo uma série de efeitos biológicos importantes (McGee et al., 1992), que levam à reação inflamatória (Rietschel e Brade, 1992; Silva et al., 2002) e reabsorção óssea na região periapical (Stashenko, 1990; Yamasaki et al., 1992; Nelson-Filho et al., 2002).

O Staphylococcus aureus foi selecionado por ser encontrado em infecções endodônticas (Jacinto et al., 2007), e empregado em diversos estudos que avaliaram a inibição de microrganismos, por materiais endodônticos, em teste de difusão em ágar (Cox et al., 1978; Leonardo et al., 2000; Sipert et al., 2005; Tabrizizadeh e Mohammadi, 2005; Amorim et al., 2006; Savioli et al., 2006; Reddy e Ramakrishna, 2007; Tanomaru-Filho et al., 2007-b). No entanto, de acordo com Tronstad et al. (1987) e Reader et al. (1994), a presença de estafilococos em canais radiculares pode ser resultado de contaminação durante o tratamento endodôntico. 


\section{CIMENTO DE ÓXIDO DE ZINCO E EUGENOL}

Os resultados do presente estudo demonstraram que o cimento de óxido de zinco e eugenol apresentou atividade antibacteriana contra Kocuria rhizophila, Enterococcus faecalis, Streptococcus mutans, Escherichia coli e Staphylococcus aureus, com a formação de halos de inibição de respectivamente 32,67; 9; 11; 23,67 e 18mm de diâmetro, sendo o material que ocasionou os maiores halos de inibição frente aos microrganismos Kocuria rhizophila e Escherichia coli e o menor halo de inibição frente ao Enterococcus faecalis.

Tanomaru-Filho et al. (2007)-b avaliando a atividade antimicrobiana do cimento de óxido de zinco e eugenol pelo teste de difusão em ágar, observaram halos de inibição de 29,5mm para o Micrococcus luteus, de 21,5mm para a Escherichia coli, de $21 \mathrm{~mm}$ para o Staphylococcus aureus e de $16,5 \mathrm{~mm}$ para o Enterococcus faecalis. 0 diâmetro dos halos de inibição frente aos microrganismos testados por Tanomaru-Filho et al. (2007)-b está de acordo com os resultados do presente trabalho, no qual em ordem decrescente também observamos o maior halo para a Kocuria rhizophila (anteriormente denominada de Micrococcus luteus), seguido pela Escherichia coli, Staphylococcus aureus e Enterococcus faecalis.

Em 2005, Tabrizizadeh e Mohammadi, verificaram que os halos de inibição do cimento de óxido de zinco e eugenol foram maiores para o Staphylococcus aureus que para o Streptococcus mutans. Em nosso experimento esse fato também foi observado, tendo em vista que obtivemos halos de inibição de $18 \mathrm{~mm}$ para o Staphylococcus aureus e de $11 \mathrm{~mm}$ para o Streptococcus mutans.

Savioli et al. (2006) avaliaram a atividade antimicrobiana de cada um dos componentes de um cimento obturador de canais radiculares de dentes permanentes à base de óxido de zinco e eugenol, por meio do teste de difusão em ágar, contra diversos microrganismos (Kocuria rhizophila, Enterococcus faecalis, Streptococcus mutans, Streptococcus sobrinus, Streptococcus sanguis, Escherichia coli, Staphylococcus aureus, Pseudomonas aeruginosa e Cândida albicans). O eugenol inibiu Kocuria rhizophila, Enterococcus faecalis, Streptococcus mutans, Streptococcus sobrinus, Streptococcus sanguis, Escherichia coli e Staphylococcus aureus. Portanto, o eugenol foi capaz de inibir microrganismos das mesmas espécies que os por nós avaliados. O óxido de zinco inibiu apenas o Streptococcus sobrinus e a Escherichia coli. Talvez o fato da Escherichia coli ser inibida tanto pelo eugenol como pelo óxido de zinco possa explicar nossos resultados, onde o cimento de óxido de zinco e eugenol foi o material que ocasionou a maior inibição quando o microrganismo indicador foi a 
Escherichia coli (halos de 23,67mm de diâmetro), maior até que a ocasionada pelo digluconato de clorexidina a 1\% (halo de 19,33mm de diâmetro).

A atividade antibacteriana do óxido de zinco (pó) contra a Escherichia coli e o Staphylococcus aureus foi avaliada por Sawai (2003), o qual verificou a presença de atividade antibacteriana contra esses dois microrganismos, sendo entretanto mais efetiva contra o Staphylococcus aureus, sugerindo uma forte afinidade entre esse óxido metálico e as células dessa bactéria. Esse efeito antibacteriano potente do óxido de zinco contra o Staphylococcus aureus também foi observado por Jones et al. (2008).

Leonardo et al. (2000), avaliando em teste de difusão em ágar a atividade antibacteriana do óxido de zinco associado à água, observaram a formação de halos de inibição para todos os microrganismos testados (Kocuria rhizophila, Enterococcus faecalis, Streptococcus mutans, Escherichia coli, Staphylococcus aureus, Staphylococcus epidermidis e Pseudomonas aeruginosa), sendo os halos de inibição para Escherichia coli de $4 \mathrm{~mm}$ e para Staphylococcus aureus de 4,5mm. Em nosso experimento, os halos de inibição foram maiores para a Escherichia coli que para o Staphylococcus aureus. Entretanto, o óxido de zinco foi avaliado associado ao eugenol, o que pode ter alterado esse resultado.

De acordo com Hume (1986), Markowitz et al. (1992), Fuss et al. (1997), Leonardo et al. (2000), Mickel et al. (2003) e Reddy e Ramakrishna (2007) o eugenol é um agente antimicrobiano potente, sendo o principal componente a conferir ao cimento de óxido de zinco e eugenol efeitos antimicrobianos. Em 2003, Walsh et al. avaliaram o mecanismo de ação do eugenol sobre bactérias Gram-positivas e Gramnegativas, verificando o rompimento da membrana celular, levando à perda dos componentes intracelulares.

A efetividade antimicrobiana de vários materiais indicados para tratamento endodôntico de dentes decíduos com relação a 21 microrganismos (anaeróbios e aeróbios, Gram-positivos e Gram-negativos), empregando o teste de difusão em ágar, foi avaliada por Tchaou et al. (1996). Os autores verificaram que o óxido de zinco + eugenol, o óxido de zinco + água e o óxido de zinco + clorexidina inibiram todos os microrganismos testados, porém de maneira menos efetiva que os materiais que continham formocresol ou paramonoclorofenol canforado. Observaram também que os microrganismos Gram-negativos foram inibidos mais efetivamente que os Gram-positivos. Em nosso estudo, assim como no de Tchaou et al. (1996), o cimento de óxido de zinco e eugenol também foi capaz de inibir todos os 
microrganismos testados e os halos de inibição observados para a Escherichia coli (Gram-negativo) foram maiores que para os outros microrganismos.

Amorim et al. (2006) avaliaram, por meio do teste de difusão em ágar, a atividade antimicrobiana de diferentes materiais obturadores de canal radicular de dentes decíduos, incluindo o cimento de óxido de zinco e eugenol, sobre 5 microrganismos (Enterococcus faecalis, Staphylococcus aureus, Pseudomonas aeruginosa, Bacillus subtilis e Candida albicans). Os halos de inibição gerados frente aos microrganismos foram de respectivamente $15 \mathrm{~mm} ; 12 \mathrm{~mm} ; 9 \mathrm{~mm} ; 16 \mathrm{~mm}$ e $12 \mathrm{~mm}$ de diâmetro. O cimento de óxido de zinco e eugenol foi o material que inibiu mais eficazmente o Enterococcus faecalis. Contrariamente, no presente estudo, dentre todos os materiais testados, exceto o Endorez ${ }^{\mathrm{TM}}$ o qual não ocasionou nenhuma inibição, 0 cimento de óxido de zinco e eugenol foi o material que ocasionou os menores halos, quando o microrganismo indicador foi o Enterococcus faecalis ( $9 \mathrm{~mm}$ de diâmetro). De maneira inversa, quando o microrganismo indicador foi o Staphylococcus aureus, o diâmetro dos halos de inibição em nosso estudo foram maiores $(18 \mathrm{~mm})$ que no de Amorim et al. (2006).

Reddy e Ramakrishna (2007) também compararam a atividade antimicrobiana de diferentes materiais obturadores de canal radicular de dentes decíduos (óxido de zinco e eugenol, óxido de zinco e eugenol + formocresol, hidróxido de cálcio + água destilada, óxido de zinco + fenol canforado, hidróxido de cálcio + iodofórmio e vaselina) sobre 23 cepas bacterianas, por meio do teste de difusão em ágar. As maiores zonas de inibição foram ocasionadas pelo óxido de zinco e eugenol + formocresol, seguido pelo óxido de zinco e eugenol, óxido de zinco + fenol canforado e hidróxido de cálcio + água. Entretanto, os autores não indicaram o acréscimo do formocresol ao óxido de zinco e eugenol devido à sua toxicidade. Com respeito especificamente ao óxido de zinco e eugenol, este apresentou efeito inibitório pequeno sobre os microrganismos facultativos/aeróbios Gram-positivos, efeito inibitório médio sobre os facultativos/aeróbios Gram-negativos e os anaeróbios Gram-positivos e efeito inibitório intenso sobre os anaeróbios Gram-negativos. Em nosso estudo, o efeito inibitório do cimento de óxido de zinco e eugenol sobre os microrganismos facultativos Gram-positivos foi pequeno apenas para o Enterococcus faecalis e o Streptococcus mutans, para o Staphylococcus aureus o efeito inibitório foi médio e para a Kocuria rhizophila foi intenso. Já para a Escherichia coli (microrganismo facultativo Gramnegativo) o efeito inibitório foi intenso, e no experimento de Reddy e Ramakrishna (2007) para esse tipo de microrganismo foi médio. Uma possível explicação para as 
diferenças de efeito inibitório, além das diferenças metodológicas, pode ser o fato das cepas bacterianas utilizadas por eles serem oriundas de dentes decíduos infectados de pacientes atendidos pelos mesmos e as nossas de cepas bacterianas estandardizadas (ATTC-American Type Culture Collection).

\section{PASTA CALEN $^{\circledR}$ ESPESSADA COM ÓXIDO DE ZINCO}

A pasta Calen ${ }^{\circledR}$, um produto à base de hidróxido de cálcio associado ao polietilenoglicol, tem sido amplamente utilizada na Odontologia em diversas situações clínicas (Silva, 1988; Nelson-Filho, 1996; Assed, 2005; Leonardo, 2005).

A presença de atividade antibacteriana na pasta Calen ${ }^{\circledR}$ foi comprovada por diversos autores (Assed, 1994; Leonardo et al., 1995; Leonardo et al., 1999; Leonardo et al., 2000; Leonardo, 2005; Faria et al., 2005; Silva, 2007; Soares et al., 2007; Tamonaru-Filho et al., 2007-b). No presente estudo a pasta Calen ${ }^{\circledR}$ apresentou atividade antibacteriana contra Kocuria rhizophila, Enterococcus faecalis, Streptococcus mutans, Escherichia coli e Staphylococcus aureus, com a formação de halos de inibição de respectivamente 20,67; 20; 12,33; 15,5 e 19mm de diâmetro.

Leonardo et al. (2000) testaram a atividade antibacteriana da pasta Calen ${ }^{\circledR}$, pelo teste de difusão em ágar, empregando como microrganismos indicadores Kocuria rhizophila, Enterococcus faecalis, Streptococcus mutans, Escherichia coli, Staphylococcus aureus, Staphylococcus epidermides e Pseudomonas aeruginosa, verificando a presença de atividade antibacteriana contra todos os microrganismos, com formação de halos de inibição de respectivamente $18 ; 11,5 ; 24,7 ; 13 ; 13 ; 14,5$; $10,3 \mathrm{~mm}$, o que está de acordo com nossos resultados.

Tanomaru-Filho et al. (2007)-b avaliaram a atividade antibacteriana, pelo teste de difusão em ágar, da pasta Calen ${ }^{\circledR}$ colocada na extremidade de cones de papel absorvente, frente a Kocuria rhizophila, Escherichia coli, Staphylococcus aureus, Staphylococcus epidermidis e Pseudomonas aeruginosa, observando a formação de halos de inibição de aproximadamente $6 \mathrm{~mm}$ para todos os microrganismos, o que também está de acordo com nossos resultados, onde observamos que a pasta Calen ${ }^{\circledR}$ foi capaz de inibir Kocuria rhizophila, Escherichia coli e Staphylococcus aureus.

$O$ efeito antimicrobiano de diferentes materiais obturadores de canal radicular usados em Odontopediatria (pasta Guedes-Pinto, óxido de zinco e eugenol, hidróxido de cálcio + propilenoglicol, pasta poliantibiótica CTZ e Vitapex) sobre 5 microrganismos (Enterococcus faecalis, Staphylococcus aureus, Pseudomonas aeruginosa, Bacillus subtilis e Candida albicans), utilizando o teste de difusão em ágar, 
foi comparado por Amorim et al. (2006). Todas as pastas induziram a formação de halos de inibição, exceto o Vitapex. A pasta de hidróxido de cálcio p.a. + propilenoglicol ocasionou halos de inibição de $11 \mathrm{~mm}$ de diâmetro para o Enterococcus faecalis e de $9 \mathrm{~mm}$ para o Staphylococcus aureus. No nosso experimento, onde utilizouse o hidróxido de cálcio + polietilenoglicol $\left(\right.$ pasta Calen ${ }^{\circledR}$ ), os halos de inibição para o Enterococcus faecalis foram de $20 \mathrm{~mm}$ de diâmetro e para o Staphylococcus aureus de $19 \mathrm{~mm}$. As diferenças observadas, talvez possam ser explicadas, pelos diferentes veículos empregados e pelos diferentes períodos de pré-incubação, que no nosso experimento foi de 2 horas, favorecendo a difusão iônica no ágar, enquanto no experimento de Amorim et al. (2006), esse tempo foi de apenas 1 hora.

Como já salientado por Leonardo et al. (2000), ao se testar a atividade antimicrobiana de materiais à base de hidróxido de cálcio, por meio do teste de difusão em ágar, deve-se manter o meio de cultura inoculado à temperatura ambiente por 2 horas, a fim de permitir a dissociação e a difusão do hidróxido de cálcio contido nas pastas e cimentos obturadores, o que é denominado de período de pré-difusão. Nos estudos de Leonardo et al. (2000), Tanomaru-Filho et al. (2007)-b e Silva (2007) esse passo técnico foi efetuado, bem como no presente estudo.

A eficácia antimicrobiana da pasta Calen ${ }^{\circledR}$ foi comprovada, também, por meio de estudo clínico, envolvendo canais radiculares de dentes decíduos com necrose pulpar e lesão periapical, por Faria et al. (2005) que observaram, por meio de cultura microbiana, que o curativo de demora com esta pasta apresentou ação antibacteriana, sendo eficaz na eliminação de microrganismos em 62,5\% dos casos.

No entanto, para sua utilização como material obturador de canais radiculares de dentes decíduos, a pasta Calen $^{\circledR}$ necessita ser espessada com óxido de zinco (Silva e Leonardo, 1995; Assed, 2005; Leonardo et al., 2007-b). Embora a pasta Calen $^{\circledR}$ espessada já tenha sido utilizada por vários pesquisadores (Barroso, 2003; Bezerril, 2003; Pazelli et al., 2003; Rabelo, 2003; Faria et al., 2005), sua atividade antimicrobiana ainda não havia sido avaliada. Nesse estudo, a pasta Calen ${ }^{\circledR}$ espessada $^{\circ}$ com óxido de zinco apresentou atividade antibacteriana contra todos os microrganismos testados (Kocuria rhizophila, Enterococcus faecalis, Streptococcus mutans, Escherichia coli e Staphylococcus aureus), com halos de inibição de respectivamente 21,$33 ; 22 ; 12,67 ; 16$ e $17 \mathrm{~mm}$ de diâmetro.

Ao compararmos o diâmetro dos halos de inibição ocasionados pela pasta Calen ${ }^{\circledR}$ espessada com óxido de zinco com os da pasta Calen ${ }^{\circledR}$, verificamos que 
ocorreu um pequeno aumento nesse diâmetro para a pasta Calen ${ }^{\circledR}$ espessada com óxido de zinco, exceto para o Staphylococcus aureus.

Portanto, deduzimos que o acréscimo do óxido de zinco para espessamento da pasta Calen $^{\circledR}$ não interferiu na sua atividade antimicrobina, ocorrendo até mesmo um suave incremento dessa propriedade. Isso talvez possa ser explicado pelo fato do óxido de zinco também apresentar atividade antibacteriana (Sawai, 2003; Jones et al., 2008). Como já observado por Leonardo et al. (2000), 0 óxido de zinco associado à água inibiu o crescimento de vários microrganismos (Kocuria rhizophila, Enterococcus faecalis, Streptococcus mutans, Escherichia coli, Staphylococcus aureus, Staphylococcus epidermidis e Pseudomonas aeruginosa).

O Enterecoccus faecalis é um microrganismo facultativo considerado como um dos mais resistentes às medicações intracanal à base de hidróxido de cálcio (Basrani et al., 2003; Onçag et al., 2006), tolerando pH elevados, variando de 9 a 11 (Gomes et al., 2006-a). Entretanto, no presente estudo a pasta Calen ${ }^{\circledR}$ e a pasta Calen ${ }^{\circledR}$ espessada com óxido de zinco foram os materiais que ocasionaram os maiores halos de inibição frente a esse microrganismo. Talvez isso se deva ao elevado pH da pasta Calen $^{\circledR}$, o qual é de 12,4 (Silva, 1988; Nelson-Filho, 1996; Assed, 2005; Leonardo, 2005).

Estrela et al. (2001) também observaram que o hidróxido de cálcio associado ao polietilenoglicol apresenta atividade antimicrobiana sobre Enterococcus faecalis, tanto no teste de difusão em ágar, como no teste de contato direto. Segundo os autores, ambos os testes foram válidos para estabelecer o espectro antimicrobiano das pastas à base de hidróxido de cálcio.

A atividade antibacteriana de materiais à base de hidróxido de cálcio é dependente de sua ionização, a qual libera íons hidroxila causando um aumento do $\mathrm{pH}$ (Estrela et al., 1995; Silva et al., 1997-b; Leonardo et al., 2000). Um pH acima de 9 inativa, de forma reversível ou irreversível, as enzimas da membrana citoplasmática do microrganismo, resultando em mudanças nos componentes orgânicos e no transporte de nutrientes (Estrela et al., 1995). Esses íons apresentam ainda ação sobre as células bacterianas por meio da destruição de ácidos graxos insaturados ou fosfolipídeos da membrana citoplasmática bacteriana (Podbielski et al., 2000). A atividade antibacteriana também pode ser resultante da reação do hidróxido de cálcio com o dióxido de carbono no canal radicular, e assim, bactérias dependentes de $\mathrm{CO}_{2}$ não conseguiriam sobreviver (Estrela et al., 1995; Kontakiotis et al., 1995). 


\section{CIMENTO SEALAPEX ${ }^{\circledR}$}

Nossos resultados demonstraram que o cimento Sealapex ${ }^{\circledR}$ apresentou atividade antibacteriana contra todos os microrganismos testados (Kocuria rhizophila, Enterococcus faecalis, Streptococcus mutans, Escherichia coli e Staphylococcus aureus), com a formação de halos de inibição de respectivamente 20,$6 ; 13 ; 11 ; 12$ e $20 \mathrm{~mm}$ de diâmetro. Esses resultados estão de acordo com os observados por Leonardo et al. (2000), que testaram a atividade antibacteriana do cimento Sealapex ${ }^{\circledR}$, pelo teste de difusão em ágar, contra Kocuria rhizophila, Enterococcus faecalis, Streptococcus mutans, Escherichia coli, Staphylococcus aureus, Staphylococcus epidermidis e Pseudomonas aeruginosa, verificando a presença de atividade antibacteriana contra todos os microrganismos, com a formação de halos de inibição de respectivamente 15; $13 ; 13 ; 14,7 ; 13,3 ; 18,7 ; 11,7 \mathrm{~mm}$ de diâmetro.

Concordamos com os resultados obtidos por Fuss et al. (1997), Mickel et al. (2003), Cobankara et al. (2004) e Bodrumlu e Semiz (2006), que avaliaram a atividade antibacteriana de cimentos obturadores de canais radiculares, empregando 0 teste de difusão em ágar, com relação especificamente ao Enterococcus faecalis. Em todos os experimentos, o cimento Sealapex ${ }^{\circledR}$ demonstrou atividade antibacteriana contra esse microrganismo.

Em 2005, Sipert et al. observaram, pelo teste de difusão em ágar, que o cimento Sealapex ${ }^{\circledR}$ ocasionou halos de inibição de respectivamente $14 ; 22 ; 15 ; 7,33$; 10,33; 16 e 23,66mm de diâmetro, contra os microrganismos Enterococcus faecalis, Escherichia coli, Micrococcus luteus, Staphylococcus aureus, Staphylococcus epidermidis, Pseudomonas aeruginosa e Candida albicans. Comparando o diâmetro, em milímetros, dos halos de inibição desse estudo com os do nosso observamos diferenças, as quais podem ser explicadas por diferenças do meio de cultura, da procedência dos microrganismos, da estandardização da densidade de inoculação, do contato entre o material testado e as bordas do gel, da atmosfera de incubação e da interpretação das zonas de inibição.

Tanomaru-Filho et al. (2007)-b observaram que quando o cimento Sealapex ${ }^{\circledR}$ foi acrescido de óxido de zinco, com a finalidade de melhorar sua consistência para ser empregado em obturação retrógrada, este continuou apresentando atividade antimicrobiana contra Micrococcus luteus, Enterococcus faecalis, Pseudomonas aeruginosa, Escherichia coli, Staphylococcus aureus e Candida albicans. 
Contrariando os resultados dos estudos anteriores, e também do nosso, Miyagak et al. (2006) não verificaram atividade antimicrobiana no cimento Sealapex ${ }^{\circledR}$ contra os microrganismos Enterococcus faecalis, Staphylococcus aureus e Candida albicans, com o método de difusão em ágar. Provavelmente esse fato ocorreu por não ter sido efetuada a etapa de pré-difusão, que permite a dissociação e a difusão do hidróxido de cálcio contido nas pastas e cimentos obturadores à base dessa substância (Leonardo et al., 2000).

\section{CIMENTO ENDOREZ ${ }^{\text {TM }}$}

$\mathrm{Na}$ literatura específica, poucos autores avaliaram a atividade antimicrobiana do cimento EndoREZ ${ }^{\mathrm{TM}}$. Sipert et al. (2005), por meio do teste de difusão em ágar, observaram que o cimento EndoREZ ${ }^{\mathrm{TM}}$ não apresentou atividade antimicrobiana sobre nenhum dos microrganismos avaliados, ou seja Enterococcus faecalis, Escherichia coli, Micrococcus luteus, Staphylococcus aureus, Staphylococcus epidermidis, Pseudomonas aeruginosa e Candida albicans. Em 2006, Eldeniz et al. também não observaram a presença de atividade antibacteriana no cimento EndoREZ ${ }^{\mathrm{TM}}$, empregando o teste de difusão em ágar sobre nenhum dos microrganismos avaliados (Enterococcus faecalis, Staphylococcus aureus e Pseudomonas aeruginosa). Entretanto, quando esses autores empregaram o teste de contato direto, observaram pequena atividade antibacteriana contra esses microrganismos. A diferença de resultados entre os 2 testes foi atribuída à presença de componentes insolúveis nesse cimento, incapazes de se difundir no ágar.

No presente estudo, empregando-se o teste de difusão em ágar, o cimento EndoREZ ${ }^{\text {TM }}$ apresentou atividade antibacteriana, embora pequena, contra Kocuria rizhophila $(7 \mathrm{~mm})$ e Staphylococcus aureus $(8 \mathrm{~mm})$, diferentemente do estudo de Sipert et al. (2005) e de Eldeniz et al. (2006) que não observaram atividade antibacteriana contra nenhum microrganismo no teste de difusão em ágar, nem mesmo contra Kocuria rizhophila e Staphylococcus aureus.

Assim, com base nas diferenças estatisticamente significantes entre os materiais obturadores de canais radiculares de dentes decíduos avaliados, podemos concluir que, de maneira geral, frente aos microrganismos avaliados, o cimento de óxido de zinco e eugenol foi o material que apresentou a maior atividade antibacteriana, seguido pela pasta Calen $^{\circledR}$ espessada com óxido de zinco e pelo 
cimento Sealapex ${ }^{\circledR}$. O cimento EndoREZ ${ }^{\mathrm{TM}}$ foi dentre os materiais testados o que apresentou a menor atividade antibacteriana.

Entretanto, acho importante ressaltar que essa atividade antibacteriana mais intensa, atribuída ao cimento de óxido de zinco e eugenol, quando comparado à pasta Calen ${ }^{\circledR}$ espessada com óxido de zinco, deveu-se em parte a inibição mais eficaz da Kocuria rizhophila pelo cimento de óxido de zinco e eugenol que pela pasta Calen ${ }^{\circledR}$ espessada com óxido de zinco, com halos de inibição de respectivamente $32,67 \mathrm{~mm}$ e 21,33mm de diâmetro. Contudo, sabe-se que a resistência intrínseca da Kocuria rizhophila é bastante baixa, assim, acredito que frente a esse microrganismo, a presença de uma atividade bacteriana intensa, não seja de todo necessária. A Escherichia coli, foi o outro microrganismo que foi mais eficazmente inibido pelo cimento de óxido de zinco e eugenol que pela pasta Calen ${ }^{\circledR}$ espessada com óxido de zinco, com a formação de halos de inibição de respectivamente $23,67 \mathrm{~mm}$ e $16 \mathrm{~mm}$ de diâmetro, e embora tenha havido diferença estatisticamente significante, os halos de inibição ocasionados pela pasta Calen $^{\circledR}$ espessada com óxido de zinco não foram pequenos frente a esse microrganismo. Porém, quando o microrganismo indicador foi o Enterococcus faecalis, um microrganismo bastante resistente e presente em canais radiculares de dentes decíduos com necrose pulpar e lesão periapical, e freqüentemente encontrado em dentes que necessitam retratamento endodôntico, a atividade antibacteriana da pasta Calen ${ }^{\circledR}$ espessada com óxido de zinco, foi bem maior que a do cimento de óxido de zinco e eugenol, com a formação de halos de inibição de respectivamente 22 e $9 \mathrm{~mm}$ de diâmetro, nesse caso sim, acredito ser de fundamental importância, a presença de uma intensa atividade antibacteriana. Não houve diferença estatisticamente significante entre a atividade antibacteriana do cimento de óxido de zinco e eugenol e da pasta Calen $^{\circledR}$ espessada com óxido de zinco frente a Streptococcus mutans e Staphylococcus aureus. 


\section{2) Compatibilidade Tecidual in vivo - Estudo em Camundongos Isogênicos}

\section{DO MODELO EXPERIMENTAL UTILIZADO}

Os métodos de testes para implantação em tecido subcutâneo são usados para avaliar a reposta biológica do tecido subcutâneo ao material implantado, podendo avaliar efeitos sub-crônicos (curto período, até 12 semanas) ou efeitos crônicos (longo período, além de 12 semanas). O maior período desse experimento durou 63 dias, ou seja, um período inferior a 12 semanas, portanto este foi um experimento que avaliou os efeitos sub-crônicos. Assim, para este teste poderíamos utilizar animais com expectativa de vida menor como camundongos, ratos, porquinhos da índia ou coelhos (ISO 10993-6, 1994). Optamos pelo uso de camundongos pois, além do tamanho do implante ser compatível com o do animal, esse é o animal mais utilizado em pesquisas científicas no mundo, por ser mamífero, se reproduzir rapidamente, apresentar os mesmos sistemas e órgãos dos humanos, serem pequenos, de baixo custo, facilmente alimentados, armazenados e tratados (WillisOwen e Flint, 2006).

Ainda, em virtude do pequeno tamanho do animal, pode-se utilizar um maior número de animais, o que permite que cada animal receba apenas um implante. Isso é interessante pois diminui o tempo operatório, diminuindo o risco cirúrgico e eliminando o risco existente de que, ao implantarmos em um mesmo animal diversos materiais diferentes, a resposta sistêmica a um material possa interferir nos resultados do outro. Por serem pequenos, os animais de um mesmo grupo podem ser mantidos na mesma caixa. De acordo com a (ISO 10993-6, 1994) a região dorsal foi escolhida pois o risco do animal arrancar o implante é menor e esta área não é sujeita a esforços ou atritos.

Os camundongos utilizados nesse estudo foram do tipo isogênico que, por serem animais gerados em laboratório, semelhantes geneticamente, apresentam padrão homogêneo de resposta frente ao mesmo estímulo. Por essa razão, elimina-se o inconveniente de se testar todos os materiais em um mesmo animal, possibilitando que cada animal receba apenas um implante (Nelson-Filho, 1996). 


\section{DOS PERÍODOS DE TEMPO AVALIADOS}

De acordo com a ISO 10993-6 (1994) em testes de implantação de curto período, em tecido conjuntivo subcutâneo de camundongos, os períodos de tempo avaliados devem ser de 7, 21 e 63 dias. Assim, adotamos esses períodos de tempo em nosso estudo. De acordo com Kao et al. (2006), com relação à resposta biológica, se a reação ao material for favorável aos 60 dias, é pouco provável que uma reação inflamatória subseqüente ocorra, a menos que haja a deterioração do material ou sua colonização por bactérias. Portanto, um período de 6 a 8 semanas é suficiente para esse tipo de estudo, em roedores.

\section{DA OPÇÃO POR IMPLANTES EM TECIDO CONJUNTIVO SUCUTÂNEO}

Os implantes em tecido conjuntivo subcutâneo são usados para avaliar a reposta biológica deste tecido frente ao material implantado, ao nível macro e microscópico (ISO 10993-6, 1994), podendo ser utilizados como fonte preliminar de informações com respeito à compatibilidade do material com a atividade biológica dos tecidos ao seu redor (Zmener et al., 1988; Zmener et al., 1990; Bilginer et al., 1997; Costa et al., 2000; Kaplan et al., 2003; Ozbas et al., 2003; Shimizu et al., 2004; Yaltirik et al., 2004; Zmener et al., 2004; Souza et al., 2006; Sumer et al., 2006; Batista et al., 2007; Silva, 2007; Zafalon et al., 2007).

Vários testes podem ser efetuados para se verificar a compatibilidade biológica de um material. Os testes iniciais ou primários são aqueles que dão uma idéia geral da toxicidade do material e incluem os testes de toxicidade sistêmica aguda, os testes de inalação, os testes de mutagenicidade, o teste letal dominante e os testes de citotoxicidade in vitro. Os testes secundários são aqueles que avaliam a toxicidade local, e incluem os testes nos quais os materiais terão uma permanência mais prolongada em contato com os tecidos, in vivo, tais como os testes de sensibilidade e de irritação de membranas e os implantes em tecido conjuntivo subcutâneo e ósseo. Os testes comprobatórios (no caso de se estar avaliando materiais usados em endodontia) são os que avaliam a resposta do tecido pulpar, tecidos apicais e periapicais frente ao material (Stanley, 1992).

Olsson et al. (1981) e Ozbas et al. (2003) afirmaram que o implante de materiais em tecido conjuntivo é um teste secundário adequado para a avaliação da compatibilidade de materiais endodônticos com a atividade biológica dos tecidos ao seu redor, sendo recomendado antes da realização de testes comprobatórios. De acordo 
com esses autores, as reações tóxicas e inflamatórias apresentam as mesmas características em todos os tecidos conjuntivos, não importando onde este se localiza.

A reação tecidual ocasionada pelos materiais odontológicos, por meio testes onde foram realizados implantes em tecido conjuntivo subcutâneo de camundongos, foi avaliada por Bilginer et al. (1997); Shimizu et al. (2004) e Silva (2007).

\section{DA OPÇÃO PELO USO DE TUBOS DE POLIETILENO}

No presente estudo, os materiais implantados no tecido conjuntivo foram acondicionados em tubos de polietileno, como preconizado por diferentes autores (Molloy et al., 1992; Ozbas et al., 2003; Souza et al., 2006; Batista et al., 2007).

A introdução dos materiais experimentais em tubos é amplamente reconhecida como um método válido para o implante de materiais odontológicos, pois simula as condições clínicas dos canais radiculares, ou seja, o contato da abertura apical com o tecido conjuntivo periapical (Ozbas et al., 2003). Além disso, permite a utilização de materiais recém-manipulados (Kolokuris et al., 1996) e o controle da quantidade de material que ficará em contato com os tecidos (Langeland et al., 1969; Kolokuris et al., 1996; Yaltirik et al., 2004). De acordo com Batista et al. (2007), a intensidade da resposta inflamatória, além de estar na dependência do tipo de material e do período de tempo pós-implante, está na dependência da quantidade de material, sendo de maior intensidade onde houver mais material.

De acordo com Torneck (1966) e Ozbas et al. (2003), o polietileno não causa irritação aos tecidos circunjacentes, assim a reação na abertura do tubo é relacionada apenas à toxicidade do material contido em seu lume.

\section{DOS PARÂMETROS DE RESPOSTA TECIDUAL AVALIADOS}

$\mathrm{Na}$ literatura, observa-se que os parâmetros avaliados pelos diferentes autores (Zmener et al., 1988; Zmener et al., 1990; Molloy et al., 1992; Economides et al., 1995; Bilginer et al., 1997; Kaplan et al., 2003; Ozbas et al., 2003; Shimizu et al., 2004; Yaltirik et al., 2004; Zmener, 2004; Souza et al., 2006; Sumer et al., 2006; Batista et al., 2007; Onay et al., 2007; Zafalon et al., 2007) são praticamente os mesmos e incluem tipo e quantidade de células inflamatórias, fibrosamento, área e espessura do tecido reacional, necrose e fenômenos vasculares. Entretanto, existe 
ausência de consenso com relação à forma de se realizar a avaliação da resposta biológica dos tecidos ao material implantado.

Bilginer et al. (1997) avaliaram qualitativamente o grau de inflamação como leve, moderado ou severo, conforme o tipo (leucócitos polimorfonucleares, linfócitos, macrófagos e células plasmáticas) e a quantidade de células inflamatórias; o tipo de inflamação em aguda (predominância de leucócitos polimorfonucleares e poucos linfócitos, macrófagos e células plasmáticas) ou crônica e a presença de cápsula fibrosa.

Ozbas et al. (2003) e Yaltirik et al. (2004) avaliaram quantitativamente o número de células inflamatórias e atribuíram os seguintes escores: 0 - poucas ou nenhuma célula inflamatória e ausência de reação, 1 - mais de 25 células e reação leve, 2 - entre 25 e 125 células e reação moderada, e 3 - mais de 125 células e reação severa. A espessura da cápsula fibrosa foi medida e classificada como fina (menor que 150ųm) ou espessa (maior que 150 um). Calcificação e necrose foram também avaliadas.

Sumer et al. (2006) avaliaram quantitativamente o número de células inflamatórias. A reação inflamatória foi categorizada como leve (nenhuma ou um número igual ou inferior a 25 células inflamatórias), moderada (mais de 25 células inflamatórias) e severa (células inflamatórias em número incontável e existência de células gigantes e tecido granulomatoso). A espessura da cápsula fibrosa foi medida, e a presença de tecido conjuntivo fibroso ao redor do material significava que este havia sido bem tolerado pelos tecidos.

Os critérios de avaliação da Federação Dentária Internacional (1980), os quais são exclusivamente qualitativos, não sendo atribuídos escores, foram utilizados por Kim et al. (2004) e Zafalon et al. (2007) em seus experimentos. A reação tecidual foi avaliada como ausente ou leve, se a espessura da zona reacional fosse igual ou levemente maior que a espessura ao longo das laterais do tubo e com nenhuma ou poucas células inflamatórias. Moderada, se existisse a presença de macrófagos e/ou células plasmáticas. Severa se houvesse um aumento da zona reacional com a presença de macrófagos e células plasmáticas, focos ocasionais de neutrófilos e/ou linfócitos. Avaliaram, ainda, a presença de células gigantes tipo corpo estranho, material disperso, cápsula fibrosa, tecido ósseo neoformado, tecido necrótico e reabsorção óssea.

Já Zmener (2004), realizou uma avaliação qualitativa, onde atribuiu quatro categorias de escores à reação inflamatória. Nenhuma reação: formação de 
cápsula fibrosa e ausência de células inflamatórias. Reação leve: presença de cápsula fibrosa e poucos linfócitos e plasmócitos. Reação moderada: formação de cápsula fibrosa com presença de macrófagos, leucócitos polimorfonucleares, linfócitos e plasmócitos. Reação severa: grandes acúmulos de leucócitos polimorfonucleares, linfócitos, plasmócitos, macrófagos, células gigantes tipo corpo estranho e capilares congestos.

No trabalho de Batista et al. (2007), a reação tecidual e a intensidade de inflamação foram morfologicamente avaliadas pelo tipo de célula presente no infiltrado inflamatório, pela proliferação de fibroblastos e angioblastos, pela presença de cápsula fibrosa envolvendo o implante e pelos fenômenos vasculares. A reação inflamatória foi classificada como ausente, leve, moderada ou severa e foram atribuídos escores de 0 a 3.

Os critérios utilizados tanto a execução, como para a avaliação da reação tecidual no presente estudo, basearam-se naqueles preconizados pela ISO 10993-6 (1994), segundo a qual a extensão da resposta deve ser determinada pelas medidas da distância da interface implante/tecido para áreas não afetadas, ou seja, áreas com características de tecido e vascularização normais. Os parâmetros da resposta biológica avaliados devem ser inflamação, extensão do fibrosamento, degeneração (mudanças morfológicas do tecido), tipo, número e distribuição de células inflamatórias, presença de necrose, presença de debris (sujidade) e granuloma. Shimizu et al. (2004) também basearam a análise das respostas biológicas, em seu estudo, nos parâmetros de avaliação recomendados pela ISO 10993-6 (1994).

Assim, no presente estudo, primeiramente foi avaliada de forma semiquantitativa o fibrosamento e o infiltrado inflamatório no tecido periférico aos materiais testados e nos grupos controle. No fibrosamento levou-se em consideração o número e a densidade de fibras colágenas de permeio às células periféricas localizadas no tecido reacional circunjacente ao material testado, sendo classificado em ausente, discreto, moderado ou intenso. Um fibrosamento discreto significa que o material implantado é pouco agressivo e que o que ocorreu foi uma acomodação dos tecidos ao implante. Um fibrosamento severo ao longo do tempo significa que o material está sendo encarado pelo organismo como algo estranho a ser circunscrito. No infiltrado inflamatório avaliou-se a concentração de polimorfonucleares tipo neutrófilos, de permeio ao tecido reacional ao redor do material. Esta concentração foi classificada em ausência de infiltrado inflamatório, infiltrado inflamatório discreto, moderado ou intenso. A presença de grande número de neutrófilos significa que o processo 
inflamatório se encontra em um estágio inicial, ou que a agressão ocorre de forma repetida, constante ou, ainda, que ocorreu a contaminação por bactérias. Observou-se ainda a ocorrência de extravasamento de material além da abertura do tubo implantado, abscedeção e calcificação distrófica nos tecidos circunjacentes ao material testado.

A seguir, no presente estudo, foi efetuada uma avaliação quantitativa, na qual foi medida a área $\left(\mu \mathrm{m}^{2}\right)$ e a maior espessura $(\mu \mathrm{m})$ do tecido reacional granulomatoso na extremidade-teste nos diferentes grupos experimentais, em cada espécime, de cada grupo, em que esta medida foi possível de ser realizada. A espessura e a área ocupada pelo tecido reacional constituem um parâmetro de avaliação, pois a maior parte do tecido reacional é ocupada por macrófagos e fibroblastos jovens, mas predominantemente pelos macrófagos. Assim, avaliar a espessura e a área ocupada pela reação tecidual implica em avaliar comparativamente se uma reação tem mais ou menos macrófagos que a outra, ou seja, implica em uma metodologia para avaliar quantitativamente os macrófagos. Foi descrita também a reação tecidual observada frente aos materiais testados e aos grupos controle, nos diferentes períodos experimentais, sem especificar cada um dos espécimes, mas sim caracterizando o grupo analisado como um todo.

\section{DOS RESULTADOS RELATIVOS À COMPATIBILIDADE DOS MATERIAIS TESTADOS COM O TECIDO CONJUNTIVO SUBCUTÂNEO DE CAMUNDONGOS ISOGÊNICOS}

\section{PASTA CALEN $^{\circledR}$ ESPESSADA COM ÓXIDO DE ZINCO}

A pasta Calen $^{\circledR}$ apresenta reconhecida compatibilidade tecidual (Silva, 1988; Leonardo et al., 2003; Silva e Leonardo, 1995; Leonardo et al., 1996; Bittencourt e Mallman, 1997; Motta et al., 1997; Holland et al., 1999; Nelson-Filho et al., 1999; Santos et al., 2000; Delgado, 2002; Barroso, 2003; Assed, 2005; Leonardo, 2005; Herrera et al., 2006; Leonardo et al., 2006; Silva, 2007).

Em 1997, Motta et al. observaram compatibilidade tecidual, após o implante de tubos de teflon contendo a pasta Calen ${ }^{\circledR}$, em tecido conjuntivo subcutâneo de ratos. Embora aos 7 dias a resposta inflamatória tenha sido do tipo crônica, com presença de células gigantes multinucleadas inflamatórias, áreas de necrose e presença de cápsula fibrosa ora fina, ora espessa, entre 60 e 90 dias a reação inflamatória foi discreta e a cápsula fibrosa fina. 
Após injeção da pasta Calen $^{\circledR}$ em tecido conjuntivo subcutâneo de camundongos isogênicos, Nelson-Filho et al. (1999) observaram infiltrado inflamatório neutrofílico e congestão vascular de maior intensidade nas primeiras 48 horas. Ao 70 dia o tecido de granulação apresentou-se organizado e no $15^{\circ}$ dia o reparo tecidual foi completo, demonstrando também a compatibilidade tecidual da pasta Calen ${ }^{\circledR}$.

Em tecido conjuntivo subcutâneo de ratos, Delgado (2002) avaliou a compatibilidade da pasta Calen ${ }^{\circledR}$, associada ou não a clorexidina, após a injeção de $0,1 \mathrm{~mL}$ nas patas dos mesmos. Os resultados demonstraram que as pastas Calen ${ }^{\circledR} \mathrm{e}$ Calen ${ }^{\circledR}$ com clorexidina permitiram o reparo tecidual. Resultados semelhantes foram observados por Silva (2007) após implante, em tecido conjuntivo subcutâneo de camundongos isogênicos, de tubos de polietileno contendo a pasta Calen ${ }^{\circledR}$ com clorexidina.

O veículo empregado na pasta Calen ${ }^{\circledR}$ é o polietilenoglicol. A injeção de polietilenoglicol em tecido conjuntivo subcutâneo de camundongos não ocasiona efeitos adversos, podendo ser empregado como base de cimentos obturadores e biomateriais (Kawakami et al., 2004). A reação do tecido conjuntivo subcutâneo de camundongos, após injeção de pasta à base de hidróxido de cálcio e polietilenoglicol foi avaliada por Shimizu et al. (2004). Até os 21 dias foram observadas alterações necróticas e reação tecidual tipo corpo estranho, com presença de células gigantes inflamatórias multinucleadas, macrófagos, fibroblastos e capilares. Com 84 dias foi visto um tecido fibroso e a ausência de células inflamatórias. Os autores concluíram que a pasta à base de hidróxido de cálcio e polietilenoglicol apresentou compatibilidade tecidual. Relataram, ainda, que o polietilenoglicol é gradativamente fagocitado e excretado na urina e fezes, e que o hidróxido de cálcio, ao reagir com os fluídos teciduais, forma um sal de cálcio não solúvel (fosfato de cálcio), incapaz de causar danos aos tecidos, mesmo no caso de não ser fagocitado pelos macrófagos e células gigantes inflamatórias multinucleadas.

Zanoni (1993), após biopulpectomia em dentes de cães e preenchimento dos canais radiculares com pastas à base de hidróxido de cálcio (pasta Calasept, pasta Calen ${ }^{\circledR}$ e pasta de hidróxido de calcio p.a. e água destilada) observou, após os períodos experimentais de 3, 7 e 15 dias, que todas as pastas mostraram-se irritantes aos tecidos apicais e periapicais. Porém, este resultado não significa a ausência de compatibilidade tecidual dessas pastas pois, neste estudo, o período de tempo final foi muito curto e, nos períodos de tempo iniciais, a resposta tecidual é geralmente mais intensa. 
Em diversos experimentos, onde períodos mais longos de tempo foram empregados, Leonardo e colaboradores comprovaram a compatibilidade da pasta Calen ${ }^{\circledR}$ com a atividade biológica dos tecidos apicais e periapicais de dentes de cães. Em 1996, Leonardo et al., após biopulpectomia e curativo com a pasta Calen ${ }^{\circledR}$, verificaram a integridade dos remanescentes do delta apical e dos tecidos periapicais, durante os períodos experimentais de 7, 15 e 30 dias. Leonardo et al. (2003) observaram reparo tecidual com a deposição de tecido mineralizado cementóide e infiltrado inflamatório discreto, após 3 meses de curativo com a pasta Calen ${ }^{\circledR}$, em dentes de cães com rizogênese incompleta e lesão periapical visível radiograficamente. Em 2006, Leonardo et al. compararam o reparo periapical de dentes de cães com lesão periapical, após curativo com a pasta Calen ${ }^{\circledR}$ por 15, 30 e 180 dias, previamente à obturação do canal radicular, com a obturação do canal radicular em sessão única. Quando foi realizado o curativo, houve deposição de tecido mineralizado na região apical e presença de infiltrado inflamatório suave, constituído predominantemente por células mononucleares, o que não foi observado no outro grupo.

A compatibilidade da pasta Calen ${ }^{\circledR}$ também foi comprovada por Holland et al. (1999) após curativo de demora, em dentes de cães com lesão periapical, seguida da obturação com cimento à base de hidróxido de cálcio. Após 6 meses, 0 reparo tecidual completo foi verificado em $50 \%$ dos casos, e sinais de reparação em $46 \%$.

Entretanto, embora a pasta Calen ${ }^{\circledR}$ apresente compatibilidade tecidual, atividade antimicrobiana, estimule a deposição de tecido mineralizado e inative a endotoxina bacteriana (Silva, 1988; Assed, 1994; Leonardo et al., 2003; Leonardo et al., 1995; Silva e Leonardo, 1995; Leonardo et al., 1996; Nelson-Filho, 1996; Bittencourt e Mallman, 1997; Leonardo et al., 1997; Motta et al., 1997; Holland et al., 1999; Leonardo et al., 1999; Nelson-Filho et al., 1999; Leonardo et al., 2000; Santos et al., 2000; Delgado, 2002; Nelson-Filho et al., 2002; Silva et al., 2002; Barroso, 2003; Pazelli et al., 2003; Tanomaru et al., 2003; Assed, 2005; Faria et al., 2005; Leonardo, 2005; Herrera et al., 2006; Leonardo et al., 2006; Silva, 2007), para poder ser utilizada como material obturador de canais radiculares de dentes decíduos, esta precisa ser espessada com óxido de zinco (Silva e Leonardo, 1995; Assed, 2005; Leonardo et al., 2007-b) com o objetivo de reduzir a sua fagocitose, a qual clinicamente deve ocorrer simultaneamente à reabsorção das raízes destes dentes.

A pasta Calen ${ }^{\circledR}$ espessada com óxido de zinco já foi utilizada como material obturador de canais radiculares de dentes decíduos por vários pesquisadores 
(Barroso, 2003; Bezerril, 2003; Pazelli et al., 2003; Rabelo, 2003; Faria et al., 2005). Entretanto, sua compatibilidade com a atividade biológica dos tecidos foi avaliada apenas por Barroso (2003), que analisou a resposta dos tecidos apicais e periapicais de dentes de cães, após biopulpectomia e obturação dos canais radiculares com a pasta Calen $^{\circledR}$ espessada com óxido de zinco, observando ligamento periodontal com espessura normal na maioria dos espécimes, infiltrado inflamatório ausente ou suave, do tipo mononuclear e difusamente espalhado pela região periapical e ausência de reabsorção dos tecidos mineralizados. Os resultados do presente estudo, em camundongos, são concordantes com os de Barroso (2003), em cães, tendo em vista que a compatibilidade da pasta Calen ${ }^{\circledR}$ espessada com óxido de zinco foi observada nos dois modelos experimentais.

Em função da escassez de estudos com relação à compatibilidade da pasta Calen ${ }^{\circledR}$ espessada com óxido de zinco com a atividade biológica dos tecidos, e sabendo que o acréscimo de substâncias a um material, com o objetivo de melhorar suas condições clínicas de uso, podem alterar, em muito, a resposta tecidual após sua utilização, nos propusemos a avaliar a reação do tecido conjuntivo subcutâneo de camundongos isogênicos ao implante de tubos de polietileno preenchidos com essa pasta.

Em nosso estudo, a reação tecidual, aos 7 dias, se caracterizou pela presença moderada de neutrófilos polimorfonucleares e macrófagos. Aos 21 dias, os macrófagos ainda podiam ser vistos em grande número e o número de neutrófilos polimorfonucleares variou entre discreto e moderado. Aos 63 dias, a quantidade de neutrófilos polimorfonucleares foi bastante reduzida. Algumas células gigantes inflamatórias multinucleadas puderam ser vistas aos 7 e 21 dias. Aos 63 dias, o número destas células diminuiu. O fibrosamento, aos 7 dias, foi discreto, porém sem caracterizar uma cápsula bem organizada, aos 21 dias foi moderado e de nítida organização capsular, e aos 63 dias variou entre moderado e discreto, e quando discreto, se assemelhava ao dos tecidos circunjacentes. A área do tecido reacional granulomatoso diminuiu com o decorrer do tempo, sendo aos 7 dias de 49,7um², aos 21 dias de 33,33um² e aos 63 dias de 29,42um², aos 63 dias essa área foi até menor que a do grupo controle, que foi de $36,26 \mathrm{um}^{2}$. A espessura do tecido reacional aos 7 dias foi de 359,1um, aos 21 dias de 399,2um e aos 63 dias de 221,8um, sendo aos 63 dias a mais semelhante à espessura do grupo controle $(216,64 \mathrm{~m})$, entre todos os materiais testados.

Aos 63 dias a análise estatística demonstrou que o infiltrado inflamatório gerado pela pasta Calen ${ }^{\circledR}$ espessada com óxido de zinco foi menor que o dos cimentos 
de óxido de zinco e eugenol, Sealapex ${ }^{\circledR}$ e EndoREZ ${ }^{T M}(p<0,05)$. Houve diferença estatisticamente significante $(p<0,05)$ da área do tecido reacional granulomatoso entre a pasta Calen ${ }^{\circledR}$ espessada com óxido de zinco $\left(29,42 u^{2}{ }^{2}\right)$ e os cimentos de óxido de zinco e eugenol $\left(51,85 u^{2} \mathrm{~m}^{2}\right)$ e EndoREZ ${ }^{\mathrm{TM}}\left(54,59\right.$ um $\left.^{2}\right)$. Com relação aos parâmetros fibrosamento e espessura não houve diferença estatística significante entre os diferentes grupos experimentais ( $p>0,05)$.

Alguns autores atribuem aos íons zinco a capacidade de ocasionar reações inflamatórias crônicas (Meryon e Jakeman, 1985; Economides et al., 1995). Segundo Meryon e Jakeman (1985), esses íons além de serem citotóxicos, interferem no processo inflamatório por reduzirem a capacidade de fagocitose dos macrófagos e interferirem na membrana dos lisossomos. Em nosso experimento, o acréscimo do óxido de zinco à pasta Calen $^{\circledR}$ parece não ter interferido com as propriedades biológicas da mesma, tendo em vista que observamos compatibilidade com a atividade biológica dos tecidos periféricos nesse grupo.

A agressividade inicial da pasta Calen $^{\circledR}$ é resultante de sua alcalinidade, que ao contato com tecidos vivos causa uma área de necrose superficial, porém menos intensa que a do hidróxido de cálcio associado à água destilada. Este fato é devido ao veículo empregado (polietilenoglicol) o qual libera íons $\mathrm{H}^{+}$, que se unem com o grupo hidroxila $\left(\mathrm{OH}^{-}\right)$do hidróxido de cálcio neutralizando a reação, justificando em parte essa compatibilidade tecidual inicial (Nelson Filho et al., 1999). Além disso, a pasta de hidróxido de cálcio e polietilenoglicol apresenta menor percentual inicial de liberação de íons cálcio propiciando, entretanto, uma liberação iônica gradativa e uniforme, quando comparada com o hidróxido de cálcio em veículo aquoso (Estrela, 1996). Em nosso estudo, aos 7 dias, a reação tecidual periférica à pasta Calen ${ }^{\circledR}$ espessada com óxido de zinco, se caracterizou pela presença de tecido eosinofílico na interface do mesmo com o tecido circunjacente, resultante da necrose superficial. Porém, essa faixa era estreita e homogênea, o infiltrado inflamatório era menor que o gerado pelos outros materiais testados $(p<0,05)$ e o fibrosamento também era discreto, significando que o material não foi agressivo.

Zelante et al. (1992) avaliaram a compatibilidade da mistura de hidróxido de cálcio e polietilenoglicol e da mistura de hidróxido de cálcio, polietilenoglicol e óxido de zinco, após implante em tecido conjuntivo subcutâneo de ratos. Os animais foram mortos após 7, 14, 28, 60 e 90 dias. Contrariamente aos nossos resultados, de acordo com esses autores, as pastas foram irritantes ao tecido 
conjuntivo, sendo a atividade macrofágica mais intensa no grupo ao qual foi acrescentado o óxido de zinco.

Especificamente em dentes decíduos, o hidróxido de cálcio tem apresentado bons resultados quando empregado para obturação de canais radiculares (Leonardo, 2005; Assed, 2005). O sucesso clínico e radiográfico, após obturação de canais radiculares de dentes decíduos de humanos, com a associação de óxido de zinco, hidróxido de cálcio e água destilada foi verificada por Chawla et al. (2001). Em 2008, Chawla et al. propuseram um novo material para obturação de canais radiculares de dentes decíduos à base de hidróxido de cálcio, óxido de zinco e solução de fluoreto de sódio a $10 \%$, com sucesso clínico e radiográfico verificado durante 2 anos, e sincronia entre a velocidade de fagocitose do material e da reabsorção radicular.

No entanto, em função da escassez de trabalhos avaliando a compatibilidade tecidual da pasta Calen ${ }^{\circledR}$ espessada com óxido de zinco, torna-se difícil uma discussão direta de nossos resultados. Embora tenhamos utilizado implantes de tubos de polietileno, preenchidos com essa pasta, em tecido conjuntivo subcutâneo de camundongos e Barroso (2003) tenha efetuado, com essa pasta, a obturação de canais radiculares de dentes de cães, como já salientado, os resultados de ambos os experimentos demonstraram a compatibilidade da pasta Calen ${ }^{\circledR}$ espessada com óxido de zinco com a atividade biológica dos tecidos.

Um dado que chamou atenção e merece explicação foi o fato da área do tecido reacional granulomatoso, no grupo controle, aos 7 dias, ser maior $(p<0,05)$ que a área de diversos materiais avaliados (pasta Calen ${ }^{\circledR}$ espessada com óxido de zinco, cimentos Sealapex $^{\circledR}$ e EndoREZ ${ }^{\mathrm{TM}}$ ). A explicação para este acontecimento decorre da característica do organismo não tolerar espaços vazios, e o grupo controle, por nós utilizado, foi um tubo de polietileno vazio, assim a resposta tecidual nos períodos iniciais tende a ocupar uma maior área, pois o organismo preenche parte do lume do tubo vazio com exsudato. Uma maneira de contornar esse inconveniente seria utilizar como controle um tubo vedado em sua extremidade ou as paredes laterais do tubo, mas isto não consta das normas ISO 10993-6, (1994).

$\mathrm{Na}$ análise descritiva dos grupos controle, verifica-se que a resposta tecidual, aos 7 e 21 dias, nas paredes laterais do tubo de polietileno foram mais discretas, apresentando menor espessura e celularidade que na sua abertura, sendo mais semelhantes à de um tecido conjuntivo normal. Aos 21 dias, a área do tecido reacional granulomatoso do grupo controle na abertura do tubo já havia diminuído consideravelmente, se igualando a dos outros grupos experimentais $(p>0,05)$. 


\section{ENDOREZ $^{\text {TM }}$}

O uso do cimento EndoREZ ${ }^{\mathrm{TM}}$ como material obturador de canais radiculares de dentes decíduos não foi previamente relatado na literatura específica. Porém, em 1984, Woods et al. indicaram a utilização de um cimento obturador, também à base de metacrilato, para obturação de canais radiculares de dentes decíduos, após verificarem a compatibilidade deste material com os tecidos apicais e periapicais de dentes decíduos de cães. Assim, baseado nesse estudo prévio, nos propusemos a avaliar a compatibilidade tecidual do cimento EndoREZ ${ }^{\mathrm{TM}}$, para que se adequada, este pudesse ser indicado como um possível material obturador de canais radiculares de dentes decíduos.

Propriedades biológicas do cimento EndoREZ ${ }^{\mathrm{TM}}$, tais como citotoxicidade (Bouillaguet et al., 2004; Eldeniz et al., 2007; Lodiene et al., 2008) e reação tecidual, após implante em tecido conjuntivo subcutâneo de ratos (Zmener, 2004; Zafalon et al., 2007) e em tecido ósseo (Zmener et al., 2005; Sousa et al., 2006), foram pouco investigadas.

Zmener (2004) avaliou a resposta tecidual do tecido conjuntivo subcutâneo de ratos após implante de tubos contendo cimento EndoREZ ${ }^{\mathrm{TM}}$, observando uma reação severa até os 30 dias, caracterizada por tecido granulomatoso contendo leucócitos polimorfonucleares, linfócitos, plasmócitos, macrófagos, células gigantes inflamatórias multinucleadas com material em seu citoplasma, vasos sanguíneos e fibroblastos. Com o decorrer do tempo, a reação inflamatória diminuiu e com 120 dias observou-se um tecido conjuntivo normal, embora em alguns espécimes houvesse um infiltrado inflamatório do tipo crônico, provavelmente devido à solubilização do cimento. Nesses espécimes, as partículas do material foram analisadas e identificadas como sendo de zinco e bário. O zinco, quando em contato com culturas de células de fibroblastos e macrófagos, foi tóxico (Meryon e Jakeman, 1985), e o bário causou reações inflamatórias persistentes quando em contato com os tecidos (Smith et al., 1984). Apesar disso, Zmener (2004) considerou o cimento compatível com o tecido subcutâneo de ratos.

De maneira oposta, Zafalon et al. (2007), após implante de tubos contendo cimento EndoREZ ${ }^{\mathrm{TM}}$ em tecido conjuntivo subcutâneo de ratos, observaram reação inflamatória severa, com a presença de células polimorfonucleares durante todos os períodos experimentais (15, 30, 60, 90 dias) a qual, de acordo com os autores, é indicativa da toxicidade do material. A presença de mastócitos, entre vasos 
sanguíneos hiperêmicos, principalmente nos períodos de 30, 60 e 90 dias, sugeriu uma reação tardia de hipersensibilidade aos componentes do material.

Em nosso estudo, assim como no de Zafalon et al. (2007), observamos a presença de neutrófilos polimorfonucleares em todos os períodos experimentais. Aos 7 dias o número de neutrófilos polimorfonucleares foi elevado, diminuindo aos 21 dias para, a seguir, ocorrer aos 63 dias um aumento considerável do número dessas células, o que pode estar relacionado à dissolução do material e à liberação de elementos químicos agressivos. Kim et al. (2004) e Zafalon et al. (2007) com base nos critérios de avaliação da Federação Dentária Internacional (1980), consideram a presença de reação tecidual severa, em qualquer período experimental, inaceitável. Assim, o cimento EndoREZ ${ }^{\mathrm{TM}}$, em nosso experimento, de acordo com os critérios da Federação Dentária Internacional (1980) seria considerado inaceitável, por ter ocasionado, aos 7 dias, resposta inflamatória severa com grande número de neutrófilos polimorfonucleares. Aos 63 dias, também observamos em diversos espécimes, um infiltrado neutrofílico severo.

Em culturas de células, Bouillaguet et al. (2004) observaram que o cimento EndoREZ ${ }^{\mathrm{TM}}$, além de apresentar riscos significantes de toxicidade quando recentemente manipulado, se tornou mais citotóxico com o aumento do tempo de exposição. Em nosso estudo, embora o modelo experimental empregado tenha sido outro, os resultados observados foram semelhantes, pois a partir dos 21 dias, passamos a observar a presença de fragmentação nuclear, evento este que ocorre quando as células entram em contato com materiais altamente tóxicos.

Em nosso estudo, com respeito ao fibrosamento, este aos 21 dias foi maior e mais organizado que aos 7 dias. Contudo, aos 63 dias não foi uniforme e nem organizado de forma regular. A área do tecido reacional granulomatoso aumentou com o decorrer do tempo, atingindo aos 63 dias 54,59um², sendo a maior entre os materiais testados e apresentando diferença estatisticamente significante com a pasta Calen $^{\circledR}$ espessada com óxido de zinco e com o cimento Sealapex ${ }^{\circledR}(p<0,05)$. Aos 21 dias, a espessura do tecido reacional aumentou em relação aos 7 dias, e aos 63 dias o cimento EndoREZ ${ }^{\mathrm{TM}}$ apresentou a maior espessura entre todos os materiais testados, atingindo 255,0um.

A análise estatística dos resultados nos permitiu afirmar que aos 63 dias o infiltrado inflamatório ocasionado pelo cimento EndoREZ ${ }^{\mathrm{TM}}$ foi da mesma magnitude que o dos cimentos Sealapex ${ }^{\circledR}$ e óxido de zinco e eugenol $(p>0,05)$, e maiores que 0 ocasionado pela pasta Calen $^{\circledR}$ espessada com óxido de zinco $(p<0,05)$. A área do tecido reacional granulomatoso frente ao cimento EndoREZ ${ }^{\mathrm{TM}}$ foi a maior entre os 
materiais testados, havendo diferença estatisticamente significante $(p<0,05)$ entre 0 cimento EndoREZ ${ }^{\text {TM }}$ e os materiais à base de hidróxido de cálcio (pasta Calen ${ }^{\circledR}$ espessada com óxido de zinco e cimento Sealapex ${ }^{\circledR}$ ). Com relação aos parâmetros fibrosamento e espessura não houve diferença estatística significante entre os diferentes materiais $(p>0,05)$.

\section{CIMENTO SEALAPEX ${ }^{\circledR}$}

O Sealapex ${ }^{\circledR}$ é um cimento à base de hidróxido de cálcio utilizado, desde há muito, como material obturador de dentes permanentes por apresentar, entre outras características, reconhecida compatibilidade tecidual (Molloy et al., 1992; Mittal et al., 1995, Leonardo et al., 1997; Silva et al., 1997-a; Berbert et al., 2002; Leonardo et al., 2003; Leonardo, 2005; Masuda et al., 2005), sendo esta uma propriedade importante, pois o material obturador permanece em íntimo contato com os tecidos apicais e periapicais, por longos períodos de tempo (Leonardo et al., 2003).

Entretanto, o cimento Sealapex ${ }^{\circledR}$ foi proposto como material obturador de canais radiculares de dentes decíduos apenas recentemente, tendo sido avaliado em um pequeno número de trabalhos de pesquisa (Nery, 2000; Ozalp et al., 2005; Kielbassa et al., 2007; Sari e Okte, 2008).

Ozalp et al. (2005) avaliaram o sucesso clínico e radiográfico, por 18 meses, após obturação de canais radiculares de dentes decíduos com cimento Sealapex ${ }^{\circledR}$ ou com cimento de óxido de zinco e eugenol. Dos 20 dentes obturados com cimento Sealapex ${ }^{\circledR}$ apenas 2 resultaram em insucesso, enquanto que dos 20 obturados com cimento de óxido de zinco e eugenol nenhum resultou em insucesso clínico e radiográfico. Os autores concluíram que a fagocitose do cimento Sealapex ${ }^{\circledR}$, quando utilizado como material obturador de canais radiculares de dentes decíduos, ocorre antes da reabsorção radicular fisiológica em $10 \%$ dos casos. Sari e Okte (2008) verificaram sucesso clínico e radiográfico após 3 anos, em 92,3\% dos dentes decíduos que tiveram seus canais radiculares obturados com o cimento Sealapex ${ }^{\circledR}$. Nenhum dente apresentou fagocitose total do material e, na ocorrência de extravasamento do cimento, sua fagocitose ocorreu sem a presença de efeitos adversos.

A infiltração marginal apical, após obturação de canais radiculares de molares decíduos, com cimento de óxido de zinco e eugenol, cimento Sealapex ${ }^{\circledR}$ ou cimento Apexit ${ }^{\circledR}$, foi avaliada por Kielbassa et al. (2007). O cimento Sealapex ${ }^{\circledR}$ foi, entre os materiais testados, o que apresentou a menor infiltração, sendo sob esse 
aspecto, segundo os autores, uma alternativa viável para obturação de canais radiculares de dentes decíduos.

Após pulpectomia e obturação dos canais radiculares de dentes decíduos de cães com cimento Sealapex ${ }^{\circledR}$, Nery (2000) verificou a presença de compatibilidade com os tecidos periapicais e evidências de fagocitose do material, durante a ocorrência do processo de rizólise.

No presente estudo, 7 dias após a implantação do cimento Sealapex ${ }^{\circledR}$ no tecido conjuntivo subcutâneo de camundongos isogênicos, notou-se grande número de neutrófilos polimorfonucleares, macrófagos e fibroblastos jovens. Aos 21 dias o número de neutrófilos polimorfonucleares diminuiu e os macrófagos e as células gigantes multinucleadas inflamatórias apresentavam em seu citoplasma partículas do material, enquanto que aos 63 dias os neutrófilos polimorfonucleares estavam presentes em grande número, os macrófagos haviam fagocitado o material em abundância e algumas células gigantes multinucleadas inflamatórias estavam presentes. O fibrosamento foi aumentando com o decorrer do tempo, sendo aos 7 dias ausente ou discreto, aos 21 dias discreto ou moderado, e aos 63 dias predominantemente moderado e bem organizado. A área do tecido reacional granulomatoso diminuiu com o decorrer do tempo, atingindo $30,38 \mathrm{um}^{2}$ aos 63 dias, sendo maior apenas que a da pasta Calen ${ }^{\circledR}$. espessada com óxido de zinco. Aos 21 dias a espessura do tecido reacional havia aumentado e aos 63 dias mostrou-se menor que aos 21 dias, sendo a menor espessura observada entre todos os materiais testados $(171,5$ ųm).

A análise estatística dos resultados demonstrou que, aos 63 dias, 0 infiltrado inflamatório gerado pelo cimento Sealapex ${ }^{\circledR}$ foi da mesma magnitude que 0 dos cimentos EndoREZ ${ }^{T M}$ e óxido de zinco e eugenol $(p>0,05)$ e maior que o gerado pela pasta Calen ${ }^{\circledR}$ espessada com óxido de zinco $(p<0,05)$. A área do tecido reacional granulomatoso frente ao cimento Sealapex ${ }^{\circledR}$ foi pequena e sem diferença estatisticamente significante com a da pasta Calen ${ }^{\circledR}$ espessada com óxido de zinco $(p>0,05)$. Houve, porém, diferença estatisticamente significante entre o cimento Sealapex ${ }^{\circledR}$ e o cimento EndoREZ ${ }^{\mathrm{TM}}$ e entre o cimento Sealapex ${ }^{\circledR}$ e o cimento de óxido de zinco e eugenol $(p<0,05)$. Com relação aos parâmetros fibrosamento e espessura não houve diferença estatística significante entre os diferentes grupos experimentais $(p>0,05)$.

Após implantação de tubos de silicone contendo cimento Sealapex ${ }^{\circledR}$, no tecido conjuntivo subcutâneo de ratos, Zmener et al. (1988) observaram após 7 dias um tecido granulomatoso contendo células gigantes tipo corpo estranho e macrófagos 
com material em seu citoplasma, bem como muitos fibroblastos e vasos sanguíneos. Essa reação aumentou, progressivamente, até os períodos de 30 e 90 dias. Enquanto aos 7 dias a área de reação tecidual ao implante do tubo contendo Sealapex ${ }^{\circledR}$ foi de aproximadamente $0,66 \mathrm{~mm}^{2}$, aos 30 dias foi de $0,82 \mathrm{~mm}^{2}$ e aos 90 dias de $1,23 \mathrm{~mm}^{2}$. Segundo os autores a presença de partículas do material no interior de macrófagos, células gigantes multinucleadas inflamatórias e vasos, em locais distantes da abertura dos tubos, foi devido a alguns componentes do cimento Sealapex ${ }^{\circledR}$, como o dióxido de titânio, o qual pode ser facilmente disperso pelos tecidos adjacentes, causando uma reação tipo corpo estranho intensa.

Em 1990, Zmener et al. repetiram o experimento anterior com um cimento Sealapex ${ }^{\circledR}$ experimental, do qual foi eliminado o dióxido de titânio, e observaram uma reação igual a do experimento de 1988. A análise com microsondas eletrônicas, do tecido granulomatoso, mostrou que mesmo após a eliminação do dióxido de titânio, ainda havia a presença de metais pesados no cimento.

Ao contrário dos experimentos de Zmener et al. (1988 e 1990), em nosso experimento, a área do tecido reacional granulomatoso frente ao implante de tubos de polietileno contendo cimento Sealapex ${ }^{\circledR}$ diminuiu com o decorrer do tempo. Entretanto, assim como Zmener et al. (1988 e 1990) observamos macrófagos e células gigantes multinucleados inflamatórias, distribuídas difusamente no tecido reacional, com partículas do material em seu citoplasma. Ainda, Zmener et al. (1988 e 1990), não fizeram referência à presença de neutrófilos polimorfonucleares os quais, em nosso experimento, estavam presentes em todos os períodos, sendo observado um aumento do número dessas células aos 63 dias, em comparação aos 21 dias. Acreditamos que essa intensificação da resposta neutrofílica esteja relacionada à solubilização do cimento e à liberação de produtos mais agressivos, que exacerbaram a reação inflamatória tecidual.

A reação tecidual 3, 10, 20, 30 e 60 dias após implantação de tubos de polietileno contendo cimento Sealapex ${ }^{\circledR}$, no tecido conjuntivo subcutâneo de ratos, foi avaliada por Molloy et al. (1992). Inicialmente foi observada uma inflamação aguda com poucos leucócitos polimorfonucleares. Aos 10 dias a inflamação diminuiu, observando-se alguns macrófagos com material birrefringente em seu interior e algumas células gigantes inflamatórias multinucleadas. Aos 20 e 30 dias a inflamação sofreu nova redução e verificou-se a formação de uma cápsula fibrosa, com presença, ainda, de algumas células gigantes inflamatórias multinucleadas. Aos 60 dias a cápsula estava bem estabelecida, com ausência de inflamação, e apenas algumas células 
gigantes inflamatórias multinucleadas e macrófagos na abertura do tubo, com material insolúvel em seu interior. O material, segundo os autores, foi bem tolerado pelo tecido. Em nosso estudo, também observamos que, com o decorrer do tempo, o fibrosamento foi se tornando mais definido e que, aos 63 dias, a cápsula fibrosa estava bem organizada, e haviam macrófagos com material birrefringente em seu interior e células gigantes multinucleadas inflamatórias. Entretanto, 0 número de neutrófilos polimorfonucleares foi grande tanto no início do experimento como no final, o que está em desacordo com os resultados de Molloy et al. (1992). Tal diferença pode ser explicada pelo fato de Molloy et al. (1992) terem utilizado como modelo experimental ratos, enquanto que no presente estudo foram utilizados camundongos. A ISO 10993-6 (1994) preconiza que os períodos experimentais, nos testes onde se utilizam ratos, sejam de 7, 32 e 84 dias. Assim, o último período no experimento de Molloy et al. (1992) foi muito precoce (60 dias) e, provavelmente, se tivesse sido mais longo, os resultados relativos ao infiltrado inflamatório neutrofílico seriam diferentes. Em nosso experimento, no período de tempo intermediário, o número de neutrófilos também foi pequeno, porém este aumentou com o decorrer do tempo.

Economides et al. (1995), após implantarem tubos de teflon contendo cimento Sealapex ${ }^{\circledR}$, em tecido conjuntivo subcutâneo de ratos observaram, aos 7, 14 e 21 dias, reação inflamatória de moderada a severa, com grande quantidade de material nos tecidos periféricos e grande número de células gigantes tipo corpo estranho, contendo partículas escuras do material, macrófagos, linfócitos e células plasmáticas. Aos 21 dias, uma substância amorfa eosinofílica, em contato direto com o cimento Sealapex ${ }^{\circledR}$, foi observada. Acreditamos que o período de observação nesse experimento tenha sido curto, tendo em vista que os autores avaliaram apenas a resposta tecidual nos períodos iniciais frente ao implante, a qual geralmente costuma ser mais exacerbada. Em nosso experimento, aos 7 dias, também observamos um número muito grande de neutrófilos polimorfonucleares no infiltrado inflamatório, o que caracterizaria uma reação inflamatória severa. Kim et al. (2004) e Zafalon et al. (2007), com base nos critérios de avaliação da Federação Dentária Internacional (1980), consideram a presença de reação tecidual severa, em qualquer período experimental, inaceitável. Assim, com base nesses critérios, o cimento Sealapex ${ }^{\circledR}$, em nosso experimento, seria considerado inaceitável, por ter ocasionado uma resposta inflamatória severa, com grande número de neutrófilos, aos 7 dias.

A reação tecidual, após implante de tubos de silicone contendo cimento Sealapex ${ }^{\circledR}$ em tecido conjuntivo subcutâneo de ratos, foi avaliada por Kaplan et al. 
(2003). Após 14 dias a reação inflamatória foi pequena, com um infiltrado do tipo crônico e vasos, sem uma cápsula fibrosa bem definida. Acreditamos que, como no experimento de Economides et al. (1995), o período de tempo de observação tenha sido muito curto, avaliando apenas a resposta inicial ao material. A cápsula fibrosa num período de tempo tão curto, não estaria mesmo bem definida. Em nosso experimento, no qual utilizamos camundongos, animal experimental onde as respostas são mais precoces que nos ratos, a cápsula apresentou-se bem definida aos 63 dias.

Após injetarem cimento Sealapex ${ }^{\circledR}$ no tecido conjuntivo subcutâneo de ratos, Mittal et al. (1995) observaram que a reação inflamatória foi moderada após 48 horas, sendo observado nesse período o predomínio de leucócitos polimorfonucleares. Já aos 7, 14 dias e 1 mês a reação inflamatória foi leve. Ainda, aos 7 dias, a reação inflamatória foi se tornando mais localizada e, com 14 dias, os fibroblastos começaram a se organizar de forma mais compacta e os macrófagos foram o tipo de célula predominante. Após 1 mês, foi observada a formação de uma cápsula fibrosa e, aos 3 meses, não havia inflamação e a cápsula estava bem formada. Em nosso experimento, aos 7 dias, a reação inflamatória também foi caracterizada pelo grande número de neutrófilos e o fibrosamento também foi se tornando mais organizado com o decorrer do tempo. Entretanto, ao final do experimento, ainda havia um infiltrado inflamatório com muitos neutrófilos, alguns macrófagos e células gigantes multinucleadas inflamatórias.

A resposta inflamatória do tecido conjuntivo subcutâneo de camundongos BALB/C, aos 2, 4, 8 e 16 dias, frente à injeção de cimento Sealapex ${ }^{\circledR}$ foi avaliada por Silva et al. (1997)-a. A reação inflamatória foi caracterizada por intensa quantidade de neutrófilos nos períodos de 2 e 4 dias e, em alguns casos, ocorreu necrose na porção central da lesão, a qual era circundada por células mononucleares. Aos 8 dias o número de células polimorfonucleadas diminuiu e ocorreu um aumento no número e diferenciação de células mononucleares (macrófagos, monócitos e células epitelióides). Aos 16 dias havia poucos neutrófilos e uma intensa reação granulomatosa, com células gigantes e epitelióides. De acordo com os autores, a alta diferenciação celular frente ao cimento Sealapex ${ }^{\circledR}$ pode ser explicada pela grande liberação de íons cálcio, a qual atua no processo de diferenciação celular e na ativação de macrófagos. Em nosso estudo, nos períodos de tempo iniciais, também observamos intensa neutrofilia. Entretanto, embora o número de neutrófilos tenha diminuído no período de tempo intermediário, esse voltou a aumentar no período final, provavelmente devido à solubilização do material e a liberação de elementos tóxicos nos tecidos periféricos. 


\section{ÓXIDO DE ZINCO E EUGENOL}

Embora existam controversas relativas à compatibilidade dos materiais à base de óxido de zinco e eugenol com a atividade biológica dos tecidos apicais e periapiais, estes continuam sendo empregados para a obturação de canais radiculares de dentes decíduos (Sweet, 1930; Foster, 1936; Hobson, 1970; Gould, 1972; Spedding, 1973; O’Riordan e Coll, 1979; Camp, 1984; Coll et al., 1988; Hasselgren et al., 1988; Payne et al., 1993; Sandrian e Coll, 1993; Coll e Sandrian, 1996; Primosch et al., 1997; Mani et al., 2000; Primosch et al., 2005).

No presente estudo, aos 7 dias, o infiltrado inflamatório foi intenso, caracterizado pela presença de muitos neutrófilos e alguns macrófagos. Aos 21 dias, 0 infiltrado inflamatório neutrofílico foi discreto e havia material no interior do citoplasma dos macrófagos. Aos 63 dias, os neutrófilos encontravam-se em quantidade considerável (infiltrado neutrofílico moderado) e os macrófagos não estavam fagocitando o material. Algumas células gigantes inflamatórias multinucleadas estavam presentes em todos os períodos. O fibrosamento, aos 7 dias, foi discreto e com clara organização capsular, aos 21 dias foi moderado e bem organizado do ponto de vista capsular. Aos 63 dias, o fibrosamento diminuiu, sendo mais discreto que aos 7 dias e bem organizado. A área do tecido reacional granulomatoso foi de $61,3 \mathrm{um}^{2}$ aos 7 dias, de $45,33 u^{2} \mathrm{~m}^{2}$ aos 21 dias, e de 51,85um² aos 63 dias. A espessura do tecido reacional, aos 7 dias, foi de 354,7um, aos 21 dias de 390um e aos 63 dias de 235,2um.

A análise estatística dos resultados aos 63 dias demonstrou que 0 infiltrado inflamatório gerado pelo cimento de óxido de zinco e eugenol foi da mesma magnitude que o dos cimentos Sealapex ${ }^{\circledR}$ e EndoREZ ${ }^{\mathrm{TM}}(p>0,05)$ e maior que o da pasta Calen ${ }^{\circledR}$ espessada com óxido de zinco $(p<0,05)$. Houve diferença estatisticamente significante da área do tecido reacional granulomatoso, que foi maior para o cimento de óxido de zinco e eugenol que para o cimento Sealapex ${ }^{\circledR}$ e para a pasta Calen ${ }^{\circledR}$ espessada com óxido de zinco $(p<0,05)$. Com relação aos parâmetros fibrosamento e espessura não houve diferença estatística significante entre os diferentes grupos experimentais $(p>0,05)$.

$\mathrm{Na}$ literatura, trabalhos que empregaram metodologia semelhante à nossa para testar a compatibilidade do cimento de óxido de zinco e eugenol com a atividade biológica dos tecidos são poucos. Entretanto, diversos trabalhos usaram metodologia semelhante a nossa para avaliar a histocompatibilidade de cimentos obturadores de canais radiculares, de dentes permanentes, que contêm em suas formulações óxido de zinco e eugenol (Economides et al., 1995; Kolokuris et al., 1998; 
Kaplan et al., 2003; Batista et al., 2007; Zafalon et al., 2007). Embora esses cimentos contenham óxido de zinco e eugenol, apresentam em sua composição diversas outras substâncias químicas, as quais influenciam a resposta tecidual. Assim, optamos por discutir apenas os resultados dos experimentos que avaliaram a reação tecidual induzida pelo cimento exclusivamente de óxido de zinco e eugenol implantado em tecido conjuntivo subcutâneo de roedores, ou utilizado como material obturador de canais radiculares de dentes de ratos e cães.

Blackman et al. (1989) implantaram no tecido conjuntivo subcutâneo e no tecido ósseo de 30 ratos, pequenos pedaços de cimento de óxido de zinco e eugenol, após reação de presa. A resposta inflamatória foi leve e caracterizada por linfócitos, e poucas ou nenhuma célula gigante tipo corpo estranho após 14, 30 e 80 dias. A presença de fibrosamento foi maior aos 30 e 80 dias, sendo interpretada como a tentativa do organismo de encapsular o material levemente irritante. Os autores consideraram o material compatível com os tecidos. Entretanto, acreditamos que essa resposta tecidual leve, inclusive nos períodos de tempo iniciais, onde a resposta costuma ser mais intensa, ocorreu pelo fato do material ter sido implantado após sua presa. De acordo com Olsson et al. (1981), o implante de materiais em tecido conjuntivo subcutâneo após a presa pode eliminar a possibilidade de avaliação da transitória, porém alta toxicidade que diversos materiais obturadores de canais radiculares possuem antes de sua presa.

Já Costa et al. (1994) optaram por pela implantação de tubos de polietileno preenchidos com cimento à base de antibióticos (cloranfenicol e tetraciclina) ou com cimento de óxido de zinco e eugenol no tecido conjuntivo subcutâneo dorsal de ratos. Os períodos experimentais avaliados foram 3, 5, 7, 15 e 60 dias. No grupo do cimento de óxido de zinco e eugenol foi observada intensa necrose tecidual por contato e intensa presença de células inflamatórias, predominantemente mononucleares. 0 cimento à base de antibiótico causou menor irritação tecidual aos 3 , 5, 7 e 15 dias. Decorrido esse período, a resposta tecidual foi semelhante para os dois materiais. Em nosso estudo, no período de tempo inicial também observamos a presença de infiltrado inflamatório intenso. Entretanto, houve o predomínio de neutrófilos polimorfonucleares. Possivelmente, no estudo de Costa et al. (1994) tenha faltado um período de tempo intermediário, ao redor dos 30 dias, não havendo a necessidade de tantos períodos iniciais, uma vez que pressupõe-se que a resposta de todos seria a mesma, fato este que pudemos observar nos resultados do próprio experimento. 
Por outro lado, Sumer et al. (2006), após implante em tecido conjuntivo subcutâneo de ratos tubos de polietileno contendo diversos materiais odontológicos, entre eles um cimento de óxido de zinco e eugenol, observaram aos 15, 30 e 60 dias uma resposta inflamatória discreta. Aos 15 dias a cápsula fibrosa apresentou 3,9mm de espessura, aos 30 dias 2,52mm e aos 60 dias 2,79mm. Tubos vazios foram usados como controle e a espessura da cápsula fibrosa foi, aos 15 dias 1,96mm, aos 30 dias $2,16 \mathrm{~mm}$ e aos 60 dias 2,27mm. Em nosso experimento, observamos um infiltrado inflamatório discreto apenas aos 21 dias, sendo de intensidade severa aos 7 dias e moderada aos 63 dias, significando aos 7 dias que o processo inflamatório se encontrava em um estágio inicial e aos 63 dias que a agressão estava acontecendo de forma repetitiva. Uma resposta tecidual severa nos períodos iniciais é previsível, mas não o é nos períodos finais (Yaltirik et al., 2004; Sumer et al., 2006). Entretanto, como já salientado, Kim et al. (2004) e Zafalon et al. (2007), com base nos critérios de avaliação da Federação Dentária Internacional (1980), consideram a presença de reação tecidual severa, em qualquer período experimental, inaceitável. Sendo assim, se nos baseássemos nesse critério de avaliação, o cimento de óxido de zinco e eugenol, em nosso experimento, seria considerado inaceitável, por ter induzido uma resposta inflamatória severa, com grande número de neutrófilos aos 7 dias.

Após biopulpectomia em dentes de ratos e preenchimento dos canais radiculares com cimento de óxido de zinco e eugenol, Erausquin e Muruzábal (1967) evidenciaram a alta toxicidade desse material quando em contato com os tecidos periapicais, observando a presença de um infiltrado inflamatório persistente, necrose de tecido ósseo, cemento e ligamento periodontal e resistência do material à fagicitose, com formação de uma cápsula fibrosa ao seu redor. Em 1982, Hendry et al., após biopulpectomia e obturação dos canais radiculares de dentes decíduos de cães com cimento de óxido de zinco e eugenol, verificaram a ocorrência de infiltrado inflamatório crônico, presença de abscesso, reabsorção óssea, além de menor deposição de tecido cementóide. No presente estudo também observamos a presença de infiltrado inflamatório persistente, com um aumento do número de neutrófilos polimorfonucleares ao final do experimento, além de macrófagos e células gigantes inflamatórias multinucleadas, embora o teste utilizado, para a avaliação da compatibilidade tecidual, tenha sido o implante de tubos de polietileno contendo o cimento de óxido de zinco e eugenol em tecido conjuntivo subcutâneo de camundongos. 
Holland et al. (1977), após biopulpectomia e obturação dos canais radiculares de dentes de cães com cimento de óxido de zinco e eugenol observaram completa necrose do coto pulpar aos 2 e 7 dias, com infiltrado inflamatório neutrofílico. Aos 15, 30, 60 e 120 dias a maioria dos remanescentes pulpares permaneceu vital apenas na porção mais apical. Aos 240 dias, a maior parte dos espécimes apresentaram vitalidade tecidual, com algumas células jovens no terço apical. Aposição de cemento e neoformação óssea foram observadas próximo à região periapical. Porém não houve formação de barreira de tecido mineralizado na região apical e reação inflamatória moderada permaneceu na região de ligamento periodontal. Em nosso experimento, também observamos infiltrado inflamatório intenso aos 7 dias, com a presença de muitos neutrófilos e moderado aos 63 dias, com neutrófilos em quantidades consideráveis.

Em 2003, Barroso realizou a biopulpectomia e a obturação dos canais radiculares de dentes de cães com cimento de óxido de zinco e eugenol, observando na região periapical a presença de células inflamatórias, ligamento periodontal aumentado de forma moderada ou severa na maioria das raízes, presença de edema e reabsorção cementária. Resultados semelhantes foram observados por Hendry et al. (1982), após pulpectomia em dentes decíduos de cães e obturação dos canais radiculares com cimento de óxido de zinco e eugenol.

As reações inflamatórias crônicas associadas a este material têm sido atribuídas aos íons zinco (Meryon e Jakeman, 1985) e ao eugenol (Barkin et al., 1984; Hume, 1984; Hume, 1986; Markowitz et al., 1992). De acordo com Economides et al. (1995), em cimentos à base de óxido de zinco e eugenol, o potencial irritativo pode ser atribuído primariamente ao eugenol e, secundariamente, aos íons zinco. Segundo Meryon e Jakeman (1985) os íons zinco, além de serem citotóxicos, interferem no processo inflamatório por meio da redução da fagocitose dos macrófagos e da interferência na membrana dos lisossomos. Hume (1984) analisou, in vitro, os efeitos do eugenol sobre células da polpa humana e fibroblastos verificando que, quando em altas concentrações, essa substância foi capaz de inibir a respiração e causar a morte celular.

De acordo com Markowitz et al. (1992) o eugenol é um óleo essencial com atividade germicida e capacidade anestésica local. Os cimentos de óxido de zinco e eugenol são constituídos por grãos de óxido de zinco embebidos em uma matriz de eugenolato de zinco e, quando expostos aos fluidos teciduais, ocorre a hidrólise do eugenolato de zinco e a liberação de eugenol e de hidróxido de zinco. Segundo os 
autores, a relação pó/líquido não influencia grandemente na liberação de eugenol, sendo os efeitos do eugenol dependentes da concentração de eugenol livre no tecido. Efeitos antiinflamatórios, com inibição da síntese de prostaglandinas, da atividade nervosa e da quimiotaxia de leucócitos, além de efeito analgésico estão relacionados ao uso do eugenol em baixas concentrações, ou seja, isolado por uma camada de dentina. Em altas concentrações, e quando em contato prolongado ou direto com os tecidos, esta substância pode provocar inibição da respiração e divisão celular e, até mesmo, morte celular com necrose tecidual.

Para Segura et al. (1998) o eugenol altera a capacidade de aderência ao substrato dos macrófagos e, conseqüentemente, o processo de fagocitose e para Chen et al. (2008) altera a função antimicrobiana dos neutrófilos, influenciando a reação inflamatória nos tecidos periapicais. Becker et al. (1983) e Souza et al. (2004) relataram que a liberação de eugenol de misturas à base de óxido de zinco e eugenol é inicialmente alta, diminuindo com o decorrer do tempo. Entretanto, essa diminuição é lenta e pequenas quantidades de eugenol continuam sendo liberadas por até um ano. Segundo Souza et al. (2004), pequenas quantidades de eugenol, liberadas em função das reações entre o material e os fluidos teciduais, podem ser responsáveis pelas respostas inflamatórias prolongadas quando do contato do cimento de óxido de zinco e eugenol com tecidos. Molnar (1967) e Yesilsov et al. (1988) salientaram que o eugenol pode permanecer em sua forma livre por até 10 anos. Sarrami et al. (2002) observaram reações de hipersensibilidade após o uso do cimento de óxido de zinco e eugenol para cimentação protética e restauração provisória.

O cimento de óxido de zinco e eugenol apresenta baixa capacidade de ser fagocitado, permanecendo partículas nos tecidos periapicais, mesmo com a reabsorção radicular fisiológica (Erausquin e Muruzábal, 1967; Allen, 1979; Rifkin, 1980; Hendry et al., 1982; Woods et al., 1984; Spedding, 1985; Yacobi et al., 1991; Kubota et al., 1992; Fuks, 2000; Mani et al., 2000; Casas et al., 2004; Primosch et al., 2005). A presença de cimento nos tecidos periapicais pode alterar o trajeto de erupção do dente sucessor permanente em 20\% dos casos (Yacobi et al. 1991; Coll e Sandrian, 1996; Mortazavi e Mesbahi, 2004).

Portanto, com relação à compatibilidade tecidual, ao final do experimento, não observou-se diferenças entre os materiais, com relação ao fibrosamento e à maior espessura do tecido reacional granulomatoso $(p>0,05)$. A pasta Calen ${ }^{\circledR}$ espessada com óxido de zinco foi o material que apresentou o infiltrado inflamatório de menor intensidade $(p<0,05)$. A área do tecido reacional granulomatoso 
foi menor para a pasta Calen $^{\circledR}$ espessada com óxido de zinco e para o cimento Sealapex ${ }^{\circledR}(p>0,05)$ em comparação aos cimentos EndoREZ ${ }^{\text {TM }}$ e óxido de zinco e eugenol $(p<0,05)$. Pôde-se concluir que a pasta Calen ${ }^{\circledR}$ espessada com óxido de zinco foi o material que apresentou a melhor compatibilidade tecidual, seguido pelos cimentos Sealapex ${ }^{\circledR}$ e de óxido de zinco e eugenol. O cimento EndoREZ ${ }^{\mathrm{TM}}$ apresentou resposta tecidual insatisfatória. 
Conclusões 


\section{Conclusões}

Com base nos resultados obtidos nas metodologias empregadas e considerando as suas inerentes limitações pôde-se concluir que:

1- A atividade antibacteriana, in vitro, em ordem decrescente foi: cimento de óxido de zinco e eugenol, pasta Calen ${ }^{\circledR}$ espessada com óxido de zinco, cimento Sealapex ${ }^{\circledR}$ e cimento EndoREZ ${ }^{\mathrm{TM}}$;

2- A pasta Calen ${ }^{\circledR}$ espessada com óxido de zinco foi o material que apresentou a melhor compatibilidade tecidual, seguido pelos cimentos Sealapex ${ }^{\circledR}$ e de óxido de zinco e eugenol. O cimento EndoREZ ${ }^{\mathrm{TM}}$ apresentou resposta tecidual insatisfatória. 


\section{REFERÊNCIAS*}

Aas JA, Griffen AL, Dardis SR, Lee AM, Olsen I, Dewhirst FE, Leys EJ, Paster BJ. Bacteria of dental caries in primary and permanent teeth in children and young adults. J Clin Microbiol 2008;46:1407-17.

Adanir N, Cobankara FK, Belli S. Sealing properties of different resin-based root canal sealers. J Biomed Mater Res B Appl Biomater 2006;77:1-4.

Allen KR. Endodontic treatment of primary teeth. Aust Dent J 1979;24:347-51.

Alves FB, Vieira Rde S. Effects of eugenol and non-eugenol endodontic fillers on short post retention, in primary anterior teeth: an in vitro study. J Clin Pediatr Dent $2005 ; 29: 211-4$.

American Academy of Pediatric Dentistry Clinical Affairs Committee - Pulp Therapy Subcommittee; American Academy of Pediatric Dentistry Council on Clinical Affairs. Guideline on pulp therapy for primary and young permanent teeth. Pediatr Dent 20052006;27(7 Suppl):130-4.

Amorim LF, Toledo OA, Estrela CR, Decurcio DA, Estrela C. Antimicrobial analysis of different root canal filling pastes used in pediatric dentistry by two experimental methods.

Braz Dent J 2006;17:317-22.

Assed S. Prevalência de microrganismos em canais radiculares de dentes humanos com reação periapical crônica. Efeito do preparo biomecânico e do curativo de demora. Imunofluorescência indireta e cultura. Tese. Ribeirão Preto: Faculdade de OdontologiaUSP, 1994.

Assed S. Odontopediatria: Bases científicas para a prática clínica. São Paulo: Artes Médicas, 2005.

Barkin ME, Boyd J, Cohen S. Acute allergic reaction to eugenol. Oral Surg 1984;57:4412.

Barr ES, Flaitz CM, Hicks MJ. A retrospective radiographic evaluation of primary molar pulpectomies. Pediatr Dent 1991;13:4-9.

Barr ES, Kleier DJ, Barr NV. Use of nickel-titanium rotary files for root canal preparation in primary teeth. Pediatr Dent 1999;21:453-4.

*Normas internas do Programa de Pós-graduação em Odontopediatria da FOR/USP(2003), de acordo com o International Committee of Medical Journal Editors. Uniform Requirements for manuscripts submited to by Medical Journal, 1997. Disponível em <http//www.mja.com.au/public/information/uniform.html>. Acesso em: 16 de junho de 2003, e com a Associação Brasileira de Normas Técnicas - NBR 6023, ago. 2002. 
Barroso DS. Avaliação histopatológica dos tecidos apicais e periapicais de dentes de cães, após biopulpectomia e obturação dos canais radiculares com diferentes materiais utilizados em odontopediatria. Dissertação. Ribeirão Preto: Faculdade de OdontologiaUSP, 2003.

Basrani B, Tjaderhane L, Santos M, Pascon E, Grad H, Lawrence HP, Friedman S. Efficacy of chlorhexidine and calcium hydroxide containing medicaments against Enterococcus faecalis in vitro. Oral Surg Oral Med Oral Pathol Oral Radiol Endod 2003;96:618-24.

Batista RF, Hidalgo MM, Hernandes L, Consolaro A, Velloso TR, Cuman RK,CaparrozAssef SM, Bersani-Amado CA. Microscopic analysis of subcutaneous reactions to endodontic sealer implants in rats. J Biomed Mater Res A 2007;81:171-7.

Bawazir OA, Salama FS. Clinical evaluation of root canal obturation methods in primary teeth. Pediatr Dent 2006;28:39-47.

Bawazir OA, Salama FS. Apical microleakage of primary teeth root canal filling materials.

J Dent Child (Chic) 2007;74:46-51.

Becker RM, Hume WR, Wolinksy LE. Release of eugenol from mixtures of ZOE in vitro. J Pedod 1983;8:71-7.

Benfatti SV. Topografia dos canais radiculares dos molares decíduos. Rev Fac Farm Odont Araçatuba 1966;2:104-6.

Benfatti SV, Andrioni JN. In vitro study of drugs used in endodontic treatment of deciduous teeth. Rev Assoc Paul Cirurg Dent 1969;23:213-8.

Bengtson AL, Guedes-Pinto AC. Avaliação da possibilidade de condutometria em molares decíduos. Rev Assoc Paul Cirurg Dent 1983;37:490-501.

Becker RM, Hume WR, Wolinksy LE. Release of eugenol from mixtures of ZOE in vitro. J Pedod 1983;8:71-7.

Berbert FL, Leonardo MR, Silva LA, Tanomaru Filho M, Bramante CM. Influence of root canal dressings and sealers on repair of apical periodontitis after endodontic treatment. Oral Surg Oral Med Oral Pathol Oral Radiol Endod 2002;93:184-9.

Bezerril DDL. Infiltração marginal apical após o uso de duas técnicas de instrumentação de canais radiculares e obturação com materiais utilizados em odontopediatria: estudo in vitro. Dissertação. Ribeirão Preto: Faculdade de Odontologia-USP, 2003.

Bilginer S, Esener T, Söylemezoğlu F, Tiftik AM. The investigation of biocompatibility and apical microleakage of tricalcium phosphate based root canal sealers. J Endod 1997;23:105-9.

Bittencourt AZ, Mallman J, Rezende EV. Comportamento da polpa após pulpotomia e recobrimento com materiais à base de hidróxido de cálcio e de óxido de zinco e eugenol. Rev Bras Odontol 1997;54:138-42. 
Blackman R, Gross M, Seltzer S. An evaluation of the biocompatibility of a glass ionomer-silver cement in rat connective tissue. J Endod 1989;15:76-9.

Bodrumlu E, Semiz M. Antibacterial activity of a new endodontic sealer against Enterococcus faecalis. J Can Dent Assoc 2006;72:637.

Bollmann, TH, editor. A manual of pharmacology and its applications to therapeutics and toxicology. $8^{\text {a }}$ ed. Philadelphia; 1957, p. 1120-1 apud Pereira DV. Revisão e análise dos resultados observados em ensaios clínico-laboratoriais, em dentes decíduos humanos e/ou de animais de laboratório, submetidos à pulpotomia e tratados com as diversas formas terapêuticas. Dissertação. São Paulo: Faculdade de Odontologia-USP, 1999.

Bonow MLM, Gueded-Pinto AC, Bammann LL. Antimicrobial activity of drugs used in pulp therapy of deciduous teeth. Braz Endod J 1996;1:44-8.

Bouillaguet S, Wataha JC, Lockwood PE, Galgano C, Golay A, Krejci I. Cytotoxicity and sealing properties of four classes of endodontic sealers evaluated by succinic dehydrogenase activity and confocal laser scanning microscopy. Eur J Oral Sci 2004;112:18 2-7.

Bystrom A, Claesson R, Sundqvist G. The antibacterial effect of camphorated paramonochlorophenol, camphorated phenol and calcium hydroxide in the treatment of infected root canals. Endod Dent Traumatol 1985;1:170-5.

Camp JH. Pulp therapy for primary and young permanent teeth. Dent Clin North Am 1984;28:651-68.

Casas MJ, Kenny DJ, Johnston DH, Judd PL, Layug MA. Outcomes of vital primary incisor ferric sulfate pulpotomy and root canal therapy. J Can Dent Assoc 2004;70:348.

Cerqueira DF, Mello-Moura AC, Santos EM, Guedes-Pinto AC. Cytotoxicity, histopathological, microbiological and clinical aspects of an endodontic iodoform-based paste used in pediatric dentistry: a review. J Clin Pediatr Dent 2008;32:105-10.

Chawla HS, Mathur VP, Gauba K, Goyal A. A mixture of $\mathrm{Ca}(\mathrm{OH})^{2}$ paste and $\mathrm{ZnO}$ powder as a root canal filling material for primary teeth: a preliminary study. J Indian Soc Pedod Prev Dent 2001;19:107-9.

Chawla HS, Setia S, Gupta N, Gauba K, Goyal A. Evaluation of a mixture of zinc oxide, calcium hydroxide, and sodium fluoride as a new root canal filling material for primary teeth. J Indian Soc Pedod Prev Dent 2008;26:53-8.

Chedid RR, Guedes-Pinto AC, Araújo VC. Reação da polpa ao tratamento endodôntico de decíduos. Rev Gauch Odontol 1992; 40:25-28.

Chen DC, Lee YY, Yeh PY, Lin JC, Chen YL, Hung SL. Eugenol inhibited the antimicrobial functions of neutrophils. J Endod 2008;34:176-80.

Cobankara FK, Altinöz HC, Ergani O, Kav K, Belli S. In vitro antibacterial activities of root-canal sealers by using two different methods. J Endod 2004;30:57-60. 
Cobankara FK, Orucoglu $H$, Sengun A, Belli S. The quantitative evaluation of apical sealing of four endodontic sealers. J Endod 2006;32:66-8.

Coll JA, Josell S, Nassof S, Shelton P, Richards MA. An evaluation of pulpal therapy in primary incisors. Pediatr Dent 1988;10:179-84.

Coll JA, Sadrian, R. Predicting pulpectomy success and its relationship to exfoliation and succedaneous dentition. Pediatr Dent 1996;18:57-63.

Costa CA, Teixeira HM, do Nascimento AB, Hebling J. Biocompatibility of two current adhesive resins. J Endod 2000;26:512-6.

Costa CAS, Benatti Neto C, Abdalla RE, Gonzaga HFS, Lia RCC. Estudo preliminar da compatibilidade biológica de um cimento à base de antibiótico e óxido de zinco e eugenol quando implantado em tecido subcutâneo de rato. Rev Odontol Univ São Paulo 1994;8:65-70.

Cox ST Jr, Hembree JH Jr, McKnight JP. The bactericidal potential of various endodontic materials for primary teeth. Oral Surg Oral Med Oral Pathol 1978;45:94754.

Cunha CBCS, Barceloss R, Primo LG. Soluções irrigadoras e materiais obturadores utilizados na terapia endodôntica de dentes decíduos. Pesq Bras Odontoped Clin Integr 2005; 5:75-83.

Delgado EMS. Estudo da biocompatibilidade de uma pasta à base de hidróxido de cálcio associado ao gluconato de clorexidina a $0,1 \%$, no tecido conjuntivo subcutâneo da pata de ratos. Dissertação. Araraquara: Faculdade de Odontologia-UNESP, 2002.

Distel JW, Hatton JF, Gillespie MJ. Biofilm formation in medicated root canals. J Endod 2002;28:689-93.

Droter JA. Pulp therapy in primary teeth. J Dent Child 1967;34:507-10.

Economides N, Kotsaki-Kovatsi VP, Poulopoulos A, Kolokuris I, Rozos G, Shore R. Experimental study of the biocompatibility of four root canal sealers and their influence on the zinc and calcium content of several tissues. J Endod 1995;21:122-7.

Eldeniz AU, Erdemir A, Hadimli HH, Belli S, Erganis O. Assessment of antibacterial activity of EndoREZ. Oral Surg Oral Med Oral Pathol Oral Radiol Endod 2006;102:11926.

Eldeniz AU, Mustafa K, Ørstavik D, Dahl JE. Cytotoxicity of new resin-, calcium hydroxide- and silicone-based root canal sealers on fibroblasts derived from human gingiva and L929 cell lines. Int Endod J 2007;40:329-37.

Erausquin J, Muruzábal M. Root canal fillings with zinc oxide-eugenol cement in the rat molar. Oral Surg Oral Med Oral Pathol 1967;24:547-58.

Estrela C. Análise química das pastas de hidróxido de cálcio, frente à liberação de íons cálcio, de íons hidroxila e formação de carbonato de cálcio, na presença de tecido conjuntivo de cão. Tese. São Paulo: Faculdade de Odontologia-USP, 1996. 
Estrela C, Rodrigues de Araújo Estrela C, Bammann LL, Pecora JD. Two methods to evaluate the antimicrobial action of calcium hydroxide paste. J Endod 2001;27:720-3.

Estrela C, Sydney GB, Bammann LL, Felippe Júnior O. Mechanism of action of calcium and hydroxyl ions of calcium hydroxide on tissue and bacteria. Braz Dent J 1995;6:8590.

Faraco Júnior IM, Percinoto C. Avaliação de duas técnicas de pulpectomia em dentes decíduos. Rev Assoc Paul Cir Dent 1998;52:400-4.

Faria G, Nelson-Filho P, Freitas AC, Assed S, Ito IY. Antibacterial effect of root canal preparation and calcium hydroxide paste (Calen) on intracanal dressing in primary teeth with apical periodontitis. J Appl Oral Sci 2005;13:351-5.

Federation Dentaire Internationale. Recommended Standard practices for biological evaluation of dental materials. Int Dent J 1980;30:140-88.

Foster HR. The pulpless deciduous teeth. J Am Dent Assoc 1936;23:2057-65.

Fuchino T. Clinical and histopathological studies of pulpectomy in deciduous teeth. Shikwa Gakuho 1980;80:971-1017.

Fuchino T, Kokubo K, Sugihara A, Yakushiji M, Machida Y. Root canals of the maxillary first primary molar. Shikwa Gakuho 1978;78:1829-36.

Fuks AB. Pulp therapy for the primary and young permanent dentitions. Pediatr Dent 2000;44:571-96.

Fuss Z, Weiss EI, Shalhav M. Antibacterial activity of calcium hydroxide-containing endodontic sealers on Enterococcus faecalis in vitro. Int Endod J 1997;30:397-402.

Garcia-Godoy F. Evaluation of an iodoform paste in root canal therapy for infected primary teeth. J Dent Child 1987;54:30-4.

Gerlach E. Root canal therapeutics in deciduous teeth. Dent Surv 1932;8:68-74.

Godoy VL. Distribuição de bactérias planctônicas, colônias bacterianas e biofilmes microbianos em dentes decíduos com pulpite e/ou necrose pulpar. Tese. Bauru: Faculdade de Odontologia-USP, 1999.

Goerig AC, Camp JH. Root canal treatment in primary teeth: a review. Pediatr Dent 1983;5:33-37.

Gomes AMM, Fonseca L, Guedes-Pinto AC. Avaliação microbiológica do preparo biomecânico e de uma pasta obturadora de canais de dentes decíduos necrosados. Rev Odontopediatr Atual Clin 1997;5:93-101.

Gomes BP, Ferraz CC, Vianna ME, Rosalen PL, Zaia AA, Teixeira FB, Souza-Filho FJ. In vitro antimicrobial activity of calcium hydroxide pastes and their vehicles against selected microorganisms. Braz Dent J 2002;13:155-61. 
Gomes BP, Pinheiro ET, Sousa EL, Jacinto RC, Zaia AA, Ferraz CC, de Souza-Filho FJ. Enterococcus faecalis in dental root canals detected by culture and by polymerase chain reaction analysis. Oral Surg Oral Med Oral Pathol Oral Radiol Endod 2006;102:247-53. a

Gomes BP, Vianna ME, NT Sena, Zaia AA, Ferraz CCR, Souza-Filho FJ. In vitro evaluation of the antimicrobial activity of calcium hydroxide combined with chlorhexidine gel used as intracanal medicament. Oral Surg Oral Med Oral Pathol Oral Radiol Endod 2006;102:544-50. b

Gould JM. Root canal therapy for infected primary molar teeth - preliminary report. J Den Child 1972;39:269-73.

Guedes-Pinto AC. Tratamento endodôntico de dentes decíduos. In: Guedes-Pinto AC, editor. Odontopediatria. 7ed. São Paulo: Ed. Santos, 2003.

Guedes-Pinto AC, Paiva JG, Bozzola JR. Tratamento endodôntico de dentes decíduos com polpa mortificada. Rev Assoc Paul Cirurg Dent 1981;35:240-5.

Gulati N, Chandra S, Aggarwal PK, Jaiswal JN, Singh M. Cytotoxicity of eugenol in sealer containing zinc-oxide. Endod Dent Traumatol;7:181-5.

Hasselgren G, Olsson B, Cvek M. Effects of calcium hydroxide and sodium hypoclorite on the dissolution of necrotic porcine muscle. J Endod 1988;14:125-7.

Hendry JA, Jeansonne BG, Dummett Jr CO, Burrell W. Comparison of calcium hydroxide and zinc oxide and eugenol pulpectomies in primary teeth of dogs. Oral Surg Oral Med Oral Pathol 1982;54:445-51.

Herrera $H$, Herrera $H$, Leonardo MR, de Paula e Silva FW, da Silva LA. Treatment of external inflammatory root resorption after autogenous tooth transplantation: case report. Oral Surg Oral Med Oral Pathol Oral Radiol Endod 2006;102:e51-4.

Hibbard ED, Ireland RL. Morphology of tooth canal of the primary molar teeth. J Dent Child 1957;24:250-7.

Ho YC, Huang FM, Chang YC. Mechanisms of cytotoxicity of eugenol in human osteoblastic cells in vitro. Int Endod J 2006;39:389-93.

Hobson P. Pulp treatment of deciduous teeth. Br Dent J 1970;17:275-82.

Holan G, Fuks AB. A comparison of pulpectomies using ZOE and KRI paste in primary molars: a retrospective study. Pediatr Dent 1993;15:403-7.

Holland R, Otoboni Filho JA, Souza V, Nery MJ, Bernabé PFE, Dezan Jr E. Reparação dos tecidos periapicais com diferentes formulações de $\mathrm{Ca}(\mathrm{OH})_{2}$ - Estudo em cães. Rev Assoc Paul Cir Dent 1999;53:327-31.

Holland R, Souza V, Mello W, Russo M. Healing process of the pulp stump and periapical tissues in dog teeth. II: histopathological findings following root filling with zinc oxide-eugenol. Rev Fac Odontol Araçatuba 1977;6:59-64. 
Hosoya N, Takahashi G, Arai T, Nakamura J. Calcium concentration and pH of the periapical environment after applying calcium hydroxide into root canals in vitro. J Endod 2001;27:343-6.

Huang FM, Tsai $\mathrm{CH}$, Yang SF, Chang YC. Induction of interleukin-6 and interleukin-8 gene expression by root canal sealers in human osteoblastic cells. J Endod 2005;31:679-83.

Huang TH, Ding SJ, Kao CT. Biocompatibility of various formula root filling materials for primary teeth. J Biomed Mater Res B Appl Biomater 2007;80:486-90.

Hume WR. Effect of eugenol on respiration and division in human pulp, mouse fibroblasts, and liver cells in vitro. J Dent Res 1984;63:1262-5.

Hume WR. The pharmacologic and toxicological properties of zinc oxide-eugenol. J Am Dent Assoc 1986; 113:789-791.

International Standard ISO 10993-6. Biological evaluation of medical devices- Part 6: Tests for local effects after implantation. 1994:1-11.

Jacinto RC, Gomes BP, Desai M, Rajendram D, Shah HN. Bacterial examination of endodontic infections by clonal analysis in concert with denaturing high-performance liquid chromatography. Oral Microbiol Immunol 2007;22:403-10.

Johnson MS, Britto LR, Guelmann M. Impact of a biological barrier in pulpectomies of primary molars. Pediatr Dent 2006;28:506-10.

Jones N, Ray B, Ranjit KT, Manna AC. Antibacterial activity of ZnO nanoparticle suspensions on a broad spectrum of microorganisms. FEMS Microbiol Lett. 2008;279:71-6.

Juge H. Resorbable pastes for root canal fillings. Int Dent J 1959;9:461-76.

Kao CT, Tsai $\mathrm{CH}$, Huang $\mathrm{TH}$. Tissue and cell reactions to implanted root-end filling materials. J Mater Sci Mater Med. 2006;17:841-7.

Kaplan AE, Ormaechea MF, Picca M, Canzobre MC, Ubios AM. Rheological properties and biocompatibility of endodontic sealers. Int Endod J. 2003;36:527-32.

Kawakami T, Mizoguchi T, Matsuura S, Shimizu T, Kurihara S, Ito M, Kawai T. Histopathological safety evaluation of polyethylene glycol applied subcutaneouslyin mice. J Int Med Res. 2004;32:66-9.

Kawakami T, Nakamura C, Hasegawa $\mathrm{H}$, Eda S. Fate of ${ }^{45} \mathrm{Ca}$-labeled calcium hydroxide in a root canal filling paste embedded in rat subcutaneous tissues. J Endod $1987 ; 13: 220-3$.

Kielbassa AM, Uchtmann $\mathrm{H}$, Wrbas $\mathrm{KT}$, Bitter $\mathrm{K}$. In vitro study assessing apical leakage of sealer-only backfills in root canals of primary teeth. J Dent 2007;35:607-13.

Kim JS, Baek SH, Bae KS. In vivo study on the biocompatibility of newly developed calcium phosphate-based root canal sealers. J Endod 2004;30:708-11. 
Kolokuris I, Beltes $\mathrm{P}$, Economides N, Vlemmas I. Experimental study of the biocompatibility of a new glass-ionomer root canal sealer (Ketac-Endo). J Endod 1996;22:395-8.

Kolokuris I, Economides $\mathrm{N}$, Beltes $\mathrm{P}$, Vlemmas $\mathrm{I}$. In vivo comparison of the biocompatibility of two root canal sealers implanted into the subcutaneous connective tissue of rats. J Endod 1998;24:82-5.

Kontakiotis E, Nakou M, Georgopoulou M. In vitro study of the indirect action of calcium hydroxide on the anaerobic flora of the root canal. Int Endod J 1995;28:285-9.

Kramer PF, Faraco-Júnior IM, Feldens CA. Estado atual da terapia pulpar nas universidades brasileiras - pulpotomia e pulpectomia em dentes decíduos. J Bras Odontopediatr Odontol Bebê 2000;3:222-30.

Kubota K, Golden BE, Penugonda B. Root canal filling materials for primary teeth: a review of the literature. J Dent Child 1992;8:225-7.

Langeland K, Guttuso J, Langeland LK, Tobon G. Methods in the study of biological responses to endodontic materials. Oral Surg 1969;27:522-42.

Lengheden $\mathrm{A}$, Jansson $\mathrm{L}$. $\mathrm{pH}$ effects on experimental wound healing of human fibroblasts in vitro. Eur J Oral Sci. 1995;103:148-55.

Leonardo MR. Endodontia: tratamento de canais radiculares: princípios técnicos e biológicos. São Paulo: Artes Médicas, 2005.

Leonardo MR, Almeida WA, Ito IY, Silva LAB. Radiographic and microbiologic evaluation of postreatment apical and periapical repair of root canals of dog's teeth with experimentally induced chronic lesion. Oral Surg Oral Med Oral Pathol $1994 ; 78: 232-8$.

Leonardo MR, Almeida WA, Silva LAB, Utrilla LS. Histopathological observations of periapical repair in the teeth with radiolucent areas submitted to two different methods of root canal treatment. J Endod 1995;21:137-41.

Leonardo MR, Barnett F, Debelian GJ, de Pontes Lima RK, Bezerra da Silva LA. Root canal adhesive filling in dogs' teeth with or without coronal restoration: a histopathological evaluation. J Endod. 2007;33:1299-303. a

Leonardo MR, Hernandez ME, Silva LA, Tanomaru-Filho M. Effect of a calcium hydroxide-based root canal dressing on periapical repair in dogs: a histological study. Oral Surg Oral Med Oral Pathol Oral Radiol Endod 2006;102:680-5.

Leonardo MR, Elson-Filho P, Silva, RAB. Recentes Avanços Tecnológicos Aplicados no Tratamento de Canais Radiculares de Dentes Decíduos-Seqüência Clínica. In: Rapahel Baldacci Filho; Mary Caroline Skelton Macedo. (Org.). Atualização Clínica em Odontologia. São Paulo: Artes Médicas, 2007, v. 25, p. 297-318. b

Leonardo MR, Salgado AA, Silva LA, Tanomaru Filho M. Apical and periapical repair of dogs' teeth with periapical lesions after endodontic treatment with different root canal sealers. Pesqui Odontol Bras 2003;17:69-74. 
Leonardo MR, Silva LAB, Leonardo RT, Utrilla LS, Assed S. Histological evaluation of therapy using a calcium hydroxide dressing for teeth with incompletely formed apices and periapical lesions. J Endod 1993;19:348-52.

Leonardo MR, Silva LAB, Nelson-Filho P, Silva RAB, Raffaini MS. Ex vivo evaluation of the accuracy of two electronic apex locators during root canal length determination in primary teeth. Int Endod J. 2008;41:317-21.

Leonardo MR, Silva LAB, Tanomaru Filho M, Bonifácio KC, Ito IY. In vitro evaluation of antimicrobial activity of sealers and pastes used in endodontics. J Endod 2000;26:3914.

Leonardo MR, Silva LAB, Utrilla LS, Assed S, Ether SS. Calcium hydroxide root canal sealers--histopathologic evaluation of apical and periapical repair after endodontic treatment. J Endod 1997;23:428-32.

Leonardo MR, Utrilla LS, Assed A, Silva LAB. Avaliação histopatológica dos tecidos apicais e periapicais de dentes de cães após biopulpectomia e utilização de diferentes curativos de demora. Rev Bras Odontol 1996;53:14-9.

Lewis BB. Formaldehyde in dentistry: a review for the millennium. J Clin Pediatr Dent 1998;22:167-77.

Lodiene G, Morisbak E, Bruzell E, Ørstavik D. Toxicity evaluation of root canal sealers in vitro. Int Endod J 2008;41:72-7.

Lu Y, Liu T, Li X, Li H, Pi G. Histologic evaluation of direct pulp capping with a selfetching adhesive and calcium hydroxide in beagles. Oral Surg Oral Med Oral Pathol Oral Radiol Endod 2006;102:e78-84.

Machida Y. Root canal obturation in deciduous teeth. Nippon Shiba Ishikai Zasshi 1983;36:796-802.

Mani SA, Chawla HS, Tewari A, Goyal A. Evaluation of calcium hydroxide and zinc oxide eugenol as root canal filling materials in primary teeth. J Dent Child 2000;67:142-7.

Markowitz K, Moynihan M, Liu M, Kim S. Biologic properties of eugenol and zinc oxideeugenol. A clinically oriented review. Oral Surg Oral Med Oral Pathol 1992;73:729-37.

Mass E, Zilberman UL. Endodontic treatment of infected primary teeth, using Maisto's paste. J Dent Child 1989;56:117-20.

Masuda YM, Wang X, Hossain M, Unno A, Jayawardena JA, Saito K, Nakamura Y, Matsumoto K. Evaluation of biocompatibility of mineral trioxide aggregate with an improved rabbit ear chamber. J Oral Rehabil 2005;32:145-50.

McGee JOD, Isaacson PG, Wright NA. Oxford textbook of pathlogy. Principles of pathology. Oxford, University Press, 1992.

Meryon S, Jakeman $\mathrm{KJ}$. The effects in vitro of zinc released from dental restorative materials. Int Endod J 1985;18:191-198. 
Michel JA. Estudo histopatológico da reação do subcutâneo de camundongos submetidos à ação da pasta obturadora utilizada na terapia endodôntica de dentes decíduos com polpa mortificada. Dissertação. São Paulo: Faculdade de OdontologiaUSP, 1984.

Mickel AK, Nguyen TH, Chogle S. Antimicrobial activity of endodontic sealers on Enterococcus faecalis. J Endod. 2003;29:257-8.

Mittal M, Chandra S, Chandra S. Comparative tissue toxicity evaluation of four endodontic sealers. J Endod 1995;21:622-4.

Miyagak DC, de Carvalho EM, Robazza CR, Chavasco JK, Levorato GL. In vitro evaluation of the antimicrobial activity of endodontic sealers. Braz Oral Res 2006;20:303-6.

Molloy D, Goldman M, White RR, Kabani S. Comparative tissue tolerance of a new endodontic sealer. Oral Surg Oral Med Oral Pathol 1992;73:490-3.

Molnar EJ. Residual eugenol from zinc oxide-eugenol compounds. J Dent Res 1967;46:645-9.

Mortazavi M, Mesbahi M. Comparison of zinc oxide and eugenol, and Vitapex for root canal treatment of necrotic primary teeth. Int J Paediatr Dent 2004;14:417-24.

Motta AG, Apfel MIR, Motta Júnior AG. Reação do tecido conjuntivo subcutâneo de implantes contendo Apexit, Calen e L\&C. Rev Bras Odontol 1997; 54:29-33.

Murata SS. Análise histomorfológica de dentes decíduos de cães após biopulpectomia e obturação dos canais com diferentes materiais. Dissertação. Araçatuba: Univ. Estadual Paulista Júlio de Mesquita Filho;2002.

Murray PE, García Godoy C, García Godoy F. How is the biocompatibility of dental biomaterials evaluated? Med Oral Patol Oral Cir Bucal 2007;12:E258-66.

Nelson-Filho P. Avaliação da resposta inflamatória, após injeção de diferentes pastas à base de hidróxido de cálcio, no tecido conjuntivo subcutâneo e na cavidade peritoneal de camundongos isogênicos. Dissertação. Araraquara: Faculdade de OdontologiaUNESP, 1996.

Nelson-Filho P, Leonardo MR, Silva LA, Assed S. Radiographic evaluation of the effect of endotoxin (LPS) plus calcium hydroxide on apical and periapical tissues of dogs. J Endod 2002;28:694-6.

Nelson-Filho P, Silva LAB, Leonardo MR, Utrilla LS, Figueiredo F. Connective tissue response to calcium hydroxide - based root canal medicaments. Int Endodon J 1999;32:303-11.

Nery RS. Comportamento dos tecidos apicais e periapicais de dentes decíduos de cães após biopulpectomia e obturação dos canais com diferentes cimentos obturadores. Tese. Araçatuba: Faculdade de Odontologia-UNESP, 2000. 
Nurko C, Ranly DM, García-Godoy F, Lakshmyya KN. Resorption of a calcium hydroxide/iodoform paste (Vitapex) in root canal therapy for primary teeth: a case report. Pediatr Dent 2000;22:517-20.

Oliveira LB, Marcenes W, Ardenghi TM, Sheiham A, Bönecker M. Traumatic dental injuries and associated factors among Brazilian preschool children. Dent Traumatol 2007;23:76-81.

Oliveira LD, Leão MV, Carvalho CA, Camargo CH, Valera MC, Jorge AO, Unterkircher CS. In vitro effects of calcium hydroxide and polymyxin $\mathrm{B}$ on endotoxins in root canals. J Dent 2005;33:107-14.

Olsson B, Sliwkowski A, Langeland K. Subcutaneous implantation for the biological evaluation of endodontic materials. J Endod 1981;7:355-67.

Onay EO, Ungor $\mathrm{M}$, Ozdemir BH. In vivo evaluation of the biocompatibility of a new resin-based obturation system. Oral Surg Oral Med Oral Pathol Oral Radiol Endod 2007;104:e60-6.

Onçag O, Cogulu D, Uzel A. Efficacy of various intracanal medicaments against Enterococcus faecalis in primary teeth: an in vivo study. J Clin Pediatr Dent 2006;30:233-7.

Onçag O, Hosgor M, Hilmioglu S, Zekioglu O, Eronat C, Burhanoglu D. Comparison of antibacterial and toxic effects of various root canal irrigants. Int Endod J 2003;36:42332.

O'Riordan MW, Coll J. Pulpectomy procedure for deciduous teeth with severe pulpal necrosis. J Am Dent Assoc 1979;99:480-4.

Ozalp N, Saroğlu I, Sönmez H. Evaluation of various root canal filling materials in primary molar pulpectomies: an in vivo study. Am J Dent 2005;18:347-50.

Ozbas $\mathrm{H}$, Yaltirik M, Bilgic B, Issever $\mathrm{H}$. Reactions of connective tissue to compomers, composite and amalgam root-end filling materials. Int Endod J 2003;36:281-7.

Payne RG, Kenny DJ, Johnston DH, Judd PL. Two-year outcome study of zinc oxideeugenol root canal treatment for vital primary teeth. J Can Dent Assoc 1993;59:528$30,533-6$.

Pazelli LC, Freitas AC, Ito IY, Souza-Gugelmin MC, Medeiros AS, Nelson-Filho P. Prevalence of microorganisms in root canals of human deciduous teeth with necrotic pulp and chronic periapical lesions. Pesqui Odontol Bras 2003;17:367-71.

Percinoto C. Terapia pulpar de dentes decíduos posteriores. In: $6^{\circ}$ Livro Anual do Grupo Brasileiro de Professores de Ortodontia e Odontopediatria. São Paulo: Image, 1997.

Pereira C da C, de Oliveira EP, Gomes MS, Della-Bona A, Vanni JR, Kopper PM, de Figueiredo JA. Comparative in vivo analysis of the sealing ability of three endodontic sealers in dog teeth after post-space preparation. Aust Endod J 2007;33:101-6. 
Podbielski A, Boeckh C, Haller B. Growth inhibitory activity of gutta-percha points containing root canal medications on common endodontic bacterial pathogens as determined by an optimized quantitative in vitro assay. J Endod 2000;26:398-403.

Primosch RE, Glomb TA, Jerrell RG. Primary tooth pulp therapy as taught in predoctoral pediatric dental programs in the United States. Pediatr Dent 1997;19:118-122.

Primosch RE, Ahmadi A, Setzer B, Guelmann M. A retrospective assessment of zinc oxide-eugenol pulpectomies in vital maxillary primary incisors successfully restored with composite resin crowns. Pediatr Dent 2005;27:470-7.

Puppin-Rontani RM, Peters CF, Worliczek AM. Tratamento endodôntico de dentes decíduos com necrose pulpar. Rev Assoc Paul Cir Dent 1994; 48:1235-8.

Rabêlo RTS. Penetrabilidade de diferentes pastas à base de hidróxido de cálcio na dentina radicular de dentes decíduos e permanentes : avaliação do pH e da liberação de íons cálcio. Dissertação. Ribeirão Preto: Faculdade de Odontologia-USP, 2003.

Ranly DM. Pulpotomy therapy in primary teeth: new modalities for old rationales. Pediatr Dent 1994;16:403-9.

Ranly DM, Garcia-Godoy F. Current and potential pulp therapies for primary and young permanent teeth. J Dent 2000;28:153-61.

Reader CM, Boniface M, Bujanda-Wagne S. Refractory endodontic lesion associated with Staphylococcus aureus. J Endod 1994;20:607-9.

Reddy S, Ramakrishna Y. Evaluation of antimicrobial efficacy of various root canal filling materials used in primary teeth: a microbiological study. J Clin Pediatr Dent 2007;31:193-8.

Ribeiro FC. Distribuição das bactérias nas estruturas mineralizadas dos dentes com necrose pulpar e granuloma apical. Dissertação. Bauru: Faculdade de Odontologia-USP, 1997.

Rietschel ET.; Brade H. Bacterial endotoxins. Scient Am 1992;267:54-61.

Rifkin A. A simple, effective, safe technique for the root canal treatment of abscessed primary teeth. J Dent Child 1980;47:435-41.

Rifkin A. The root canal treatment of abscessed primary teeth a three to four year follow-up. J Dent Child 1982;49:428-31.

Robke FJ. Effects of nursing bottle misuse on oral health: Prevalence of caries, tooth malalignments and malocclusions in north-German preschool children. J Orofac Orthop. 2008;69:5-19.

Rocha CT, Rossi MA, Leonardo MR, Rocha LB, Nelson-Filho P, Silva LA. Biofilm on the apical region of roots in primary teeth with vital and necrotic pulps with or without radiographically evident apical pathosis. Int Endod J 2008 May 10. [Epub ahead of print] 
Rodd HD, Waterhouse PJ, Fuks AB, Fayle SA, Moffat MA. British Society of Paediatric Dentistry. Pulp therapy for primary molars. Int J Paediatr Dent 2006;16 Suppl 1:15-23.

Rosendahl R, Weinert-Grodd A. Root canal treatment of primary molars with infected pulps using calcium hydroxide as a root canal filling. J Clin Pediat Dent 1995;19:255-8.

Roy PM, Harry P, Cailleux A, Allain P. Dangers of bismuth iodoform paraffin paste. Lancet 1994;344:1708.

Ruviére DB, Leonardo MR, da Silva LA, Ito IY, Nelson-Filho P. Assessment of the microbiota in root canals of human primary teeth by checkerboard DNA-DNA hybridization. J Dent Child (Chic) 2007;74:118-23.

Sadrian R, Coll JA. A long-term follow up on the retention rate of zinc oxide eugenol filler after primary tooth pulpectomy. Pediatr Dent 1993;15:249-253.

Santos EM. Análise da citotoxicidade in vitro de fármacos utilizados na terapia endodôntica de dentes decíduos. Estudo comparativo da ação da pasta Guedes-Pinto, formocresol, glutaraldeído e ácido fosfórico sobre cultura de fibroblastos. Dissertação. São Paulo: Faculdade de Odontologia-USP, 1998.

Santos EM. Ação da pasta Guedes-Pinto e do hidróxido de cálcio: avaliação histopatológica da reação do subcutâneo de ratos e da atividade quimiotática in vitro de macrófagos. Tese. São Paulo: Faculdade de Odontologia-USP, 2002.

Santos EM, Salim DA, Guedes-Pinto AC, Jaeger MMM. Analysis in vitro of cytotoxicity of pastes based on calcium hydroxide. J Dent Res 2000; (Abstracts) 79:1124.

Sari S, Okte Z. Success rate of Sealapex in root canal treatment for primary teeth: 3year

follow-up. Oral Surg Oral Med Oral Pathol Oral Radiol Endod 2008;105:e93-6.

Sarrami N, Pemberton MN, Thronhill MH, Theaker ED. Adverse reactions associated with the use of eugenol in dentistry. Br Dent J 2002;193:257-9.

Savioli RN, Pecora JD, Mian H, Ito IY. Evaluation of the antimicrobial activity of each component in Grossman's sealer. Braz Oral Res 2006;20:127-31.

Sawai J. Quantitative evaluation of antibacterial activities of metallic oxide powders ( $\mathrm{ZnO}, \mathrm{MgO}$ and $\mathrm{CaO}$ ) by conductimetric assay. J Microbiol Methods 2003;54:177-82.

Scheffer OL. Avaliação da possibilidade do preparo biomecânico dos condutos radiculares de molares decíduos. Dens 1973;5:147-53.

Schroder U. Effects of calcium hydroxide-containing pulp-capping agents on pulp cell migration, proliferation, and differentiation. J Dent Res 1985;64:541-8.

Segura JJ, Jiménez-Rubio A. Effect of eugenol on macrophage adhesion in vitro to plastic surfaces. Endod Dent Traumatol 1998;14:72-4. 
Seux D, Couble ML, Hartmann DJ, Gauthier JP, Magloire H. Odontoblast-like cytodifferentiation of human dental pulp cells in vitro in the presence of a calcium hydroxide-containing cement. Arch Oral Biol. 1991;36:117-28.

Shimizu T, Kawakami T, Ochiai T, Kurihara S, Hasegawa H. Histopathological evaluation of subcutaneous tissue reaction in mice to a calcium hydroxide paste developed for root canal fillings. J Int Med Res 2004;32:416-21.

Shovelton DS. The presence and distribution of microorganisms within non-vital teeth. Br Dent J 1964;117:101-7.

Silva LAB. Rizogênese incompleta: efeitos de diferentes pastas à base de hidróxido de cálcio na complementação radicular e na reparação periapical em dentes de cães Estudo histológico. Dissertação. Araraquara: Faculdade de Odontologia-UNESP, 1988.

Silva LAB, Leonardo MR. Qual a orientação para o tratamento endodôntico dos dentes decíduos? Rev Assoc Paul Cirurg Dent 1995;49:385.

Silva LAB, Leonardo MR, Faccioli LH, Figueiredo F. Inflammatory response to calcium hydroxide based root canal sealers. J Endod 1997;23:86-90. a

Silva LAB, Leonardo MR, da Silva RS, Assed S, Guimarães LF. Calcium hydroxide root canal sealers: evaluation of $\mathrm{pH}$, calcium ion concentration and conductivity. Int Endod J 1997 May;30:205-9. b

Silva LAB, Leonardo MR, Nelson-Filho P, Tanomaru JM. Comparison of rotary and manual instrumentation techniques on cleaning capacity and instrumentation time in deciduous molars. J Dent Child (Chic) 2004;71:45-7.

Silva LAB, Nelson-Filho P, Faria G, de Souza-Gugelmin MC, Ito IY. Bacterial profile in primary teeth with necrotic pulp and periapical lesions. Braz Dent J 2006;17:144-8.

Silva LAB, Nelson-Filho P, Leonardo MR, Rossi MA, Pansani CA. Effect of calcium hydroxide on bacterial endotoxin in vivo. J Endod 2002;28:94-8.

Silva RAB. Hidróxido de Cálcio associado à Clorexidina - Estudo em Cultura de Células (RAW 264.7 e Cultura Primária de Células da Linhagem Osteoblástica) e em Tecido Subcutâneo de Camundongos. Avaliação da Atividade Antimicrobiana. Tese. Ribeirão Preto: Faculdade de Odontologia-USP, 2007.

Sipert CR, Hussne RP, Nishiyama CK, Torres SA. In vitro antimicrobial activity of Fill Canal, Sealapex, Mineral Trioxide Aggregate, Portland cement and EndoRez. Int Endod ] 2005;38:539-43.

Smith JW, Leeb IJ, Torney DL. A comparison of calcium hydroxide and barium hydroxide as agents for inducing apical closure. J Endod 1984;10:64-70.

Sousa CJ, Loyola AM, Versiani MA, Biffi JC, Oliveira RP, Pascon EA. A comparative histological evaluation of the biocompatibility of materials used in apical surgery. Int Endod J. 2004;37:738-48. 
Sousa CJ, Montes CR, Pascon EA, Loyola AM, Versiani MA. Comparison of the intraosseous biocompatibility of AH Plus, EndoREZ, and Epiphany root canal sealers. J Endod 2006;32:656-62.

Souza PP, Aranha AM, Hebling J, Giro EM, Costa CA. In vitro cytotoxicity and in vivo biocompatibility of contemporary resin-modified glass-ionomer cements. Dent Mater. 2006;22:838-44.

Spedding RH. Root canal treatments for primary teeth. Dent Clin North Am 1973;17:105-24.

Spedding $\mathrm{RH}$. Incomplete resorption of resorbable zinc oxide root canal fillings in primary

teeth: report of two cases. ASDC J Dent Child 1985;52:214-6.

Srinivasan V, Patchett CL, Waterhouse PJ. Is there life after Buckley's Formocresol? Part I-a narrative review of alternative interventions and materials. Int J Paediatr Dent 2006;16:117-27.

Stanley HR. Pulpal consideration of adhesive materials. Oper Dent. 1992;Suppl 5:15164.

Stashenko P. The role of immune cytokines in the pathogenesis of periapical lesions. Endod Dent Traumatol 1990;6:89-96.

Stuart CH, Schwartz SA, Beeson TJ, Owatz CB. Enterococcus faecalis: its role in root canal treatment failure and current concepts in retreatment. J Endod 2006;32:93-8.

Sumer M, Muglali M, Bodrumlu E, Guvenc T. Reactions of connective tissue to amalgam, intermediate restorative material, mineral trioxide aggregate, and mineral trioxide aggregate mixed with chlorhexidine. J Endod 2006;32:1094-6.

Sundqvist G, Figdor D, Persson S, Sjögren U. Microbiologic analysis of teeth with failed endodontic treatment and the outcome of conservative re-treatment. Oral Surg Oral Med Oral Pathol Oral Radiol Endod. 1998;85:86-9

Sweet CA. Procedure for treatment of exposed and pulpless deciduous teeth. J Am Dent Assoc 1930;17:1150-3.

Tabrizizadeh M, Mohammadi Z. In vitro evaluation of antibacterial activities of root canal sealers. J Clin Dent. 2005;16(4):114-6.

Tagger E, Sarnat H. Root canal therapy of infected primary teeth. Acta Odontol Pediatr 1984;5:63-6.

Tanomaru JM, Leonardo MR, Tanomaru-Filho M, Bonetti Filho I, Silva LA. Effect of different irrigation solutions and calcium hydroxide on bacterial LPS. Int Endod J 2003;36:733-9.

Tanomaru-Filho M, Jorge EG, Guerreiro Tanomaru JM, Gonçalves M. Radiopacity evaluation of new root canal filling materials by digitalization of images $\mathrm{J}$ Endod 2007;33:249-51. a 
Tanomaru-Filho M, Tanomaru JM, Barros DB, Watanabe E, Ito IY. In vitro antimicrobial activity of endodontic sealers, MTA-based cements and Portland cement. J Oral Sci 2007;49:41-5. b

Tchaou WS, Turng BF, Minah GE, Coll JA. In vitro inhibition of bacteria from root canals of primary teeth by various dental materials. Pediatr Dent 1995;17:351-5.

Tchaou WS, Turng BF, Minah GE, Coll JA. Inhibition of pure cultures of oral bacteria by root canal filling materials. Pediatr Dent 1996;18:444-9.

Thomas AM, Chandra S, Chandra S, Pandey RK. Elimination of infection in pulpectomized deciduous teeth: a short-term study using iodoform paste. J Endod 1994;20:233-5.

Tobias RS. Antibacterial properties of dental restorative materials: a review. Int Endod ] 1988;21:155-60.

Toledo OA. Topografia canalicular dos dentes decíduos como contra-indicação do tratamento dos canais radiculares. Rev Assoc Paul Cirurg Dent 1961;15:24-8.

Torneck CD. Reaction of rat connective tissue to polyethylene tube implants. I. Oral Surg Oral Med Oral Pathol 1966;21:379-87.

Tosun G, Erdemir A, Eldeniz AU, Sermet U, Sener Y. Accuracy of two electronic apex locators in primary teeth with and without apical resorption: a laboratory study. Int Endod J 2008;41:436-41.

Tronstad L. Recent development in endodontic research. Scand J Dent Res 1992;100:52-9.

Tronstad L, Andreasen JO, Hasselgren G, Kristerson L, Riis I. pH changes in dental tissues after root canal filling with calcium hydroxide. J Endod 1981;7:17-21.

Tronstad L, Barnett F, Riso K, Slots J. Extraradicular endodontic infections. Endod Dent Traumatol 1987;3:86-90.

Vianna ME, Gomes BP, Sena NT, Zaia AA, Ferraz CC, Souza Filho FJ. In vitro evaluation of the susceptibility of endodontic pathogens to calcium hydroxide combined with different vehicles. Braz Dent J. 2005;16:175-80.

Walsh SE, Maillard JY, Russell AD, Catrenich CE, Charbonneau DL, Bartolo RG. Activity and mechanisms of action of selected biocidal agents on Gram-positive and -negative bacteria. J Appl Microbiol 2003;94:240-7.

Waterhouse PJ. Formocresol and alternative primary molar pulpotomy medicaments: a review. Endod Dent Traumatol 1995;11:157-62,

Willis-Owen SA, Flint J. The genetic basis of emotional behaviour in mice. Eur J Hum Genet 2006;14:721-8. 
Woods RL, Kildea PM, Gabriel SA, Freilich LS. A histologic comparison of Hydron and zinc oxide-eugenol as endodontic filling materials in the primary teeth of dogs. Oral Surg Oral Med Oral Pathol 1984;58:82-93.

Wright KJ, Barbosa SV, Araki K, Spångberg LS. In vitro antimicrobial and cytotoxic effects of Kri 1 paste and zinc oxide-eugenol used in primary tooth pulpectomies. Pediatr Dent. 1994;16:102-6.

Yacobi R, Kenny DJ, Judd P, Johnston DH. Envolving primary pulp therapy techniques. J Am Dent Assoc 1991;122:83-85.

Yamasaki M, Nakane A, Kumazawa M, Hashioka K, Horiba N, Nakamura H. Endotoxin and gram-negative bacteria in the rat periapical lesions. J Endod 1992;18:501-4.

Yaltirik $M$, Ozbas $H$, Bilgic $B$, Issever $H$. Reactions of connective tissue to mineral trioxide aggregate and amalgam. J Endod 2004;30:95-9.

Yesilsoy C, Koren LZ, Morse DR, Kobayashi C. A comparative tissue toxicity evaluation of established and newer root canal sealers. Oral Surg Oral Med Oral Pathol 1988;65:459-67.

Zafalon EJ, Versiani MA, de Souza CJ, Moura CC, Dechichi P. In vivo comparison of the biocompatibility of two root canal sealers implanted into the subcutaneous connective tissue of rats. Oral Surg Oral Med Oral Pathol Oral Radiol Endod 2007;103:e88-94.

Zanoni SEM. Efeito de "curativos de demora" à base de hidróxido de cálcio, sobre os tecidos apicais e periapicais de dentes de cães, após biopulpectomia. Análise histopatológica. Dissertação. Araraquara: Faculdade de Odontologia-UNESP, 1993.

Zelante A, Oliveira MRB, Lia RCC, Benatti Neto C. Compatibilidade biológica em tecido conjuntivo subcutâneo do rato, de pastas à base de hidróxido de cálcio contidas em tubos de dentina humana. Rev Odontol Unesp 1992; 21:37-46.

Zmener $\mathrm{O}$. Tissue response to a new methacrylate-based root canal sealer: preliminary observations in the subcutaneous connective tissue of rats. J Endod 2004;30(5):34851.

Zmener O, Banegas G, Pameijer $\mathrm{CH}$. Bone tissue response to a methacrylate-based endodontic sealer: a histological and histometric study. J Endod 2005;31:457-9.

Zmener O, Guglielmotti MB, Cabrini RL. Biocompatibility of two calcium hydroxidebased endodontic sealers: a quantitative study in the subcutaneous connective tissue of the rat. J Endod 1988;14:229-35.

Zmener O, Guglielmotti MB, Cabrini RL. Tissue response to an experimental calcium hydroxide-based endodontic sealer: a quantitative study in subcutaneous connective tissue of the rat. Endod Dent Traumatol 1990;6:66-72.

Zmener $\mathrm{O}$, Pameijer $\mathrm{CH}$. Clinical and radiographic evaluation of a resin-based root canal sealer. Am J Dent 2004;17:19-22. 


\section{Apêndices}


Apêndice A - Média e desvio padrão da área do tecido reacional granulomatoso (em um $^{2}$ )

\begin{tabular}{|c|c|c|c|c|c|c|}
\hline \multirow{2}{*}{ Materiais } & \multicolumn{2}{|c|}{7 dias } & \multicolumn{2}{|c|}{21 dias } & \multicolumn{2}{|c|}{63 dias } \\
\hline & Média & DP* & Média & DP* & Média & DP* \\
\hline EndoREZ $^{\mathrm{TM}}$ & 45,40 & 4,730 & 48,09 & 6,816 & 54,59 & 17,73 \\
\hline Sealapex ${ }^{\circledR}$ & 51,80 & 9,475 & 43,44 & 8,877 & 30,38 & 8,768 \\
\hline Óxido de zinco e eugenol & 61,30 & 11,17 & 45,33 & 10,15 & 51,85 & 11,32 \\
\hline
\end{tabular}

* DP = desvio padrão. 
Apêndice B - Média e desvio padrão da maior espessura do tecido reacional granulomatoso (em um)

\begin{tabular}{lllllll}
\hline \multicolumn{3}{c}{7 dias } & & 21 dias & & 63 dias \\
Materiais & \multicolumn{1}{c}{ Média } & DP* & Média & DP* & Média & DP* \\
\hline & 359,1 & 103,3 & 399,2 & 74,86 & 221,8 & 32,05 \\
Calen $^{\circledR}+$ óxido de zinco & 349,5 & 86,46 & 520,3 & 59,66 & 255,0 & 101,9 \\
EndoREZ $^{\text {TM }}$ & 298,0 & 87,47 & 325,9 & 79,58 & 171,5 & 52,56 \\
Sealapex & 354,7 & 138,2 & 390,0 & 44,71 & 235,2 & 57,61 \\
Óxido de zinco e eugenol & 353,3 & 4,314 & 216,6 & 75,72 & & \\
Controle & & & & & &
\end{tabular}


UNIVERSIDADE DE SAO PAULO COMISSAO OE ETICA

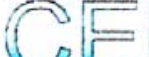

Co HO USO DE AHIBAIS

\section{UNIVERSIDADE DE SÃO PAULO}

Campus de Ribeirão Preto

Contissão de Ética no Uso de Animais

\section{E R T I F I C A D O}

Certificamos que 0 trabalho (Protocolo $n^{\circ}$ 07.1.124.53.0), intitulado: "Materiais Obturadores em Dentes Decíduos: Avaliaçäo da biocompatibilidade em tecido conjuntivo subcutâneo de camundongos isogênicos, cultura de células e dentes de cães", de autoria de Paulo Neison Filho, por estar de acordo com os Princípios Éticos na Experimentação Animal adotado pela Comissão de Ética no Uso de Animais (CEUA) do Campus de Ribeirão Preto - USP foi aprovado em reunião da CEUA de 08.05.07.

Ribeirão Preto, 11 de maio de 2007

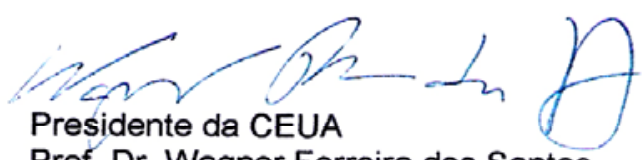

Prof. Dr. Wagner Ferreira dos Santos

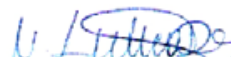

Secretária da CEUA

Maria Angélica Depiro 